\title{
WestVirginiaUniversity
}

THE RESEARCH REPOSITORY @ WVU

Graduate Theses, Dissertations, and Problem Reports

2005

\section{Evaluating real-world idle emissions from heavy-duty diesel vehicles}

ABM Siddiqur Rahman Khan

West Virginia University

Follow this and additional works at: https://researchrepository.wvu.edu/etd

\section{Recommended Citation}

Khan, ABM Siddiqur Rahman, "Evaluating real-world idle emissions from heavy-duty diesel vehicles" (2005). Graduate Theses, Dissertations, and Problem Reports. 4161.

https://researchrepository.wvu.edu/etd/4161

This Thesis is protected by copyright and/or related rights. It has been brought to you by the The Research Repository @ WVU with permission from the rights-holder(s). You are free to use this Thesis in any way that is permitted by the copyright and related rights legislation that applies to your use. For other uses you must obtain permission from the rights-holder(s) directly, unless additional rights are indicated by a Creative Commons license in the record and/ or on the work itself. This Thesis has been accepted for inclusion in WVU Graduate Theses, Dissertations, and Problem Reports collection by an authorized administrator of The Research Repository @ WVU. For more information, please contact researchrepository@mail.wvu.edu. 


\title{
Evaluating Real-World Idle Emissions from Heavy-Duty Diesel Vehicles
}

\author{
ABM Siddiqur Rahman Khan
}

Thesis submitted to the College of Engineering and Mineral Resources

At West Virginia University In Partial Fulfillment of the Requirements

For the degree of

\author{
Master of Science \\ In \\ Mechanical Engineering
}

Nigel N. Clark, Ph.D., Chair

W. Scott Wayne, Ph.D.

Andrei V. Smirnov, Ph.D.

Department of Mechanical and Aerospace Engineering

West Virginia University

Morgantown, West Virginia

2005 


\title{
ABSTRACT \\ Evaluating Real-World Idle Emissions from Heavy-Duty Diesel Vehicles
}

\begin{abstract}
ABM S. Khan
Long haul trucks in the USA idle for extended periods at truck stops and at pickup and drop-off points. The idling consumes fuel, contributes to engine wear and reduces atmospheric quality, but it cannot simply be proscribed because in many cases cab heat or air-conditioning provides essential driver comfort. As an example, there are nearly 1.5 million interstate trucks that operate in California, where climate control is essential. A comprehensive tailpipe emissions database to describe idling impacts is not available at present, although studies have been conducted to quantify idle emissions and to project the advantages of idle reduction technologies based on a few vehicles. This thesis presents one of the most complete data set available that may be used to quantify the impact of future idle reduction programs, and incorporates results from the West Virginia University transient test cell, the E-55/59 Study and the Gasoline-Diesel PM Split Study. The data have covered over sixty heavy-duty engines and trucks, with model years ranging from 1975 to 2004. Idle emissions data for regulated pollutants (CO, HC, NOx, and $\mathrm{PM}$ ) have been compiled and reported in grams per hour $(\mathrm{g} / \mathrm{hr})$. Idle $\mathrm{CO}_{2}$ emissions allowed the projection of fuel consumed, in units of gal/hr. These data were compared with existing data in the literature, while also researching the model year effects.

For the E-55/59 and the PM Split data, test-to-test variation was observed for repeat idle tests on the same vehicle, due to measurement variation, auxiliary loads, and ambient conditions. Idle emissions showed trends with engine model year, but substantial vehicleto-vehicle variation for vehicles with similar model years was also evident. For post-1990 vehicles, idle CO and PM emissions were found to decrease with increasing engine model year. The idle NOx emissions were, on average, higher after 1990 than before, which would correspond to the advent of electronic engine management and the advancing of timing to improve idle combustion. Vehicles with post 1990 engine model years were found to emit approximately $23 \mathrm{~g} / \mathrm{hr}$ of $\mathrm{CO}, 9 \mathrm{~g} / \mathrm{hr}$ of $\mathrm{HC}, 83 \mathrm{~g} / \mathrm{hr}$ of NOx, $1.4 \mathrm{~g} / \mathrm{hr}$ of $\mathrm{PM}$, and $4600 \mathrm{~g} / \mathrm{hr}$ of $\mathrm{CO}_{2}$ during idle, whereas vehicles with 1975 to 1990 model years were found to have on average $31 \mathrm{~g} / \mathrm{hr}$ of CO, $21 \mathrm{~g} / \mathrm{hr}$ of HC, $48 \mathrm{~g} / \mathrm{hr}$ of $\mathrm{NOx}, 4 \mathrm{~g} / \mathrm{hr}$ of PM, and $4500 \mathrm{~g} / \mathrm{hr}$ of $\mathrm{CO}_{2}$ idle emissions. No significant model year variations were observed for idle fuel consumption. Idle fuel consumption from the 19751990 model year and post 1990 model year vehicles was $0.46 \mathrm{gal} / \mathrm{hr}$ and $0.47 \mathrm{gal} / \mathrm{hr}$ respectively. Effects of air conditioning and elevated engine speed on idle emissions were also observed. Use of air conditioning increases emissions and fuel consumption by
\end{abstract}


$25 \%$ on average. However, $\mathrm{CO}_{2}$ and $\mathrm{NOx}$ emissions and fuel consumption increased by more than $150 \%$ except for PM and HC emissions, which increased by about $100 \%$ and $70 \%$ respectively when the engine speed was elevated from $600 \mathrm{rpm}$ to $1100 \mathrm{rpm}$. Two 2stroke diesel buses of MY 1982 and MY 1992 were tested during the PM Split Study and another bus (MY 2000) was recently tested during the Transit Vehicle Exhaust Emissions Evaluation Study. All emissions from the two 2-stroke diesel buses were higher than the MY 2000 bus except NOx, which was high for the MY 2000 bus.

In addition, idle emissions from the Transient mode of the Heavy Heavy-Duty Truck (HHDDT) Schedule were calculated and compared with the values obtained from idle cycles. Over the whole database, idle emissions from the Transient mode were higher than the emissions from the idle cycles except NOx, which was less than the NOx emissions obtained from the idle cycles. The high idle values of $\mathrm{CO}, \mathrm{HC}$, and $\mathrm{CO}_{2}$ from the Transient mode has been partly due to the effect of some accessory loadings such as fan and the compressors and partly due to the possible inclusion of emissions at initial acceleration while evaluating emissions from the continuous data. NOx emissions from the Transient mode were less than the NOx emissions obtained from the idle cycles, which could be attributed to the advance injection timing intentionally employed during idle.

Model years 1991, 1992, 1995, and 2000 DDC Series 60 engines in a test cell were found to consume fuel at only $70 \%$ of the level found in the PM Split and E-55/59 data. This is because fan and compressor loads were absent in the test cell. The test cell engines did exhibit CO and NOx emissions similar to the post-1990 vehicles, but emitted PM at about half of the level of the post-1990 vehicles. 


\section{ACKNOWLEDGEMENT}

I would like to take this unique opportunity to thank and salute my friend, philosopher and guide, Dr. Nigel Clark, George B. Berry Chair of Engineering and Professor, Department of Mechanical and Aerospace Engineering. I left behind my homeland, my job in Bangladesh Army, and all of my relatives, including my wife and my beloved daughter with an aim to pursue higher education in the United States, the Mecca of higher education and research. Since then I have been under his charming, caring, and friendly wings. I would also like to convey my special thanks to all professors of the Department of Mechanical and Aerospace Engineering including my advisors Dr. Andrei Smirnov and Dr. Scott Wayne and Graduate Program Director, Dr Jacky Prucz.

I take this opportunity to specially thank the sponsors of the projects E-55/59 and PM Split Study, namely; U.S. Department of Energy Office of FreedomCAR and Vehicle Technologies through the National Renewable Energy Laboratory, Coordinating Research Council Inc., California Air Resources Board, U.S. Environmental Protection Agency, the South Coast Air Quality Management District and the Engine Manufacturers Association. I am also grateful to all engineers and staffs of the Transportable Laboratories (Translab), who despite their busy schedule gave their valuable time to teach me every bits and bites on the operation of the Translab and its analyzers. Tom, Ryan, Andy, Byron, Tedd, and Curtis, thank you all. Finally, I would like to pay special tribute to my father, brothers, sisters, father-in-law, my wife and my little mum, Mariam. I am honored to dedicate this work to my mother, who always prayed the best for me. May Allah, the Almighty bless her departed soul. 


\section{TABLE OF CONTENTS}

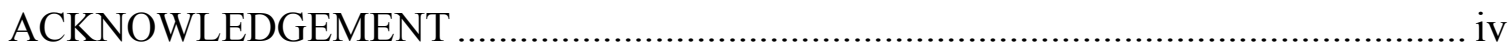

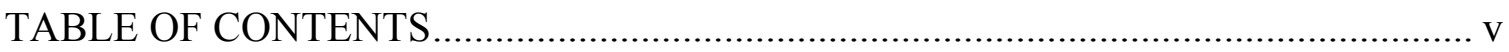

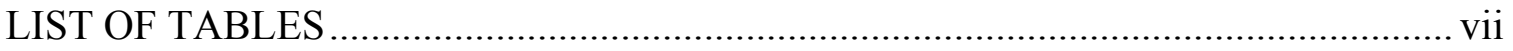

LIST OF FIGURES ................................................................................... viii

LIST OF ABBREVIATIONS AND SYMBOLS .................................................... xi

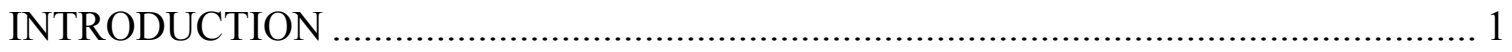

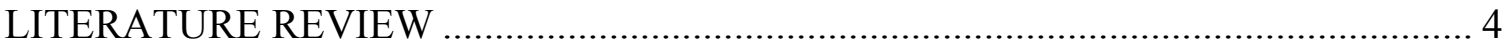

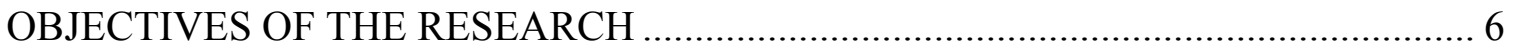

VEHICLES AND ENGINES MATRICES ........................................................ 8

TEST SITE, LABORATORY, AND SAMPLING ANALYSIS ................................... 12

Test Site and Test Duration .......................................................................... 12

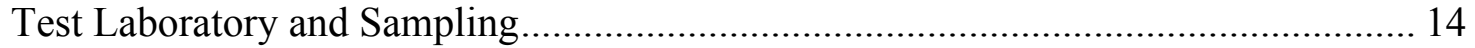

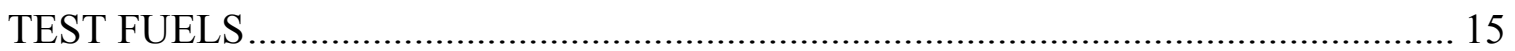

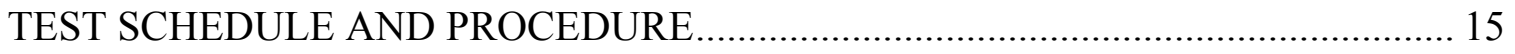

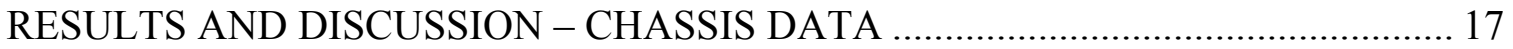

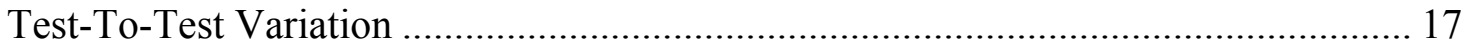

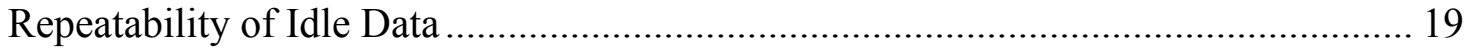

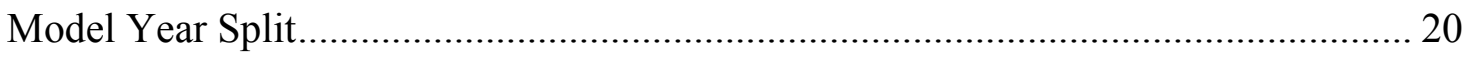

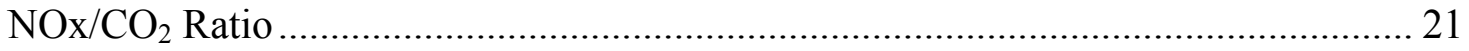

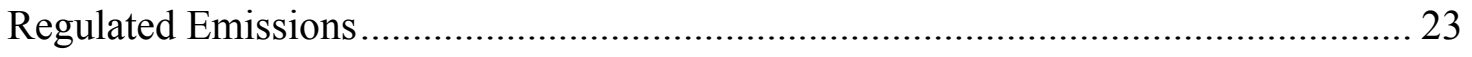

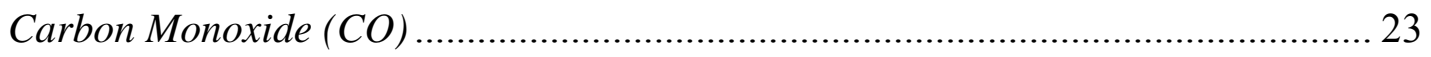

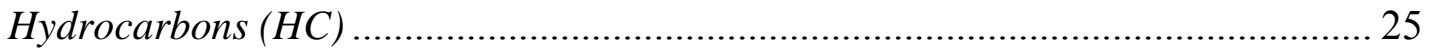


Oxides of Nitrogen (NOx) .............................................................................. 27

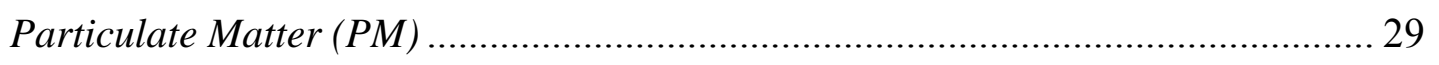

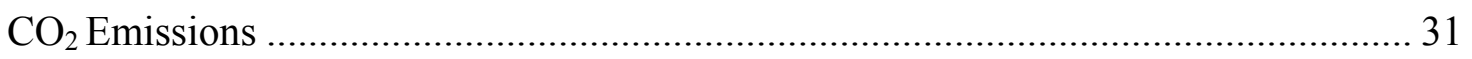

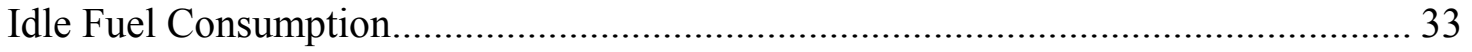

Effect of Air Conditioning and Idle Speed on Idle Emissions ..................................... 35

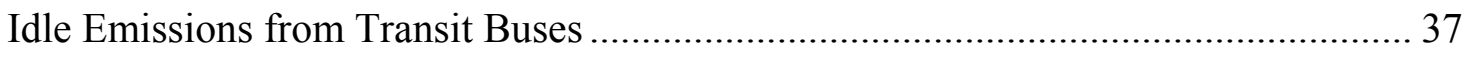

COMPARISON OF IDLE EMISSIONS FROM THE TRANSIENT MODE AND IDLE

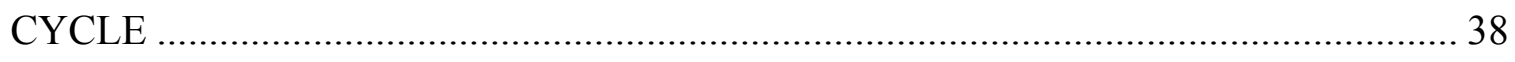

Evaluating Idle Emissions from Transient Mode of the HHDDT Schedule ................ 38

Comparing Idle Emissions Calculated from the Transient Mode with Measured Idle

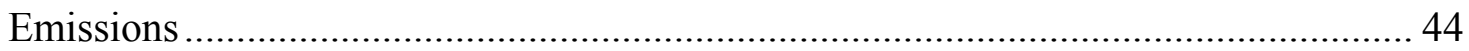

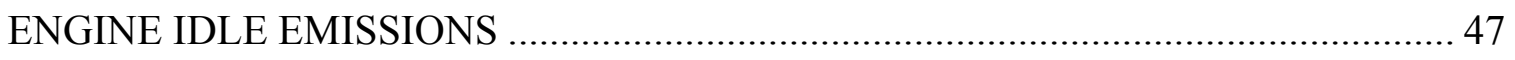

COMPARISON OF IDLE EMISSIONS MEASURED BY WVU WITH OTHER IDLE

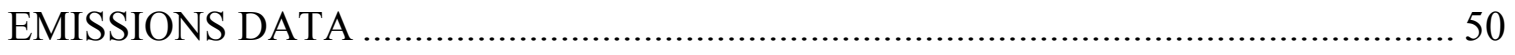

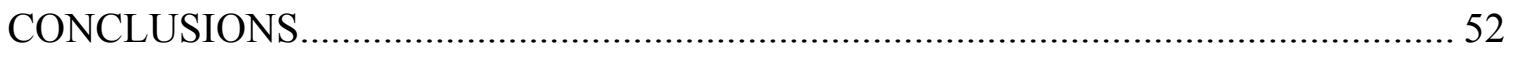

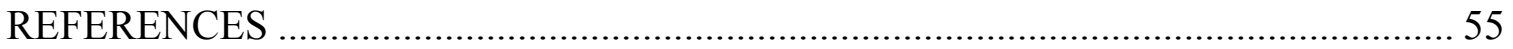




\section{LIST OF TABLES}

Table 1: Vehicles Tested for Acquiring Idle Data ....................................................... 8

Table 2: Comparison of Specified and Evaluated Properties of the CARB Specified

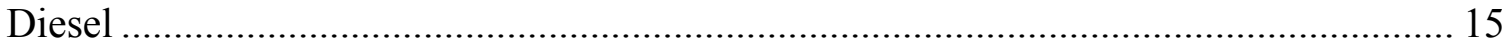

Table 3: Test-to-Test Variations in Emissions from CRC-7, CRC-19, and CRC-28 Trucks

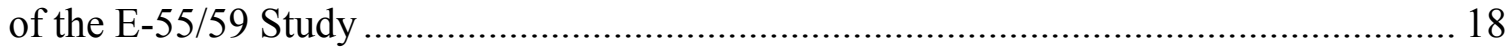

Table 4: Idle NOx/CO 2 Ratio from the E-55/59, PM Split Study and the NOx/CO $2 \ldots \ldots .21$

Table 5: Idle CO, $\mathrm{HC}$, NOx, and $\mathrm{CO}_{2}$ Emissions from the Transient Mode and Idle Cycle

Table 6: Type, Model Year, and Displacement of the Tested Engines .......................... 48

Table 7: Comparison of Engine and Tailpipe Idle Emissions, and Fuel Consumption from

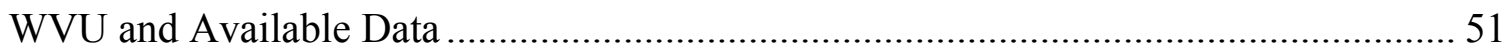




\section{LIST OF FIGURES}

Figure 1: Average annual high temperature of ten major cities across the USA............... 2

Figure 2: Average annual low temperature of ten major cities across the USA............... 2

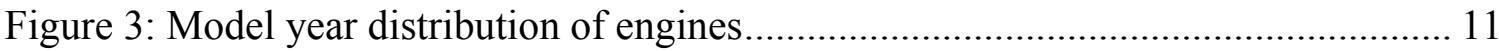

Figure 4: Monthly average high and low temperatures for Riverside, California ............ 13

Figure 5: Average annual relative humidity profile for Riverside, California ................ 13

Figure 6: Effect of idle duration on emissions ....................................................... 16

Figure 7: Average Idle emissions from CRC-7, CRC-19, and CRC-28 trucks of the E-

55/59 Study with Y-error bars showing \pm 1 standard deviations.

Figure 8: Repeatability of idle data. CRC-1, CRC-2, and CRC-3 truck of the E-55/59

Study were also tested during the PM Split Study as PM-33, PM-26 and PM-16

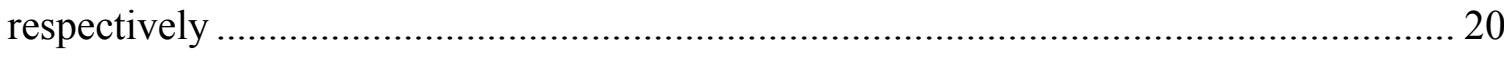

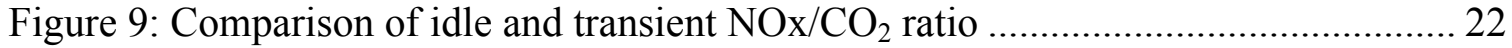

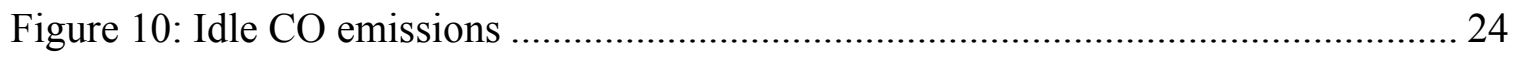

Figure 11: Idle CO emissions, excluding emissions from CRC-16, CRC-38, and CRC-45

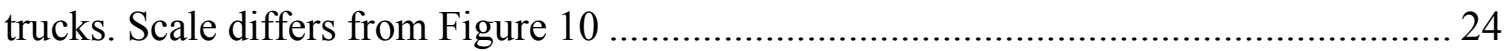

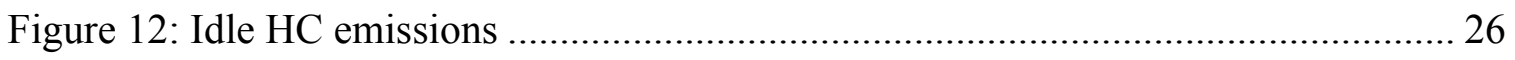

Figure 13: Idle $\mathrm{HC}$ emissions excluding emissions from $\mathrm{CRC}-16, \mathrm{CRC}-38$, and CRC-45

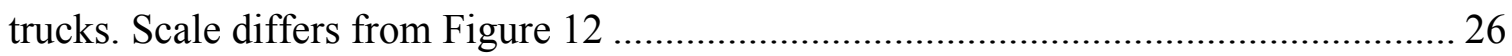

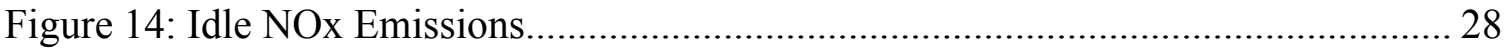

Figure 15: Idle NOx emissions excluding emissions from CRC-16, CRC-38 and CRC-45

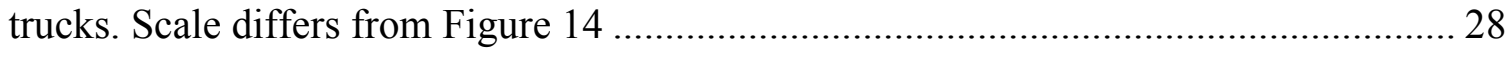

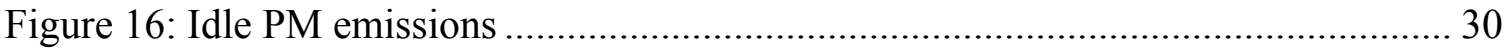


Figure 17: Modified idle PM emissions excluding emissions from CRC-16, CRC-38 and

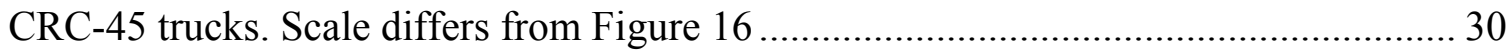

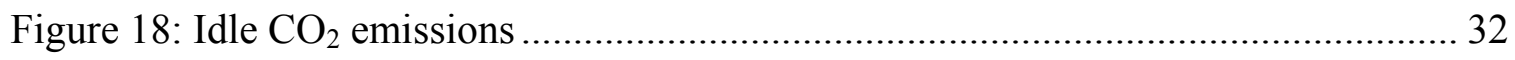

Figure 19: Idle $\mathrm{CO}_{2}$ emissions excluding emissions from $\mathrm{CRC}-16, \mathrm{CRC}-38$ and $\mathrm{CRC}-45$

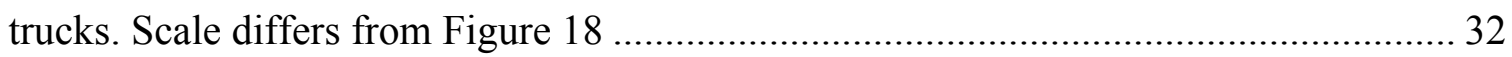

Figure 20: Idle fuel consumption in gallons per hour............................................. 34

Figure 21: Modified idle fuel consumption excluding CRC-16, CRC-38 and CRC-45

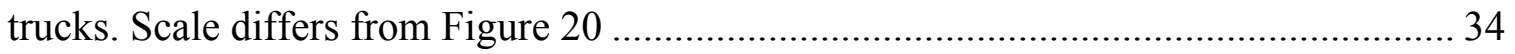

Figure 22: Effects of engine speed and air conditioning on idle emissions and fuel

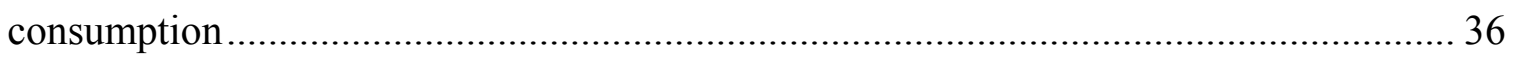

Figure 23: $\mathrm{CO}_{2}$ concentration over the idle mode with different engine accessories

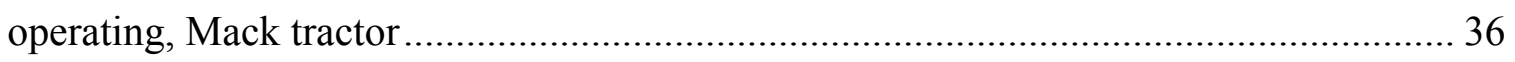

Figure 24: $\mathrm{NO}_{\mathrm{X}}$ concentration over the idle mode with different engine accessories

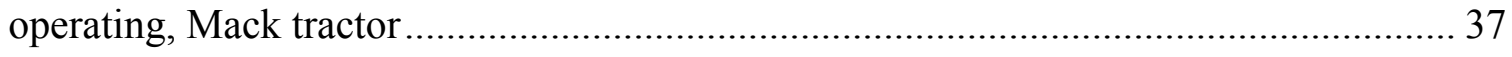

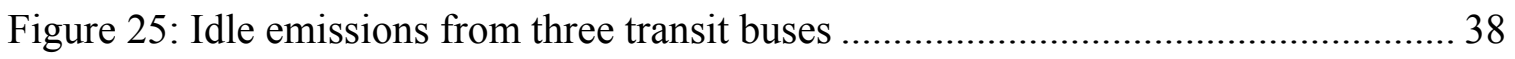

Figure 26: Transient mode of the HHDDT Schedule ................................................. 39

Figure 27: Continuous NOx emissions with respect to hub power (hp) for the .............. 40

Figure 28: Continuous NOx emissions with respect to hub speed (rpm) for the.............. 41

Figure 29: Continuous idle NOx emissions with respect to hub power. Hub power varied

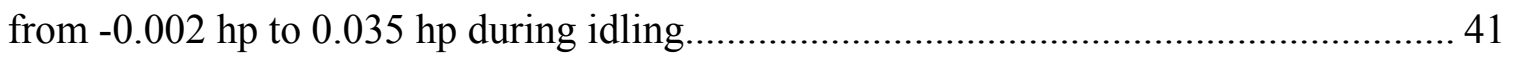

Figure 30: Continuous idle NOx emissions with respect to hub speed. Hub speed varied

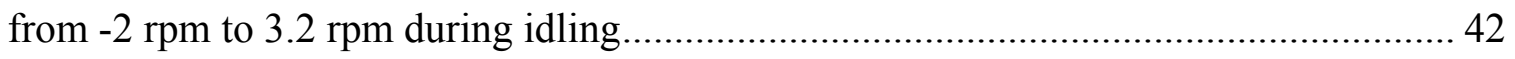


Figure 31: Variation of idle CO obtained from the Transient mode and values from the idle cycles with Engine MY

Figure 32: Variation of idle HC obtained from the Transient mode and values from the idle cycles with Engine MY. 46

Figure 33: Variation of idle NOx obtained from the Transient mode and values from the idle cycles with Engine MY. 46

Figure 34: Variation of idle $\mathrm{CO}_{2}$ obtained from the Transient mode and values from the idle cycles with Engine MY.....

Figure 35: Engine idle emissions from six DDC Series 60 Engines

Figure 36: Engine idle emissions including PM from Engine 2 50 


\section{LIST OF ABBREVIATIONS AND SYMBOLS}

$\mathrm{A} / \mathrm{C}$

APU

ANL

ATC

ATCM

CAFEE

CARB

CFR

CFV-CVS

$\mathrm{CN}$

$\mathrm{CNG}$

$\mathrm{CO}$

$\mathrm{CO}_{2}$

$\mathrm{COV}$

$\mathrm{CRC}$

DDC

DFH

DOE

DOT

EMFAC

FTP

${ }^{0} \mathrm{~F}$

GVW

$\mathrm{g} / \mathrm{gal}$

$\mathrm{g} / \mathrm{hr}$

HDDV

HFID

HHDDT

$\mathrm{HC}$ air conditioning

auxiliary power unit

Argonne National Laboratory

Aberdeen Test Center

Airborne Toxic Control Measure

Center for Alternative Fuels, Engines, and Emissions

California Air Resources Board

Code of Federal Regulations

critical flow venturi - constant volume sampling

Cetane Number

Compressed Natural Gas

carbon monoxide

carbon dioxide

coefficient of variance

Coordinating Research Council

Detroit Diesel Corporation

Direct-Fired Heater

Department of Energy

Department of Transportation

Emissions Facts

Federal Test Procedure

degrees of Fahrenheit

Gross Vehicle Weight

grams per gallon

grams per hour

Heavy-Duty Diesel Vehicles

heated flame ionization detector

Heavy Heavy-Duty Diesel Truck

hydrocarbons 


\begin{tabular}{ll} 
hp & horsepower \\
$\mathrm{Hz}$ & hertz \\
I\&M & Inspection and Maintenance \\
lbs & pounds \\
MY & model year \\
NOx & oxides of nitrogen \\
NREL & National Renewable Energy Laboratory \\
NDIR & non-dispersive infrared \\
ORNL & Oak Ridge National Laboratory \\
PM & particulate matter \\
\% & percentage \\
rpm & revolutions per minute \\
TEOM & Tapered Element Oscillating Microbalance \\
THC & total hydrocarbons \\
USEPA & United States Environmental Protection Agency \\
VMT & vehicle miles traveled \\
VOC & volatile organic compounds \\
vs. & Versus \\
WVU & West Virginia University \\
\hline
\end{tabular}




\section{INTRODUCTION}

National Energy Policy, 2001, while reiterating the importance of 'wise energy use', emphasized the need for reducing emissions and fuel consumption from long haul trucks at truck stops by implementing alternatives to idling [1]. Long haul trucks refer to Class 8 trucks with more than 33,000 pounds (lbs) Gross Vehicle Weight (GVW). The majorities of these trucks carry essentials across the country and stay overnight. Drivers of these trucks idle their engines for extended time during rest periods to ensure necessary cab heating or cooling, which cannot be proscribed because of the annual high and low temperature profile across the country that demands the use of heating and cooling for essential comfort. Figure 1 and Figure 2 show the average high and low temperature profile of ten major cities across the USA, which has been compiled from www.weather.com. Figures show that the average annual high temperature of these cities remains above $70^{\circ} \mathrm{F}$ from April to September except Seattle, while the average low temperature remains below $45^{\circ} \mathrm{F}$ from January to March and from October to December except Houston, Los Angeles, and Miami. Drivers also idle their engines in order to keep the engine warm, and to maintain battery voltage. Other reasons cited by the drivers include safety and habit [2].

There exists limited data on the extent and duration of idling from heavy-duty diesel vehicles (HDDV). Brodrick et al. [3] of the Institute of Transportation Studies, University of California, Davis, conducted a pilot survey on 233 line haul trucks in northern California but could not provide a conclusive figure on the extent of idling. The two extreme scenarios of idling duration from Class 7 and Class 8 vehicles ranged from 1000 hours per year to 5000 hours per year with 1830 hours per year considered a base case [4]. Another report estimates annual idling from long haul trucks could be between 1500 to 2400 hours [2]. This broad range implies seasonal effect, weather, and operation pattern of these vehicles. 


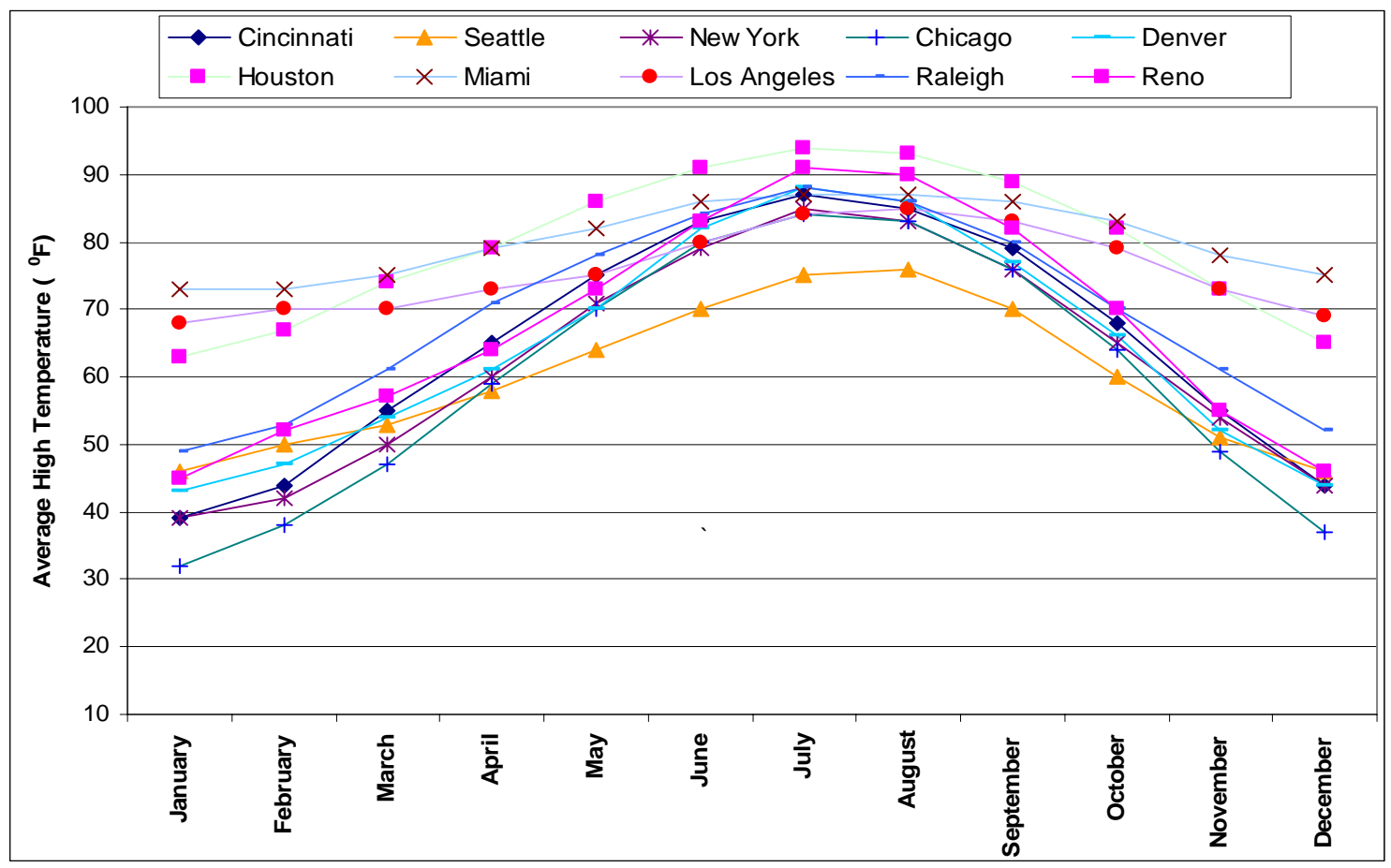

Figure 1: Average annual high temperature of ten major cities across the USA

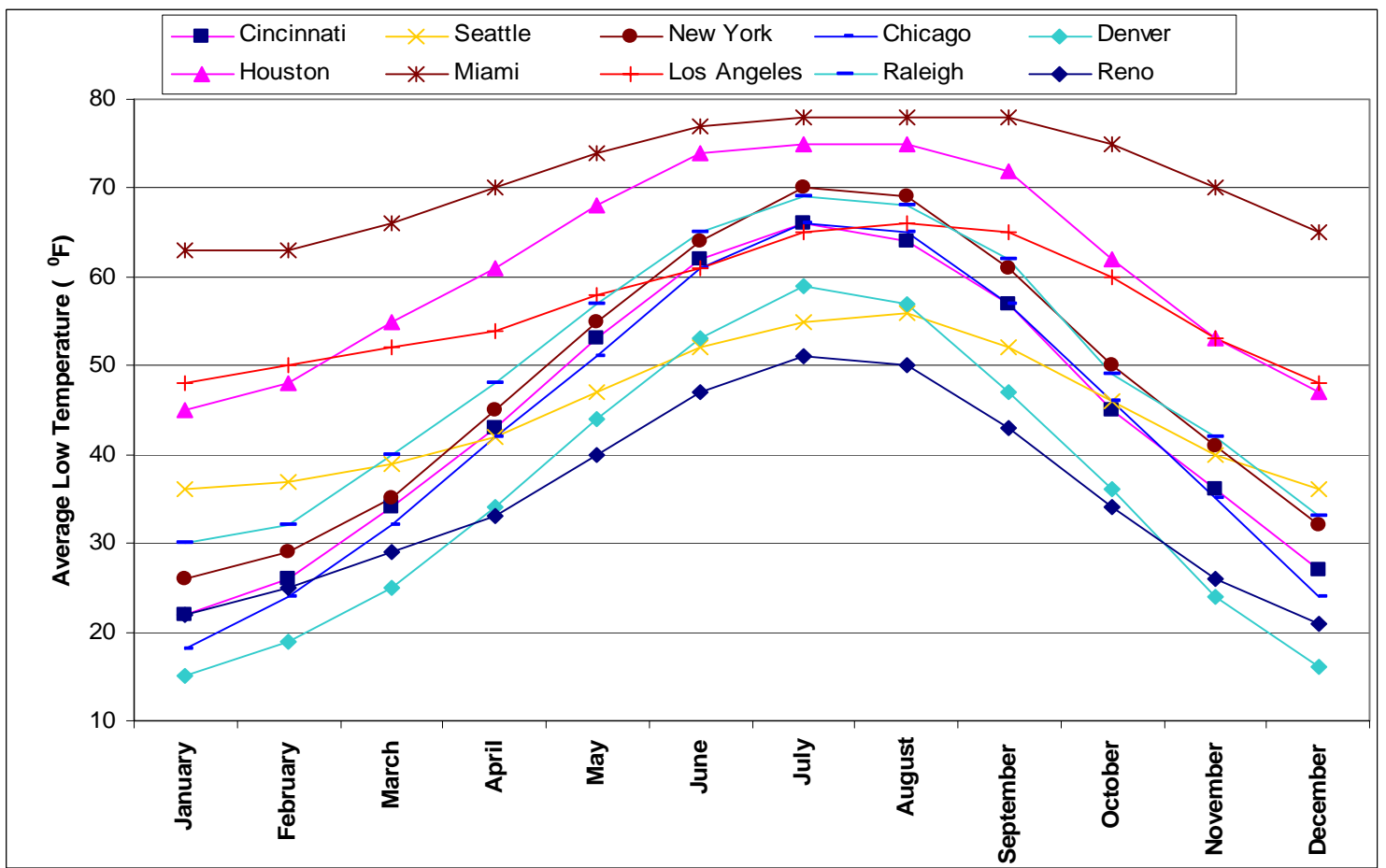

Figure 2: Average annual low temperature of ten major cities across the USA 
Extended idling from heavy-duty diesel trucks have economic, environmental, and health effects. These effects range from fuel wastage to significantly adding criteria pollutants to the ambient emissions inventory. It also increases annual repair and maintenance costs by generating more wear and tear on the engines. It would be unwise not to mention the noise pollution generated by idling of long haul trucks throughout the night. Taking into consideration the Argonne National Laboratory's (ANL) data [4] of 1.0-gallon diesel consumption per hour and considering the base case of annual idle duration, 1,500,000 long haul trucks in California consumed 2745 million gallons of diesel annually. This fuel wastage accounts for about 55 billion United States dollars (US\$) at present market price. In the same way it could be calculated that these long-haul trucks annually contribute about 28.5 million tons of carbon dioxide $\left(\mathrm{CO}_{2}\right), 155,000$ tons of oxides of nitrogen (NOx), 12,000 tons of hydrocarbons (HC), 260,000 tons of carbon monoxide (CO) and 7000 tons of particulate matter (PM) in California alone. In reality, these amounts could be larger because "calculations presented above" were made in a conservative framework considering the long haul trucks only. All these pollutants together contribute to global warming, formation of ozone smog and pose adverse health effects especially to children, elderly people and people with existing heart or respiratory diseases.

Realizing the extraordinary quantity of idling emissions and their adverse impacts, especially on overall fuel consumption, US federal and state environment organizations have initiated a number of steps in reducing these emissions. 'Anti-Idling Legislation' has been enacted in about 26 states across the United States with some legislation targeting specific urban areas and others with statewide restrictions. This restriction enforces limits on continuous idling from minimum two minutes to maximum fifteen minutes with the majority being five minutes [5]. Long-haul truck operators are also encouraged to use idle reduction technologies that would provide cab heating or cooling. In December 2002, The California Air Resources Board (CARB) adopted its first Antiidling Airborne Toxic Control Measure (ATCM) that would prohibit school buses and other diesel-fueled vehicles from idling within 100 feet of a school [6]. The CARB has also developed the 'Emissions Factors' (EMFAC) that tabulate idle emissions in grams 
per hour $(\mathrm{g} / \mathrm{hr}$ ) and grams per minute $(\mathrm{g} / \mathrm{min})$ for volatile organic compounds (VOC), $\mathrm{CO}$, and NOx for both summer and winter conditions. Idle emissions of particulate matter $\left(\mathrm{PM}_{10}\right)$ are tabulated only for $\mathrm{HDDV}(8501+\mathrm{lbs} \mathrm{GVW})$ as $\mathrm{PM}_{10}$ emissions from gasoline vehicles are considered to be negligible [7]. It is expected that all these steps would primarily reduce idle emissions of $\mathrm{NOx}, \mathrm{PM}, \mathrm{CO}, \mathrm{HC}$, and $\mathrm{CO}_{2}$, save millions of dollars in fuel and lower maintenance costs by reducing engine wear and tear.

\section{LITERATURE REVIEW}

A number of studies have been conducted recently to quantify idle emissions from the HDDV especially from long haul trucks to understand the effect of engine speed and accessory loading on idle emissions from these trucks and to evaluate the performance of idle reduction technologies. McCormick et al. [8] of the Colorado Institute for Fuels and Engines Research, Colorado School of Mines, Colorado performed a comprehensive study on idle emissions from twenty four HDDV (twelve trucks and twelve buses) and four heavy-duty Compressed Natural Gas (CNG) vehicles. Diesel trucks included ten Class 8 and Class 7 trucks, and one school bus whereas CNG vehicles included one medium-duty postal van and three transit buses. They considered hot and cold idle together as they did not find a significant difference between them. The study found that diesel trucks, on average, emitted $10.2 \mathrm{~g} / \mathrm{hr}$ of total hydrocarbons (THC), $70.98 \mathrm{~g} / \mathrm{hr}$ of $\mathrm{CO}, 84.96 \mathrm{~g} / \mathrm{hr}$ of NOx, and $1.8 \mathrm{~g} / \mathrm{hr}$ of PM of idle emissions, whereas CNG vehicles' idle emissions averaged $86.1 \mathrm{~g} / \mathrm{hr}$ of THC, $67.14 \mathrm{~g} / \mathrm{hr}$ of CO, $16.02 \mathrm{~g} / \mathrm{hr}$ of NOx, and $0.18 \mathrm{~g} / \mathrm{hr}$ of PM. The study could not portray altitude effect on idle emissions. However, the study revealed an increasing trend in idle NOx emissions with increasing engine model years (MY). Idle PM emissions exhibited a weaker trend with respect to engine MY and no significant MY trends were observed for CO or THC idle emissions. The study emphasized the need for additional data on a broader range of engine MY and vehicle types in order to explicitly observe MY trends on idling emissions.

Brodrick et al. [9] examined the effect of engine speed and accessory loading on heavyduty diesel truck's idle emissions. The study used U.S. Environmental Protection 
Agency's (USEPA) emission measurement trailers to quantify idle emissions from a 1999 model year Freightliner [450 horse power (hp) engine] in five idling modes namely idling after cruising, idling after transient cycle, low speed idling and high speed idling with air conditioning $(\mathrm{A} / \mathrm{C})$ on in both modes and long high speed idling with $\mathrm{A} / \mathrm{C}$ on. For all modes the idle emissions of $\mathrm{CO}, \mathrm{HC}, \mathrm{NOx}$, and $\mathrm{CO}_{2}$ ranged from 14.6 to 189.7 $\mathrm{g} / \mathrm{hr}, 1.4$ to $86.4 \mathrm{~g} / \mathrm{hr}, 103$ to $225 \mathrm{~g} / \mathrm{hr}$ and 4034 to $9743 \mathrm{~g} / \mathrm{hr}$ respectively. They also measured idle fuel consumption, which ranged from 0.36 to $0.93 \mathrm{gal} / \mathrm{hr}$. The study, however, did not measure idle PM emissions. The study revealed that engine speed and accessory loading significantly affected idle emissions. Increasing the engine speed from $600 \mathrm{rpm}$ to $1050 \mathrm{rpm}$ (with $\mathrm{A} / \mathrm{C}$ on in both cases) resulted corresponding increase in idle $\mathrm{CO}, \mathrm{NOx}$, and $\mathrm{CO}_{2}$ emissions by approximately $460 \%, 53 \%$ and $90 \%$ respectively. It also affected the fuel economy by almost $70 \%$.

Storey et al. [10] of the Oak Ridge National Laboratory (ORNL) examined CO, HC, $\mathrm{NOx}, \mathrm{CO}_{2}, \mathrm{PM}$, Aldehyde and Ketone emissions from heavy-duty trucks' exhausts at idle mode. Experimental testing on five Class 8 trucks were performed at the U.S. Army's Aberdeen Test Center (ATC)'s climate controlled chamber between June 2001 and May 2002. Trucks' model years ranged from 1992 to 2001. Out of these five trucks, one was equipped with auxiliary power unit (APU) and another was fitted with a diesel directfired heater (DFH). Trucks were tested at both high and low idle speeds in three following climate conditions: $90^{\circ} \mathrm{F}$ with cabin air conditioning on, $0^{0} \mathrm{~F}$ with cabin heater on, and $65^{\circ} \mathrm{F}$ with no accessories on. The approximate extreme values of idle emissions were found to be 50 to $350 \mathrm{~g} / \mathrm{hr}$ of NOx, 10 to $80 \mathrm{~g} / \mathrm{hr}$ of HC, 0.8 to $20 \mathrm{~g} / \mathrm{hr}$ of PM, and 22 to $295 \mathrm{~g} / \mathrm{hr}$ of CO. They also calculated fuel consumption, which ranged from 0.5 to $1.8 \mathrm{gal} / \mathrm{hr}$. The study found that emissions of these species increased with increasing idle speed. It also observed that ambient temperature affected PM emission and data showed that PM increased with increasing ambient temperature. Pekula et al. [11] of the Rowan University, College of Engineering, used the same data set to observe the effect of ambient temperature, humidity, and engine speed on idling emissions from heavy-duty diesel trucks. The study found that emissions rates were a function of both inlet 
temperature and engine load. Idle NOx and $\mathrm{CO}_{2}$ emissions for low and high idle speed were $97 \mathrm{~g} / \mathrm{hr}$ and $5170 \mathrm{~g} / \mathrm{hr}$ and $181.4 \mathrm{~g} / \mathrm{hr}$ and $11948 \mathrm{~g} / \mathrm{hr}$ respectively.

Some additional studies $[4,12]$ have also been conducted to analyze the potentials of various available and forthcoming idle reduction technologies in reducing idle emissions and saving fuel. These studies also focused on the market compatibility and cost benefit analysis of these technologies. The term "idle reduction technologies" refers to the technologies that allow engine operators to refrain from long-duration idling of the main propulsion engine by using alternative power sources [13]. The alternative power sources provide either heating or cooling or both to the drivers' cabin. Some of them also help in charging batteries and maintaining engine oil, coolant and fluids at the proper temperature for smooth starting of the engine. These technologies are classified into two broad categories: Mobile or on-road technology and stationary or off-road technology. Stationary or off-road technology has further been divided into two sub-groups basing on the requirements of components to operate them. The first category, Electrified Parking Spaces - Single System does not need any supporting system to be fitted on the trucks. Trucks will go to the parking spaces, fit the delivery module onto the cabin and enjoy heating, ventilation and air-conditioning. The second category, Electrified Parking Spaces - Dual System requires technology both on the truck and on the ground. Mobile or onroad technologies on the other hand are fitted on the vehicles or in-built on the engines and include automatic shut down/start up system, battery powered thermal control units, DFH, APU, generator sets etc. Mobile systems require greater financial commitment than stationary systems on the part of the truckers or the employers who buy those [14].

\section{OBJECTIVES OF THE RESEARCH}

This thesis aims to present a more generalized picture of idle emissions from a wide range of heavy-duty diesel trucks and buses in terms of model years and engine rated power. In addition to quantifying regulated emissions, $\mathrm{CO}_{2}$, and idle fuel consumption, this thesis would also observe the trends in idle emissions from vehicles with model years (MY) from 1975 to 2004. This thesis considers idle emissions data from forty-eight 
heavy-duty diesel trucks from the E-55/59 Study [15] and eighteen heavy-duty diesel vehicles including two diesel-driven transit buses from the Gasoline-Diesel PM Split Study [16]. E-55/59 Study was sponsored by the Coordinating Research Council (CRC), California Air Resources Board (CARB), U.S. Environmental Protection Agency (USEPA), U.S. Department of Energy (DOE) Office of FreedomCAR and Vehicle Technologies through the National Renewable Energy Laboratory (NREL), South Coast Air Quality Management District, and the Engine Manufacturers Association. This project had the major objective of acquiring regulated and non-regulated emissions from in-use trucks in Southern California. The Gasoline-Diesel PM Split Study was sponsored by the U.S. Department of Energy (DOE) Office of FreedomCAR and Vehicle Technologies through the NREL. The objective of this study was to collect reliable regulated PM data from broad spectrum of heavy-duty vehicles in Southern California. Idle emissions of regulated gases and $\mathrm{CO}_{2}$ and fuel consumption from all these vehicles were examined and reported in $\mathrm{g} / \mathrm{hr}$ and $\mathrm{gal} / \mathrm{hr}$ respectively. In addition, emissions from the idle segments of the continuous data on the 'Transient mode' of the Heavy HeavyDuty Diesel Truck (HHDDT) Schedule were evaluated for all trucks tested during the E55/59 study and compared with emissions from idle cycles. The thesis also examines the effect of elevated engine speed and accessory loadings including fan and the $\mathrm{A} / \mathrm{C}$ on idle emissions. In addition, idle emissions data from six Detroit Diesel Corporation (DDC) Series 60 engines of MY 1991, 1992, 1995, and 2000 tested for the fuel certification has also been considered for comparison. Finally a comparison of vehicle idle emissions obtained by the West Virginia University (WVU) and idle data available in the literature has been presented. Vehicle emissions data were collected by the WVU Transportable Emissions Measurement Laboratory (Translab) located at Riverside, California, whereas the engine emissions data were taken from the engine test cell of the Center for Alternative Fuels, Engines, and Emissions (CAFEE) of WVU located in Morgantown, West Virginia. 


\section{VEHICLES AND ENGINES MATRICES}

For this study data were procured from previous studies that examined emissions from sixty-six HDDV. Table 1 provides information on the actual vehicles recruited. Out of these vehicles, first forty-eight heavy-duty diesel vehicles' data were procured from the E-55/59 Study, in which the author participated. They included twelve DDC engines, thirteen Caterpillar, and twenty three Cummins engines. MY of these engines ranged from 1975 to 2004. However, for the first twenty-five trucks, vehicle MY has been taken as engine MY since engine MY of these trucks were not recorded when they were procured for emissions testing. The next eighteen heavy-duty trucks and buses' data were procured from the PM Split Study, where a total of thirty-two tractor/box trucks and two diesel buses were tested. This thesis takes into consideration the idle emissions of sixteen 'Class 8' trucks and two 'Class 7' trucks with GVW more than 32,000 lbs. They included one Volvo, three Cummins, five DDC, and seven Caterpillar engines. Two buses had DDC 6V92 model 2-stroke diesel engines. MY of all the engines from the PM Split Study ranged from 1982 to 2001. Interesting to note that three trucks in the E-55/59 Study (CRC-1, CRC-2, and CRC-3) were also procured for the PM Split study. These three trucks were designated as PM-33, PM-26, and PM-16 respectively. This repetition provided the opportunity to observe the repeatability of data generation from the same vehicle in two different studies.

Table 1: Vehicles Tested for Acquiring Idle Data

\begin{tabular}{|c|c|c|c|c|c|c|}
\hline Identification & $\begin{array}{c}\text { Vehicle } \\
\text { Model } \\
\text { Year }\end{array}$ & $\begin{array}{c}\text { Vehicle } \\
\text { Manufacturer }\end{array}$ & $\begin{array}{c}\text { Engine } \\
\text { Model } \\
\text { Year }\end{array}$ & Engine Model & $\begin{array}{c}\text { Engine } \\
\text { Power (hp) }\end{array}$ & $\begin{array}{c}\text { Engine } \\
\text { Manufacturer }\end{array}$ \\
\hline E55CRC-1 & 1994 & Freightliner & 1994 & Series 60 & 470 & Detroit \\
\hline E55CRC-2 & 1995 & Freightliner & 1995 & CAT3406 B & 375 & Caterpillar \\
\hline E55CRC-3 & 1985 & International & 1985 & NTCC & 300 & Cummins \\
\hline E55CRC-4 & 2000 & Navistar & 2000 & CAT C-10 & 270 & Caterpillar \\
\hline E55CRC-5 & 2000 & Freightliner & 2000 & N14-435E1 & 435 & Cummins \\
\hline
\end{tabular}




\begin{tabular}{|c|c|c|c|c|c|c|}
\hline E55CRC-6 & 1995 & Freightliner & 1995 & Cummins & 370 & Cummins \\
\hline E55CRC-7 & 1990 & Peterbilt & 1990 & Series 60 & 450 & Detroit \\
\hline E55CRC-8 & 1996 & Kenworth & 1996 & M11-300 & 370 & Cummins \\
\hline E55CRC-9 & 1998 & Peterbilt & 1998 & C 12 & 410 & Caterpillar \\
\hline E55CRC-10 & 1998 & Sterling & 1998 & Series 60 & 470 & Detroit \\
\hline E55CRC-11 & 2000 & Freightliner & 2000 & ISM & 330 & Cummins \\
\hline E55CRC-12 & 1986 & International & 1986 & Cummins & 300 & Cummins \\
\hline E55CRC-13 & 1978 & Freightliner & 1978 & Cummins & 350 & Cummins \\
\hline E55CRC-14 & 1986 & International & 1985 & LTA10 & 270 & Cummins \\
\hline E55CRC-15 & 1973 & Kenworth & 1986 & NTC & 350 & Cummins \\
\hline E55CRC-16 & 1979 & White & 1979 & CAT 3208 & 200 & Caterpillar \\
\hline E55CRC-17 & 1993 & Freightliner & 1993 & L-10 & 330 & Cummins \\
\hline E55CRC-18 & 1991 & Ford & 1991 & L-10 & 300 & Cummins \\
\hline E55CRC-19 & 1987 & International & 1987 & L-10 & 300 & Cummins \\
\hline E55CRC-20 & 1992 & Peterbilt & 1992 & Series 60 & 450 & Detroit \\
\hline E55CRC-21 & 1990 & Freightliner & 1990 & $3406 \mathrm{~B}$ & 400 & Caterpilla1 \\
\hline E55CRC-22 & 1993 & Ford & 1993 & $\mathrm{~L}-10$ & 280 & Cummins \\
\hline E55CRC-23 & 1983 & Peterbilt & 1983 & Cummins & N/A & Cummins \\
\hline E55CRC-24 & 1975 & Kenworth & 1975 & NTCC & 350 & Cummins \\
\hline E55CRC-25 & 1983 & Freightliner & 1983 & Cummins & N/A & Cummins \\
\hline E55CRC-26 & 1999 & Freightliner & 1998 & C-10 & 270 & Caterpillar \\
\hline E55CRC-27 & 2000 & Freightliner & 1999 & Series 60 & 500 & Detroit \\
\hline E55CRC-28 & 1999 & Freightliner & 1998 & Series 60 & 500 & Detroit \\
\hline E55CRC-29 & 2000 & Volvo & 1999 & ISX475ST2 & 450 & Cummins \\
\hline E55CRC-30 & 1999 & Freightliner & 1998 & Series 60 & 500 & Detroit \\
\hline E55CRC-31 & 1998 & Kenworth & 1997 & N14-460E+ & 460 & Cummins \\
\hline E55CRC-32 & 1992 & Volvo & 1991 & $3406 \mathrm{~B}$ & 280 & Caterpillar \\
\hline E55CRC-33 & 1985 & Freightliner & 1984 & 3406 & 310 & Caterpillar \\
\hline E55CRC-34 & 2004 & Freightliner & 2003 & Series 60 & 500 & Detroit \\
\hline E55CRC-35 & 2001 & Sterling & 2000 & Series 60 & 470 & Detroit \\
\hline E55CRC-36 & 2001 & Peterbilt & 2001 & C-15 & 475 & Caterpillar \\
\hline E55CRC-37 & 2004 & Volvo & 2004 & ISX & 500 & Cummins \\
\hline E55CRC-38 & 2003 & Volvo & 2004 & ISX & 530 & Cummins \\
\hline E55CRC-39 & 2004 & Volvo & 2003 & ISX & 530 & Cummins \\
\hline E55CRC-40 & 2004 & Freightliner & 2003 & Series 60 & 500 & Detroit \\
\hline E55CRC-42 & 2000 & Freightliner & 1999 & 3406 & 435 & Caterpillar \\
\hline
\end{tabular}




\begin{tabular}{|c|c|c|c|c|c|c|}
\hline E55CRC-43 & 1995 & Peterbilt & 1994 & Series 60 & 470 & Detroit \\
\hline E55CRC-44 & 1989 & Volvo GM & 1989 & 3406 & N/A & Caterpillar \\
\hline E55CRC-45 & 1993 & Volvo GM & 1993 & L10-280 & 280 & Cummins \\
\hline E55CRC-46 & 1989 & Freightliner & 1989 & 3176 & N/A & Caterpillar \\
\hline E55CRC-47 & 1986 & Ford & 1986 & $6 \mathrm{~V} 92$ & 350 & Detroit \\
\hline E55CRC-48 & 1998 & Freightliner & 1998 & N14 Plus & 447 & Cummins \\
\hline E55CRC-49 & 1994 & International & 1993 & N/A & N/A & Caterpillar \\
\hline PM-31* & 1982 & GMC & 1982 & $\begin{array}{c}\text { 6V92/8067- } \\
3421\end{array}$ & 340 & Detroit \\
\hline PM-17 & 1985 & Freightliner & 1985 & 3406 B & 350 & Caterpillar \\
\hline PM-16 & 1985 & International & 1985 & NTCC-300 & 300 & Cummins \\
\hline PM-18 & 1992 & Ford & 1992 & 3406 B & 280 & Caterpillar \\
\hline PM-20 & 1992 & Volvo & 1992 & $3406 \mathrm{~B}$ & 280 & Caterpillar \\
\hline PM-32* & 1992 & $\begin{array}{l}\text { Transportation } \\
\text { Manufacturer }\end{array}$ & 1992 & $\begin{array}{c}\text { 6V92/8067- } \\
3 \mathrm{~K} 21\end{array}$ & 270 & Detroit \\
\hline PM-19 & 1993 & Freightliner & 1993 & Series $60 \mathrm{C}$ & 350 & Detroit \\
\hline PM-21 & 1994 & Freightliner & 1994 & M11-330B & 330 & Cummins \\
\hline PM-25 & 1994 & Freightliner & 1994 & L14101 & 365 & Detroit \\
\hline PM-33 & 1994 & Freightliner & 1994 & Series 60 & 470 & Detroit \\
\hline PM-26 & 1995 & Freightliner & 1995 & $3406 \mathrm{~B}$ & 375 & Caterpillar \\
\hline PM-22 & 1996 & Volvo & 1996 & VE-D12 & 425 & Volvo \\
\hline PM-24 & 1997 & Ford & 1997 & Series 60 & 365 & Detroit \\
\hline PM-23 & 1997 & Volvo & 1997 & CAT 3406 & 435 & Caterpillar \\
\hline PM-30 & 1998 & Sterling & 1998 & Series 60 & 470 & Detroit \\
\hline PM-27 & 1999 & Sterling & 1999 & CAT C-12 & 425 & Caterpillar \\
\hline PM-29 & 2000 & Sterling & 2000 & CAT C-12 & 425 & Caterpillar \\
\hline PM-28 & 2001 & Volvo & 2001 & $2 \mathrm{~N} 14-370$ & 370 & Cummins \\
\hline
\end{tabular}

\section{* Transit bus}

While observing the trend in idle emissions with respect to MY, selection of vehicles over the period and number of vehicles in each MY year plays an important role. In the E-55/59 Study, efforts were made to procure vehicles for every MY to have an even distribution of vehicles over the MY. MY distributions of the vehicles from the E-55/59 and the PM Split Study are shown in Figure 3. The test matrices included only the 
heaviest class of on-road diesel vehicles of GVW 30,000 lbs and above as higher emissions rates are associated with heavy class of vehicles [17].

Emissions data obtained from the above vehicles were then compared with the engine idle emissions, which have been obtained by the CAFEE. A total of six DDC Series 60 engines of MY 1991, 1992, 1995, and 2000 were tested. Idle emissions data from these engines were collected and presented in $\mathrm{g} / \mathrm{hr}$. These engines were operated with Type 2-D diesel, Shell diesel, and CARB specified diesel. These engines were operated on the Federal Test procedure (FTP) cycle as per the test requirement from which the idle segments have been considered only in order to quantify idle emissions.

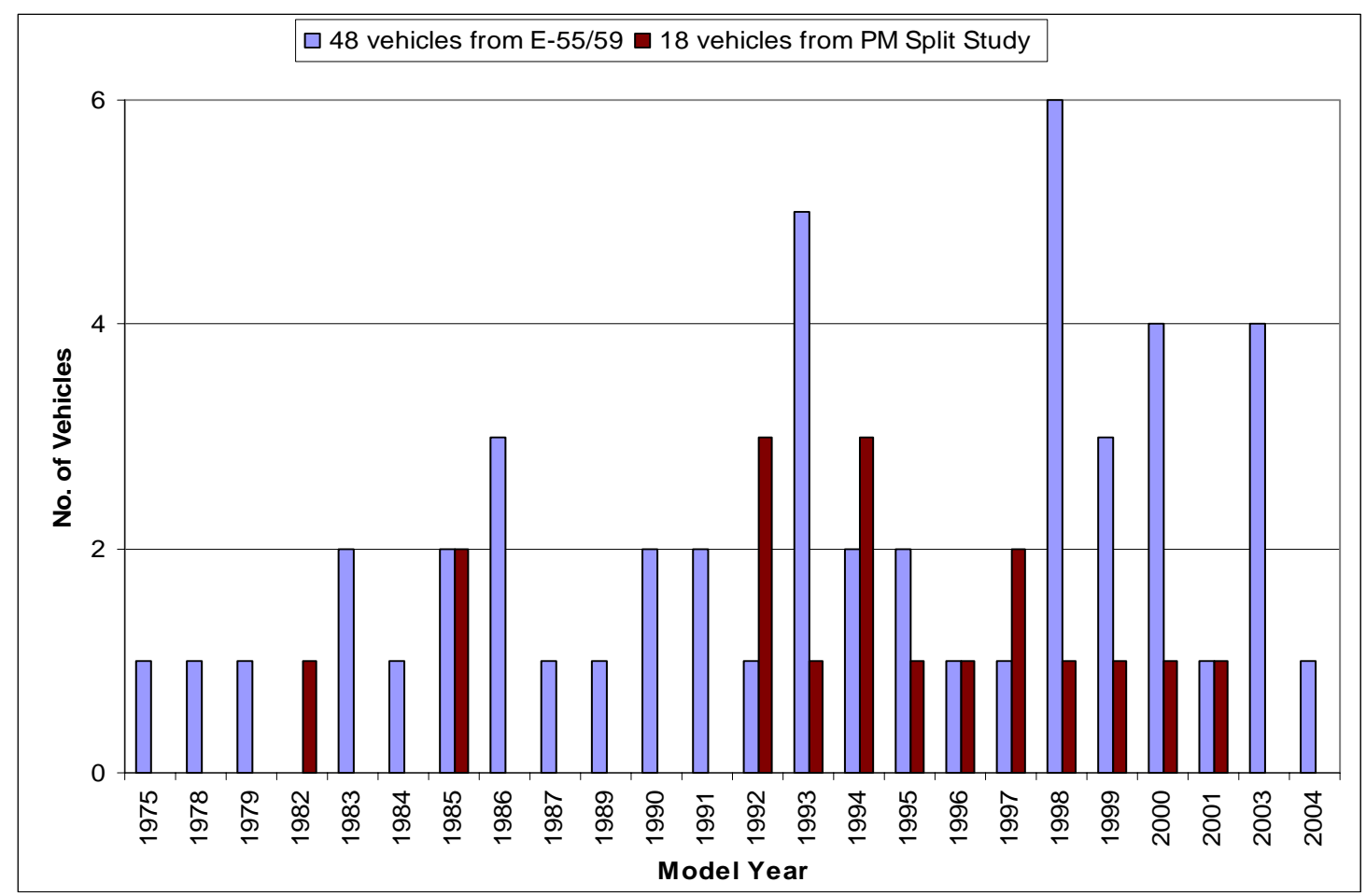

Figure 3: Model year distribution of engines 


\section{TEST SITE, LABORATORY, AND SAMPLING ANALYSIS}

\section{Test Site and Test Duration}

WVU Translab, while located on the West Coast (Riverside, California) was assigned to conduct emissions characterization from the vehicles listed in Table 1. Data for both the studies were collected over a long period from July 2001 to March 2004. Because of this long duration, some vehicles were tested during summer time when ambient temperatures were in the 90 s degree Fahrenheit $\left({ }^{0} \mathrm{~F}\right)$, whereas, some were tested during the winter time when ambient temperatures dropped to the lower $40 \mathrm{~s}\left({ }^{0} \mathrm{~F}\right)$ (Figure 4$)$. At the same time the relative humidity varied over this long duration, although variation of relative humidity was more profound from morning to afternoon. On average, there was $26 \%$ difference in the relative humidity from morning to afternoon (Figure 5). This wide variation in relative humidity and temperature was likely to affect idle emissions, especially NOx. Pekula et al. [11] observed a $15 \%$ to $20 \%$ decrease in idle NOx concentration when relative humidity increased by a factor of three. They also observed that NOx emissions had increased with increasing ambient temperatures. Figure 4 and Figure 5 show average annual relative humidity and average high and low temperature profiles of Riverside, California [18, 19]. 


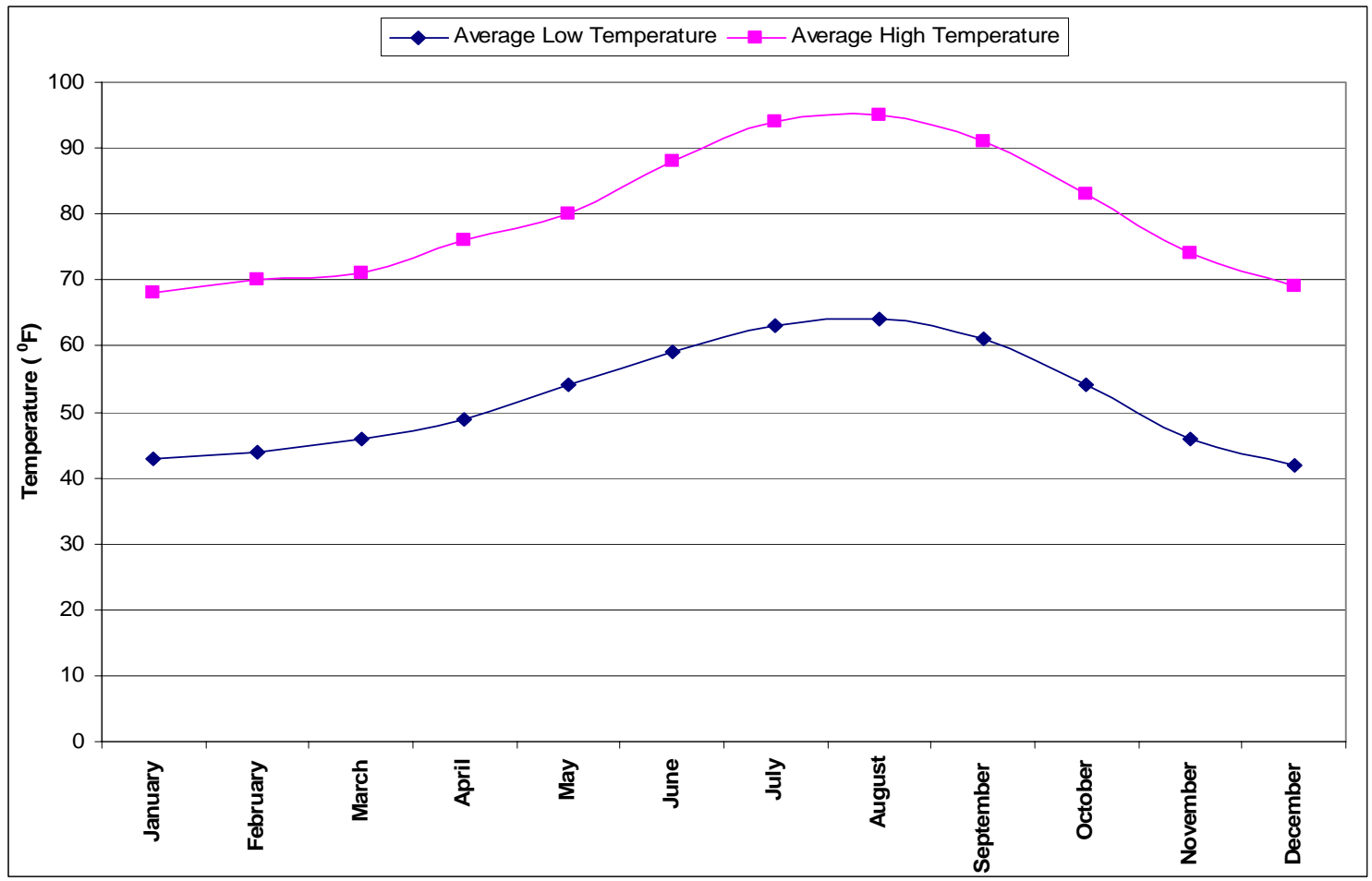

Figure 4: Monthly average high and low temperatures for Riverside, California

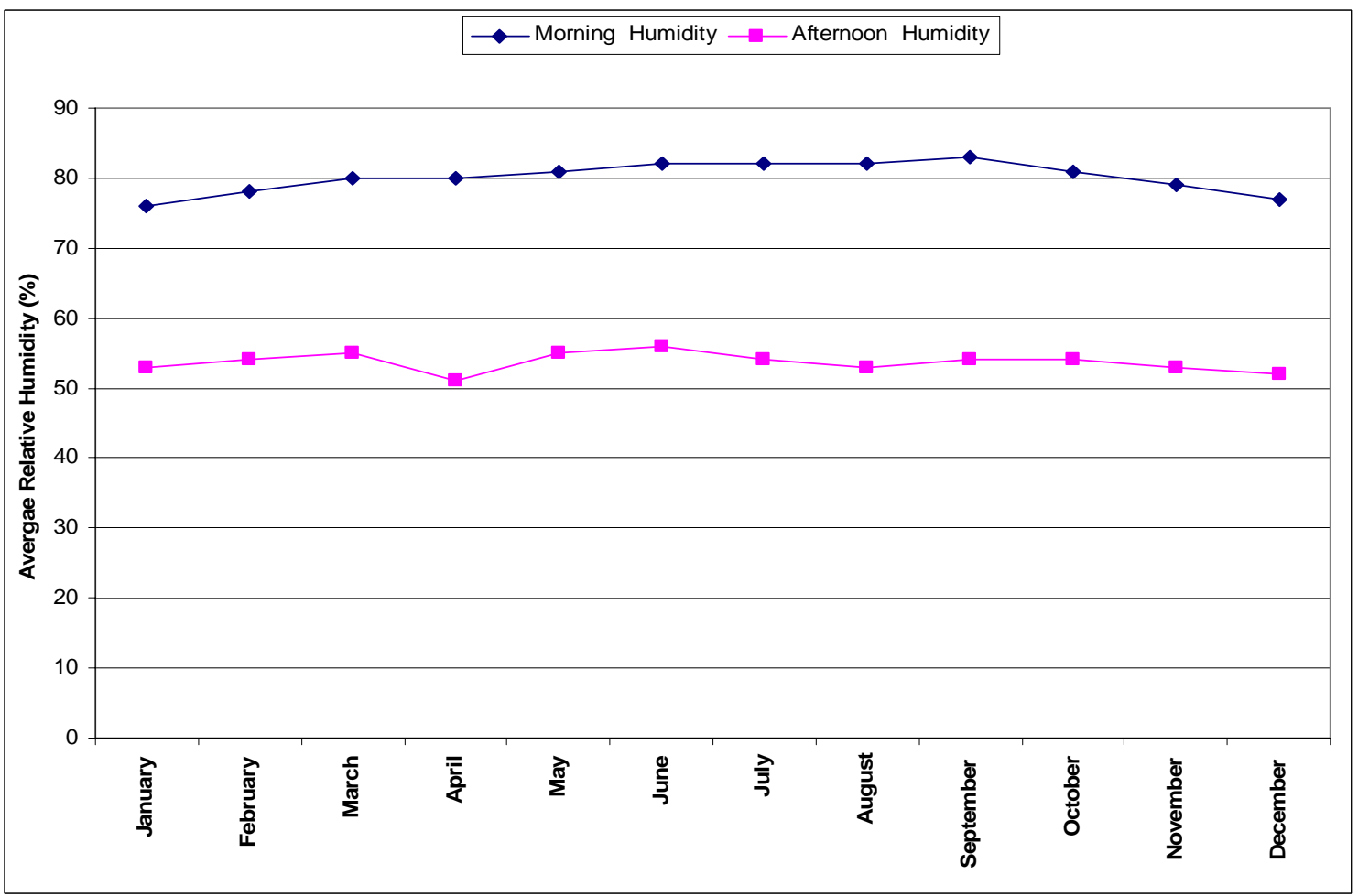

Figure 5: Average annual relative humidity profile for Riverside, California 


\section{Test Laboratory and Sampling}

All vehicles under the E-55/59 Study and the Gasoline/Diesel PM Split Study have been tested on the WVU Translab, while located at Riverside, California. The Translab was equipped with the state-of-the-art engine test equipment and was capable of testing medium and heavy-duty diesel vehicles. During idle, the vehicle was kept at idle for certain time with the engine speed kept at 600 revolutions per minute (rpm). For the Transient mode of the HHDDT Schedule, the driver operated the vehicle following the prescribed vehicle speed trace presented on a monitor, placed in front of him inside the cabin of the vehicle. The Translab had a full-scale exhaust dilution tunnel capable of measuring heavy-duty vehicles exhaust emissions in accordance with the Code of Federal Regulations (CFR) [20]. Idle exhaust was ducted to the dilution tunnel based on the critical flow venturi - constant volume sampling (CFV-CVS) concept. Microprocessor controlled heated probes and sampling lines were used to draw gaseous samples into the gas analyzers. Background samples and dynamic blanks were gathered for the correction of measured regulated emissions. Continuous sampling and analysis of the exhaust stream were accomplished by the non-dispersive infrared (NDIR) analyzers for CO and $\mathrm{CO}_{2}$; wet chemiluminescent analyzers for NOx; and a heated flame ionization detector (HFID) for HC. Data from the dynamometer, emissions measurement equipment and test engines were acquired and archived at a frequency of 5 hertz $(\mathrm{Hz})$. PM was sampled using two parallel filter-sampling trains. Continuous PM was measured using a Tapered Element Oscillating Microbalance (TEOM) and cycle-averaged PM was measured using filtration of diluted exhaust on two 70-mm fluorocarbon coated glass fiber filters. These filters were weighed before and after each test following proper conditioning. A detailed description of the WVU Translab can be found in two papers [21, 22]. Point to note that since the instruments were ranged for driving cycles, some accuracy might have been sacrificed at light load (idle). 


\section{TEST FUELS}

During the E-55/59 Study and the PM Split studies, vehicles tested for the idle emissions were operated with CARB specified diesel, which specifies a minimum 48 Cetane Number $(\mathrm{CN})$ and $0.05 \%$ sulfur (maximum) by weight. During the project period, some samples of CARB diesel were analyzed and detailed specifications were obtained. Table 2 compares laboratory analyzed average values of some salient properties and the prescribed properties for the CARB specified diesel [23].

Table 2: Comparison of Specified and Evaluated Properties of the CARB Specified

\section{Diesel}

\begin{tabular}{|c|c|c|c|}
\hline Fuel Property & Unit & CARB Specifications & CARB Measured Value \\
\hline Cetane Number & & $48(\min )$ & $52.9-54.4$ \\
\hline Sulfur & $\begin{array}{c}\% \\
\text { (weight) }\end{array}$ & $0.05(\max )$ & $0.0060-0.0148$ \\
\hline Aromatics & $\begin{array}{c}\% \\
\text { (volume) }\end{array}$ & $10(\max )$ & 19.82-21.49, Total Aromatics (by wt \%) \\
\hline Polycyclic Aromatics & $\begin{array}{c}\% \\
\text { (weight) }\end{array}$ & $1.4(\max )$ & $2.92-3.44$ \\
\hline API Gravity & & $33-39$ & $37.6-38.7$ \\
\hline Kinematic Viscosity @ $40^{\circ} \mathrm{C}$ & $\mathrm{mm}^{2} / \mathrm{s}$ & $2.0-4.1$ & $2.42-2.781$ \\
\hline Flashpoint & ${ }^{0} \mathrm{~F}$ & 130 (min) & $132-154$ \\
\hline Distillation Range & ${ }^{0} \mathrm{~F}$ & & \\
\hline $10 \%$ point & & $340-420$ & $386.1-415.5$ \\
\hline $50 \%$ point & & $400-490$ & $492.1-517.7$ \\
\hline $90 \%$ point & & $470-560$ & $611.2-626.9$ \\
\hline
\end{tabular}

\section{TEST SCHEDULE AND PROCEDURE}

As there cannot be any prescribed idle drive cycle, vehicles were idled for certain duration (seconds) to collect emissions data. These data has been analyzed and converted into $\mathrm{g} / \mathrm{hr}$. In the E-55/59 Study, vehicles were kept on idle for either 900 (Idle 3) or 1800 
(Idle 32) or 2700 (Idle 33) seconds, whereas in the PM Split Study, vehicles were idled for 1180 seconds, except one vehicle, which stopped idling after 1080 seconds. Average emissions from the short idle and long idle tests of CRC-2 truck (MY 1995 Freightliner) are presented in Figure 6. Y-error bars represent \pm 1 standard deviation for each pollutant. Difference in test schedule duration that is, the short idle (Idle 3) and long idle (idle 32) had mixed effect on emissions rates. $\mathrm{CO}, \mathrm{HC}, \mathrm{NOx}$, and $\mathrm{CO}_{2}$ varied little but PM showed greater variation. Therefore, average emissions from all idle tests were compiled for all vehicles over the entire database. Every vehicle and engine was tested at least two times on idle in order to get good repeatability of the test results. In case of variable repeatability the vehicle was tested again to get the repeatability within acceptable limit. All vehicles, except CRC-38 truck of the E-55/59 have been operated at constant engine speed of approximately $600 \mathrm{rpm}$ without any accessory loading. CRC-38 truck, in addition to two test runs at $600 \mathrm{rpm}$ engine speed was operated with $1100 \mathrm{rpm}$ engine speed and $\mathrm{A} / \mathrm{C}$ to observe the effect of elevated speed and $\mathrm{A} / \mathrm{C}$ on emissions and fuel consumption.

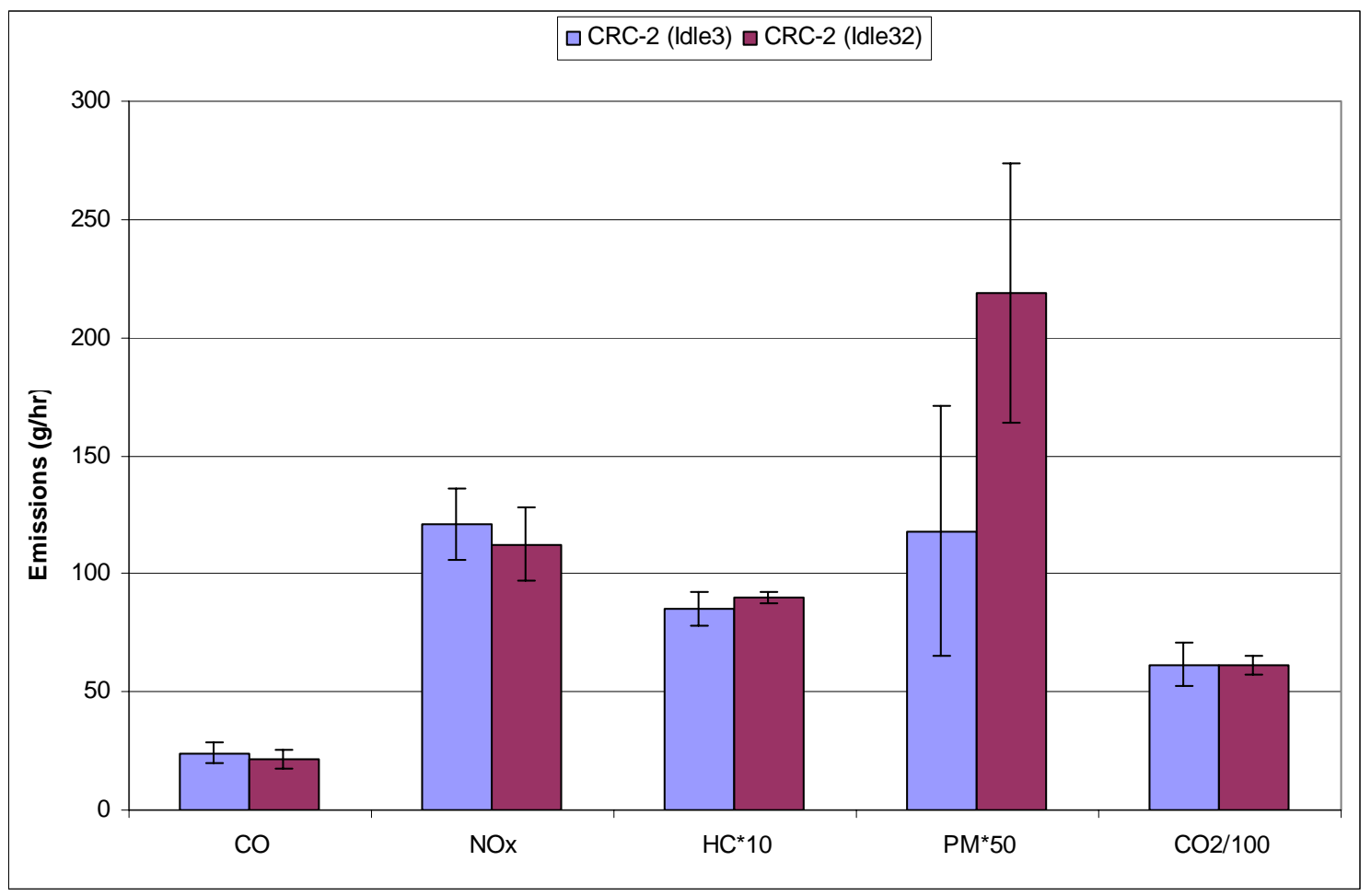

Figure 6: Effect of idle duration on emissions 


\section{RESULTS AND DISCUSSION - CHASSIS DATA}

This section begins with a discussion on test-to-test variations from all vehicles tested during the E-55/59 Study and the PM Split Study and their graphical presentation followed by a detailed discussion on the improvement in engine technology from 70 s to late 90s. MY effects on idle emissions were observed in two broad groups: MY 1975 to 1990 and MY 1991 to 2004, because of the difference in engine technology during these periods, which has been discussed in MY Split section. Idle CO, HC, NOx, and PM

emissions measured from tested vehicles are presented in the following sections. $\mathrm{CO}_{2}$ emissions, although not regulated by the USEPA have also been evaluated and presented in this study. In addition, idle fuel consumption inferred from the $\mathrm{CO}_{2}$ emissions for these vehicles was measured and presented in gal/hr. This section also makes an endeavor to observe the effect of air conditioning and elevated engine speed on idle emissions. Transit bus idle emissions are always of special interest because of their direct exposure to the community and therefore, have been presented in separate section.

\section{Test-To-Test Variation}

In order to observe the test-to-test variations during the testing, emissions data from three trucks E-55/59 CRC-7, CRC-19, and CRC-28 of MY 1990, 1987, and 1998 respectively have been presented. These three vehicles were tested five times on idle mode. Average emissions data with \pm 1 standard deviations and coefficient of variance (COV) are presented in Table 3. These data are also graphically presented in Figure 7 with Y-error bars showing the \pm 1 standard deviations. Higher standard deviations from these test results could be attributed to varying ambient conditions, differences in engine technology, and driver's driving pattern in maintaining idle speed of 600 rpm and different engine components such as the cooling fan, alternator, and air brake compressor [24]. NOx emissions on idle can also vary when electronic injection is used because the manufacturer may advance the timing at light load to maintain combustion stability and reduce PM containing high soluble organic fraction. Variability in the PM measurement 
could be attributed partly to the difficulty in measuring PM with filters lightly loaded, partly to the background corrections, and partly to the true variation between trucks because both injection timing and the condition of the injection system would affect the formation of PM. High variations in idle $\mathrm{CO}$ emissions could also be attributed to the variations in air-fuel ratio [17].

Table 3: Test-to-Test Variations in Emissions from CRC-7, CRC-19, and CRC-28 Trucks of the E-55/59 Study

\begin{tabular}{|c|c|c|c|c|c|c|c|c|c|c|}
\hline Vehicle & Pollutants & Test 1 & Test 2 & Test 3 & Test4 & Test 5 & Test 6 & Average & $\sigma$ & $\mathrm{COV}$ \\
\hline \multirow{5}{*}{$\begin{array}{c}C R C-7 \\
M Y{ }^{\prime} 90\end{array}$} & CO (g/hr) & 9.16 & 7.32 & 6.16 & 6.76 & 4.04 & 8 & 6.9 & 1.75 & 25.30 \\
\hline & NOx $(\mathrm{g} / \mathrm{hr}) / 10$ & 8.2 & 7.14 & 7.16 & 6.64 & 9.56 & 9.84 & 8.09 & 1.35 & 16.68 \\
\hline & THC (g/hr) & 3.64 & 2.22 & 2.12 & 1.48 & 3.24 & 3.8 & 2.75 & 0.94 & 34.21 \\
\hline & $P M(g / h r) * 10$ & 0 & 0 & 0.4 & 1.6 & 4 & 2 & 1.33 & 1.55 & 116.74 \\
\hline & $\mathrm{CO}_{2}(\mathrm{~g} / \mathrm{hr}) / 100$ & 40 & 31.38 & 32 & 28.8 & 39.08 & 41.04 & 35.38 & 5.25 & 14.84 \\
\hline \multirow{5}{*}{$\begin{array}{l}\text { CRC -19 } \\
\text { MY '87 }\end{array}$} & $\mathrm{CO}(\mathrm{g} / \mathrm{hr})$ & 30.4 & 40.4 & 34 & 33.2 & 59.6 & 59.2 & 42.8 & 13.27 & 31.00 \\
\hline & NOx $(\mathrm{g} / \mathrm{hr}) / 10$ & 2.92 & 2.68 & 0.8 & 1.92 & 1.52 & 1.52 & 1.89 & 0.79 & 41.98 \\
\hline & THC (g/hr) & 29.2 & 34.4 & 16.8 & 27.2 & 41.2 & 30 & 29.8 & 8.09 & 27.15 \\
\hline & $\mathrm{PM}(\mathrm{g} / \mathrm{hr})^{*} 10$ & 51.2 & 56.8 & 68.4 & 55.2 & 84.8 & 91.2 & 67.93 & 16.69 & 24.56 \\
\hline & $\mathrm{CO}_{2}(\mathrm{~g} / \mathrm{hr}) / 100$ & 43.92 & 44.4 & 28.92 & 37.44 & 38.88 & 35.88 & 38.24 & 5.72 & 14.96 \\
\hline \multirow{5}{*}{$\begin{array}{c}C R C-28 \\
M Y ' 98\end{array}$} & CO (g/hr) & 35 & 35.4 & 23.4 & 30.4 & 28.6 & 26.2 & 29.83 & 4.78 & 16.02 \\
\hline & NOx $(g / h r) / 10$ & 8.68 & 8.2 & 9.14 & 13.56 & 15.76 & 12.36 & 11.28 & 3.07 & 27.26 \\
\hline & THC (g/hr) & 3.8 & 2.42 & 2.42 & 1.06 & 2.18 & 0 & 1.98 & 1.30 & 65.88 \\
\hline & $P M(g / h r) * 10$ & 6.8 & 5.8 & 6 & 3.8 & 5.2 & 4.6 & 5.37 & 1.07 & 19.91 \\
\hline & $\mathrm{CO}_{2}(\mathrm{~g} / \mathrm{hr}) / 100$ & 38.88 & 35.22 & 34.4 & 42.08 & 47.6 & 44.46 & 40.44 & 5.22 & 12.91 \\
\hline
\end{tabular}




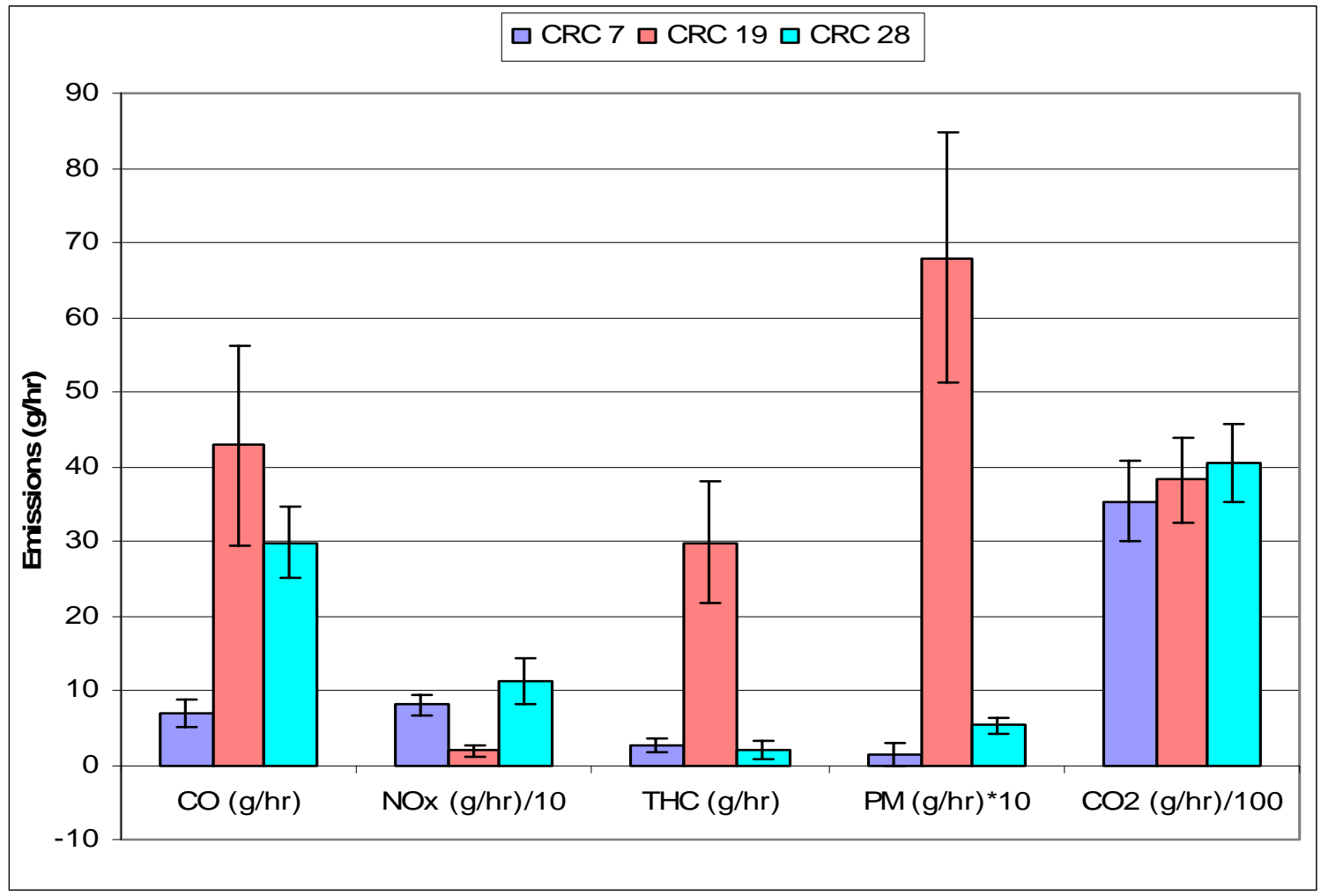

Figure 7: Average Idle emissions from CRC-7, CRC-19, and CRC-28 trucks of the

E-55/59 Study with Y-error bars showing \pm 1 standard deviations

\section{Repeatability of Idle Data}

Three vehicles from the E-55/59 Study had also been tested on idle on the PM Split Study. CRC-1, CRC-2, and CRC-3 trucks from the E-55/59 refer to PM-33, PM-26, and PM-16 trucks of the PM Split Study respectively. During the E-55/59 Study, these trucks were tested on idle for a number of runs while they were tested for one idle test run under the PM Split Study. Average idle emissions from the E-55/59 have been compared to the idle values obtained from the PM Split Study and presented in Figure 8. The first two trucks showed little variation in $\mathrm{CO}, \mathrm{NOx}$, and $\mathrm{HC}$ emissions. On the second truck $\mathrm{CO}_{2}$ decreased by about $20 \%$ while PM increased by about $50 \%$ when the truck was tested for the E-55/59. On the third truck PM decreased by about 30\% while $\mathrm{CO}_{2}$ decreased by 55\% when tested during the E-55/59 Study. 


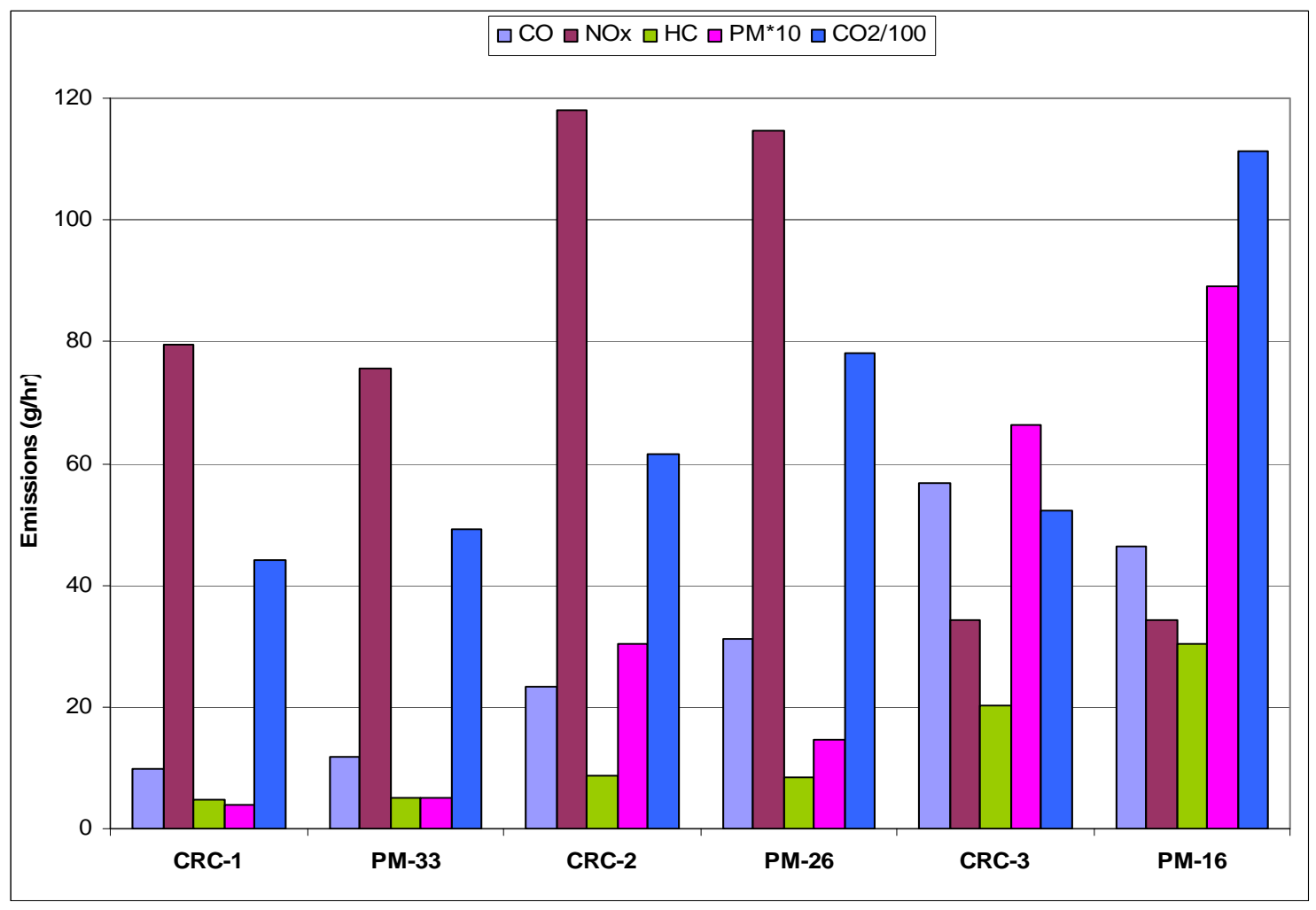

Figure 8: Repeatability of idle data. CRC-1, CRC-2, and CRC-3 truck of the E55/59 Study were also tested during the PM Split Study as PM-33, PM-26 and PM16 respectively

\section{Model Year Split}

Idle emissions trends were observed by observing emissions into two distinct groups: vehicles with MY 1975-1990 and MY 1991-2004 because, the automobile industry has gone through many remarkable changes during the 90 s partly due to the enforcement of stricter emissions regulations and partly due to the outstanding advancements in this field. These changes together contributed to lower emissions of some of the criteria pollutants, more engine power, and improved fuel economy because of efficient combustion and electronic fuel injection. It has been observed that the majority of the vehicles with MY 1975-1990 had mechanically managed engines, whereas the majority of the vehicles with MY 1991-2004 had electronically managed engines. Electronically managed engines have advanced timing at low loads to avoid 'white smoking'. Advanced timing increases the cylinder temperature and more NOx is generated [25]. It would be 
unwise not to mention the contribution of other developments such as injection rate shaping, low sac cooling, charge motion, superior fuel atomization, and reduced engine oil consumption. Superior fuel atomization and air management, charge motion, reduced engine oil consumption decreases PM production for later MY vehicles. Therefore, observing the trends in emissions in pre 1990 (1975-1990) MY and post 1990 MY will provide effective comparison in emissions characteristics from these groups of vehicles.

\section{$\mathrm{NOx} / \mathrm{CO}_{2}$ Ratio}

In order to observe the immediate difference between pre 1990 (1975-1990) and post $1990 \mathrm{MY}, \mathrm{NOx} / \mathrm{CO}_{2}$ ratios from both the Transient mode of the HHDDT Schedule and idle cycles were observed. $\mathrm{NOx} / \mathrm{CO}_{2}$ ratio is an indicator of advance injection timing, which has been employed by the engine manufacturers in the $90 \mathrm{~s}$ in order to ensure complete and stable combustion. It is also an indicator of how much emissions are released per unit of fuel consumption since fuel consumption is calculated from $\mathrm{CO}_{2}$ emissions. Table 4 compiles the summery of idle $\mathrm{NOx} / \mathrm{CO}_{2}$ ratio from the E-55/59 and the PM Split Study and the Transient $\mathrm{NOx} / \mathrm{CO}_{2}$ ratio from the Transient mode of the E$55 / 59$ only.

\section{Table 4: Idle NOx/ $/ \mathrm{CO}_{2}$ Ratio from the E-55/59, PM Split Study and the $\mathrm{NOx} / \mathrm{CO}_{2}$ Ratio from the Transient Mode}

\begin{tabular}{|c|c|c|}
\hline $\mathrm{NOx} / \mathrm{CO}_{2}$ Ratio & MY 1975-1990 & MY 1991-2004 \\
\hline E-55/59 Study & 0.0104 & 0.0182 \\
\hline PM Split Study & 0.0154 & 0.0179 \\
\hline Transient (From E-55/59) & 0.0087 & 0.0089 \\
\hline Idle (E-55/59)/Transient Ratio & 1.1954 & 2.0449 \\
\hline
\end{tabular}

For the E-55/59 program NOx/ $\mathrm{CO}_{2}$ ratio for the post $1990 \mathrm{MY}$ vehicles was $75 \%$ higher than the NOx/CO 2 ratio of the MY 1975-1990 MY vehicles, whereas for the PM Split Study this ratio was $26 \%$ higher for the later MY vehicles. However, the PM split Study 
only had three vehicles with MY $1975-1990$. NOx $/ \mathrm{CO}_{2}$ ratio in the Transient mode from the same vehicles of the E-55/59 program showed a different picture. $\mathrm{NOx} / \mathrm{CO}_{2}$ ratio from the Transient mode was lower than the idle $\mathrm{NOx} / \mathrm{CO}_{2}$ ratio and varied little for the later $\mathrm{MY}$ vehicles. High $\mathrm{NOx} / \mathrm{CO}_{2}$ ratio for the later $\mathrm{MY}$ vehicles indicated advanced injection timing on them. Engine manufacturers have been doing this intentionally in order to reduce white smoke and to ensure combustion stability at light loads (during idle). Figure 9 shows the $\mathrm{NOx} / \mathrm{CO}_{2}$ from the idle mode and the Transient mode.

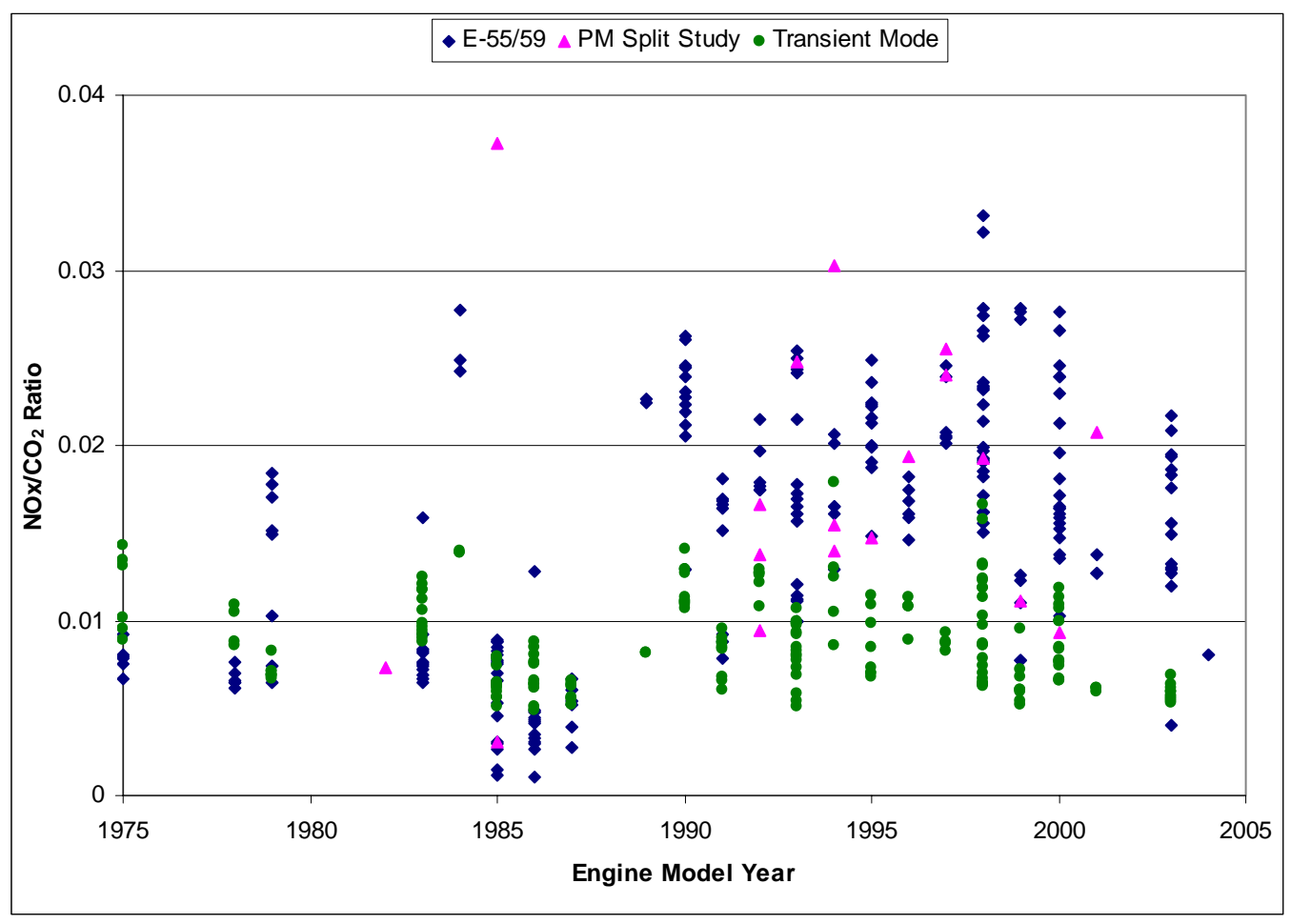

Figure 9: Comparison of idle and transient $\mathrm{NOx} / \mathrm{CO}_{2}$ ratio 


\section{Regulated Emissions}

\section{Carbon Monoxide (CO)}

$\mathrm{CO}$ emissions from heavy-duty diesel vehicles are generally low during normal operation and reduced further during idling. Idle $\mathrm{CO}$ emissions data of sixty-six vehicles have been collected and arranged according to increasing MY in Figure 10. Data showed a decreasing linear trend from 1975 to 2004 although the trend was not that conclusive $\left(\mathrm{R}^{2}=0.08\right)$. These data also showed two divisions from MY 1975-1990 and MY 19912004. Idle CO emissions from the maximum vehicles with MY 1975-1990 averaged approximately $31 \mathrm{~g} / \mathrm{hr}$ whereas the post $1990 \mathrm{MY}$ vehicles averaged $23 \mathrm{~g} / \mathrm{hr}$. In this data set CRC-3, CRC-12 and CRC-4 trucks of the E-55/59 Study had exhibited more than 80 $\mathrm{g} / \mathrm{hr}$ of $\mathrm{CO}$ emissions in some idle test runs. There were equipment malfunction while testing CRC-4 (first run), and it was not considered in the modified data. CRC-3 was repaired and re-tested. Modified data included idle emissions after the repair. CRC-16 and CRC-45 was malfunctioning vehicle and was identified as inspection and maintenance $[I \& M]$ candidates, for which they were excluded from the modified data. CRC-38 was tested with $\mathrm{A} / \mathrm{C}$ and at elevated speed, which were not included in the modified data. Therefore, Eliminating CRC-3 (MY 1985) and CRC-4 (MY 2000) vehicles' idle emissions from the data group provided a more conclusive decreasing trend with increasing engine MY as seen in Figure 11. 


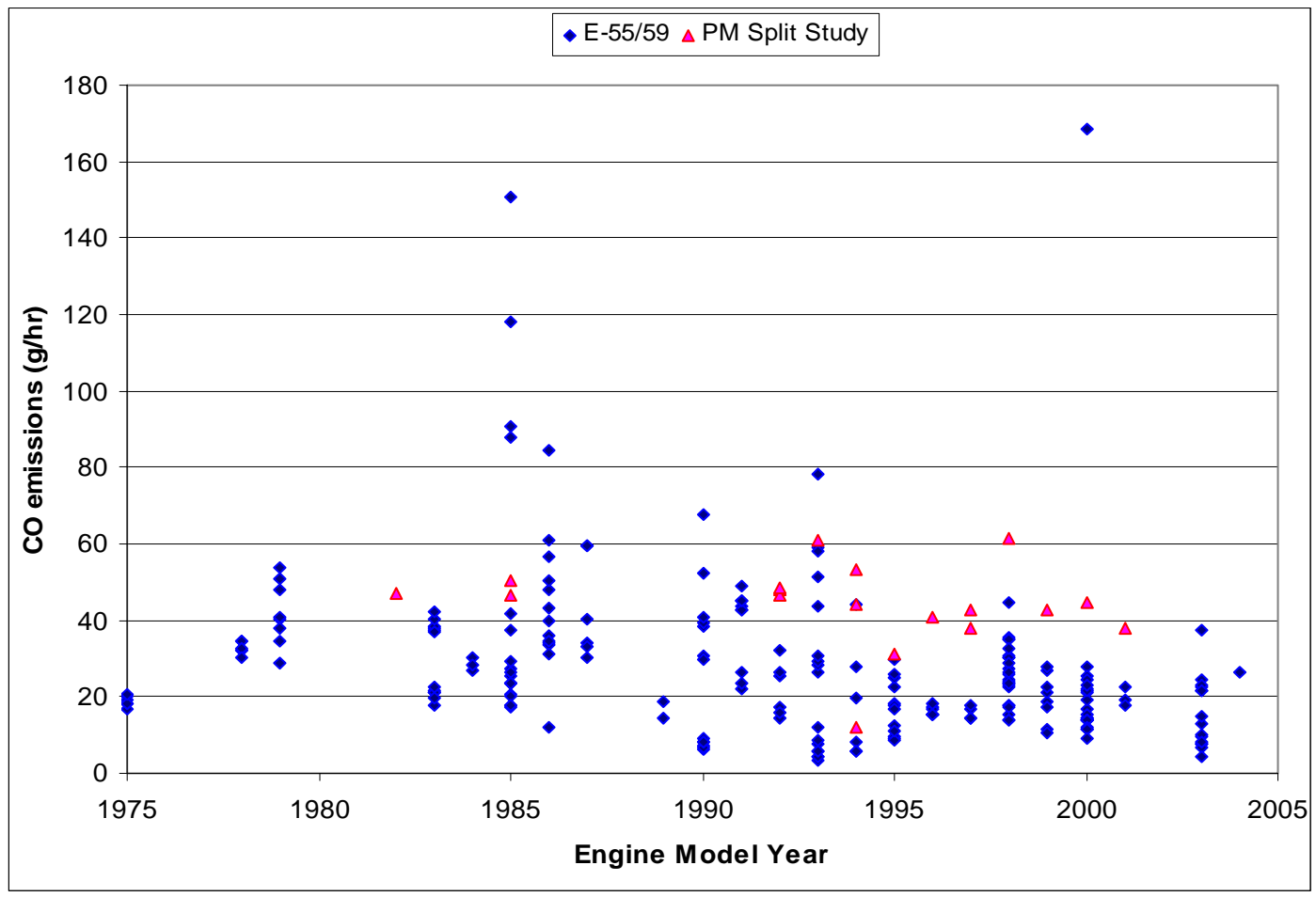

Figure 10: Idle CO emissions

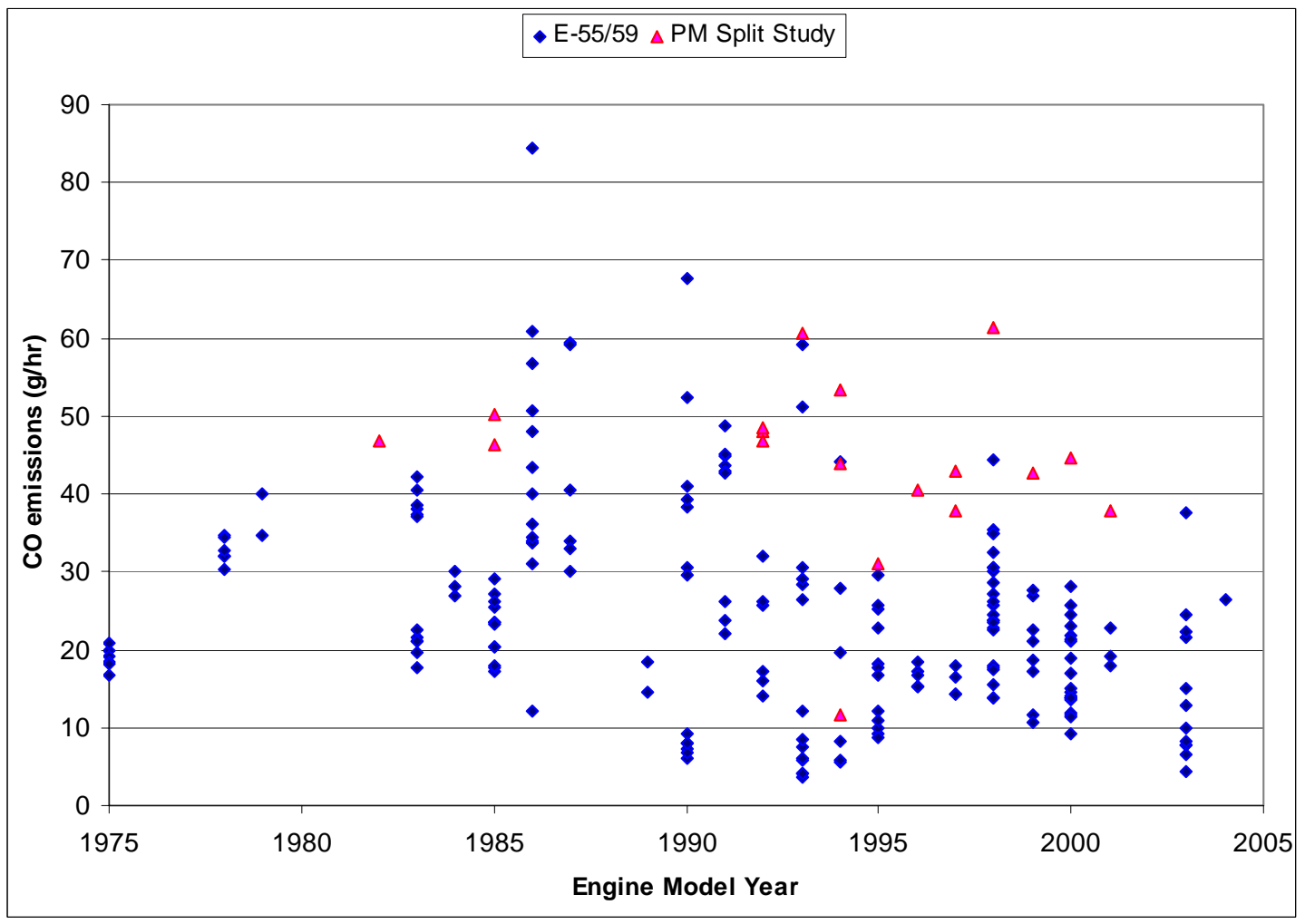

Figure 11: Idle CO emissions, excluding emissions from CRC-16, CRC-38, and CRC-45 trucks. Scale differs from Figure 10 


\section{Hydrocarbons (HC)}

Idle $\mathrm{HC}$ emissions, like idle $\mathrm{CO}$ emissions, from diesel engines are usually very low in comparison to their gasoline counterpart, because of high combustion efficiency. More so, accurate data are difficult to obtain because they may be comparable to ambient background levels. Figure 12 presents the idle HC emissions with increasing engine MY, which showed an apparent downward trend. Idle HC emissions from vehicles with MY 1975-1990 averaged approximately $21 \mathrm{~g} / \mathrm{hr}$ whereas vehicles with post $1990 \mathrm{MY}$ averaged $9 \mathrm{~g} / \mathrm{hr}$. Almost all vehicles from 1975 to $2004 \mathrm{MY}$ had HC emissions less than $50 \mathrm{~g} / \mathrm{hr}$ except CRC-15, CRC-22, and CRC-45 of the E-55/59 Study. HC emissions from CRC-15 truck ranged from $34 \mathrm{~g} / \mathrm{hr}$ to $95 \mathrm{~g} / \mathrm{hr}$ averaging $62 \mathrm{~g} / \mathrm{hr}$, while $\mathrm{HC}$ emissions from CRC-22 ranged from $52 \mathrm{~g} / \mathrm{hr}$ to $65 \mathrm{~g} / \mathrm{hr}$. CRC-45 emitted the highest HC emissions, which ranged from $200 \mathrm{~g} / \mathrm{hr}$ to $315 \mathrm{~g} / \mathrm{hr}$. These vehicles also emitted very high CO and PM emissions on these test-runs. CRC-45 (MY 1993), was an Inspection and Maintenance $[\mathrm{I} \& \mathrm{M}]$ candidate with a number of maintenance problems. On the other hand, in some cases idle HC emissions were too low and could not even be detected accurately. For example, one test-run each from E-55/59 CRC-12, CRC-28, CRC-30 and CRC-40 trucks and PM-19 truck emitted almost zero or below detectable idle HC emissions. Modified HC emissions, which did not include emissions from CRC-3 (before repair), CRC-16, CRC-38, and CRC-45 trucks, showed a downward trend with increasing MY (Figure 13). These findings were contrary to the findings of McCormick et al. [8] who did not observe any trend for idle HC emissions with engine MY. 


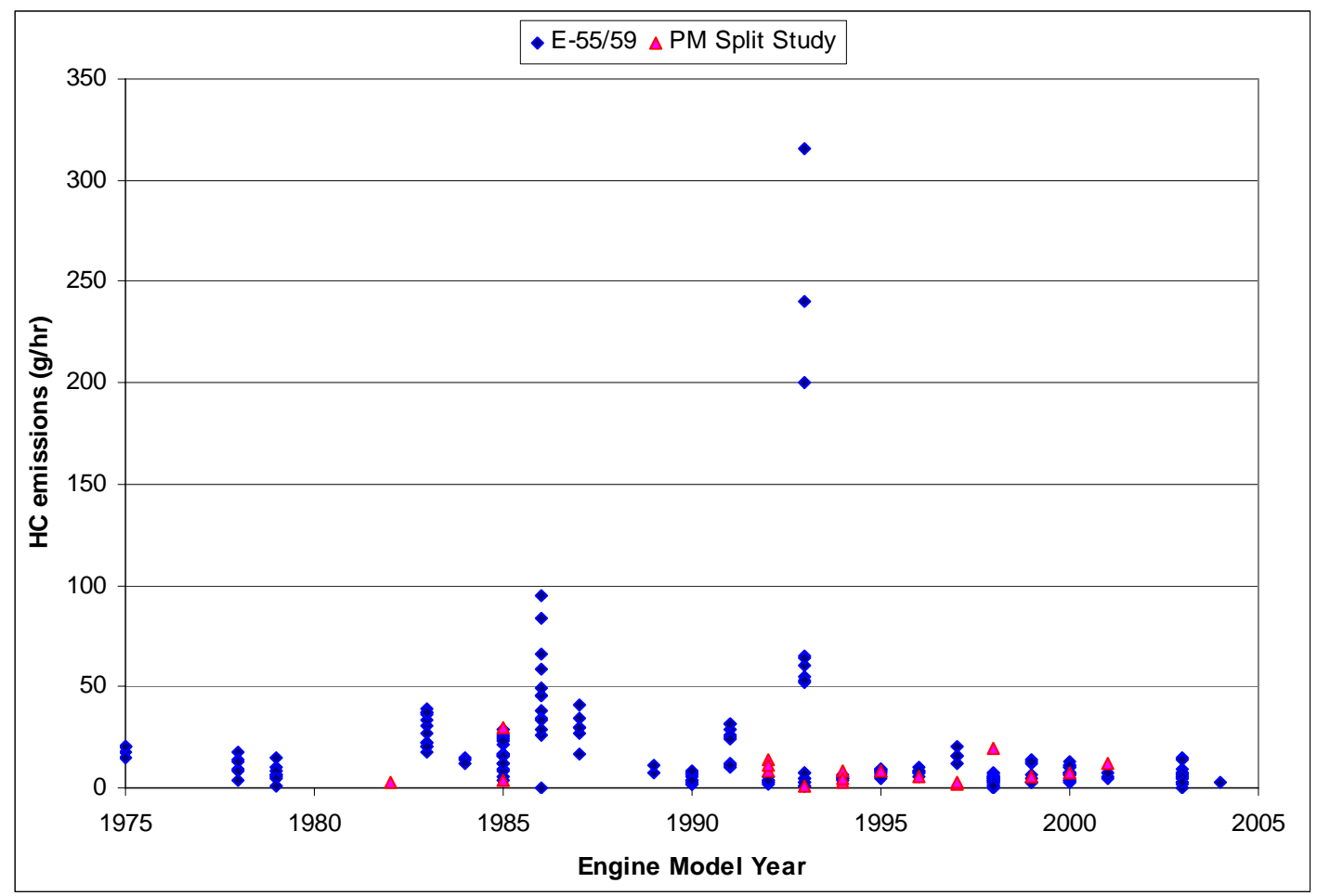

Figure 12: Idle HC emissions

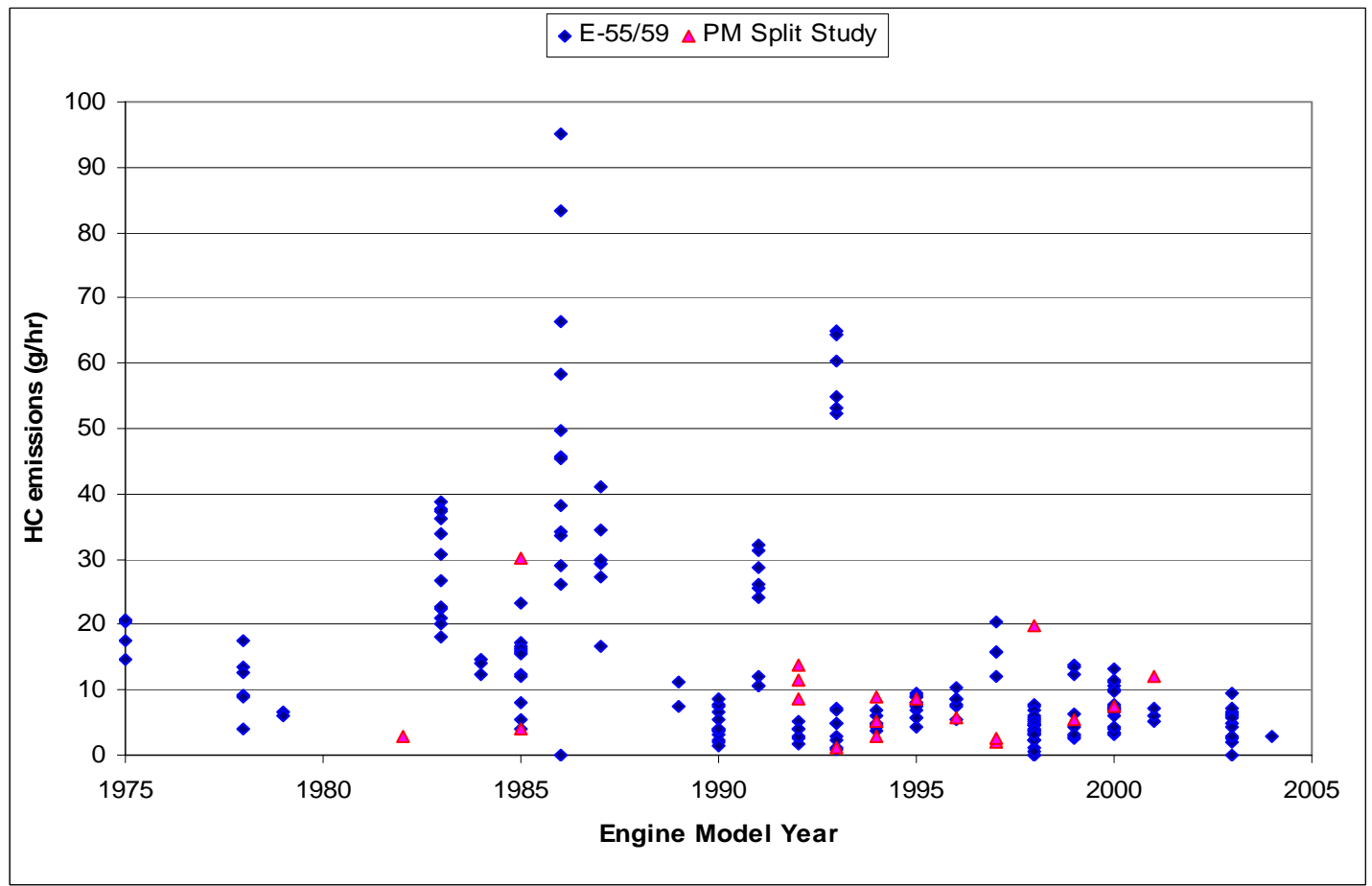

Figure 13: Idle HC emissions excluding emissions from CRC-16, CRC-38, and CRC-45 trucks. Scale differs from Figure 12 


\section{Oxides of Nitrogen (NOx)}

Idle NOx emissions exhibited a total contrast to the idle $\mathrm{CO}$ and $\mathrm{HC}$ emissions. It showed an upward trend with increasing engine MY (Figure 14), which was also demonstrated while observing the $\mathrm{NOx} / \mathrm{CO}_{2}$ ratio. MY 1975-1990 vehicles averaged approximately 46 $\mathrm{g} / \mathrm{hr}$ of idle NOx emissions, whereas vehicles with post 1990 MY emitted approximately $85 \mathrm{~g} / \mathrm{hr}$ of idle NOx emissions. Overall, the idle NOx data varied from approximately 3 $\mathrm{g} / \mathrm{hr}$ to $242 \mathrm{~g} / \mathrm{hr}$. Out of all the vehicles tested CRC-38 truck (MY 2003) of the E-55/59 emitted extremely high NOx emissions, which had been tested with $\mathrm{A} / \mathrm{C}$ and elevated engine speed. Two test-runs on this truck with elevated speed with and without $\mathrm{A} / \mathrm{C}$ had 242 and $207 \mathrm{~g} / \mathrm{hr}$ of idle NOx emissions respectively. Therefore, emissions from these test-runs were excluded in the modified data. The modified NOx emissions also do not include emissions from the CRC-16, CRC-45 trucks. Figure 15 shows modified NOx emissions, which showed an increasing trend with MY. MY 1975-1990 vehicles emitted approximately $48 \mathrm{~g} / \mathrm{hr}$ of NOx while the post 1990 vehicles emitted about $83 \mathrm{~g} / \mathrm{hr}$ of NOx. The increasing trend of NOx emissions with engine MY also confirmed the findings of McCormick et al [8]. 


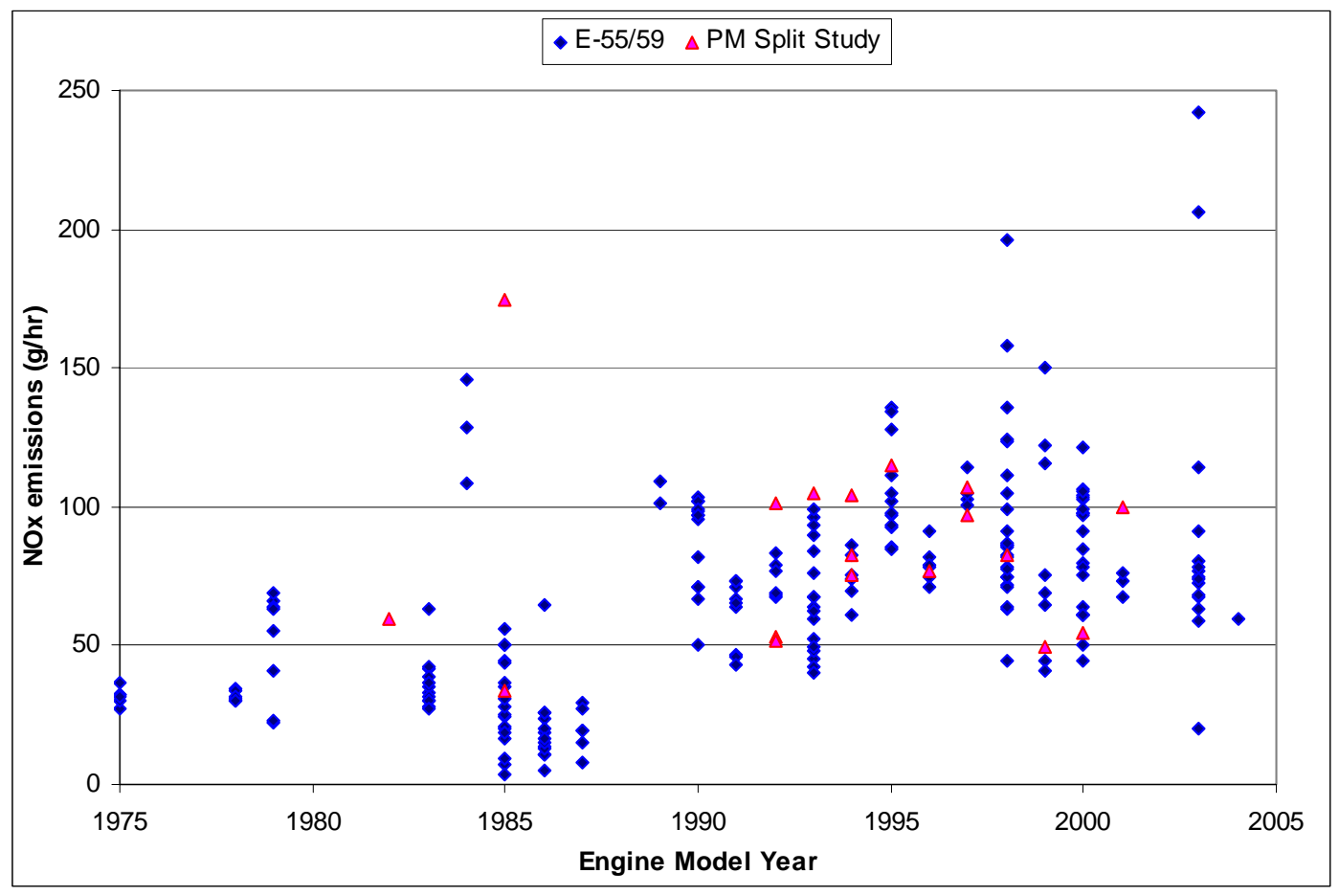

Figure 14: Idle NOx Emissions

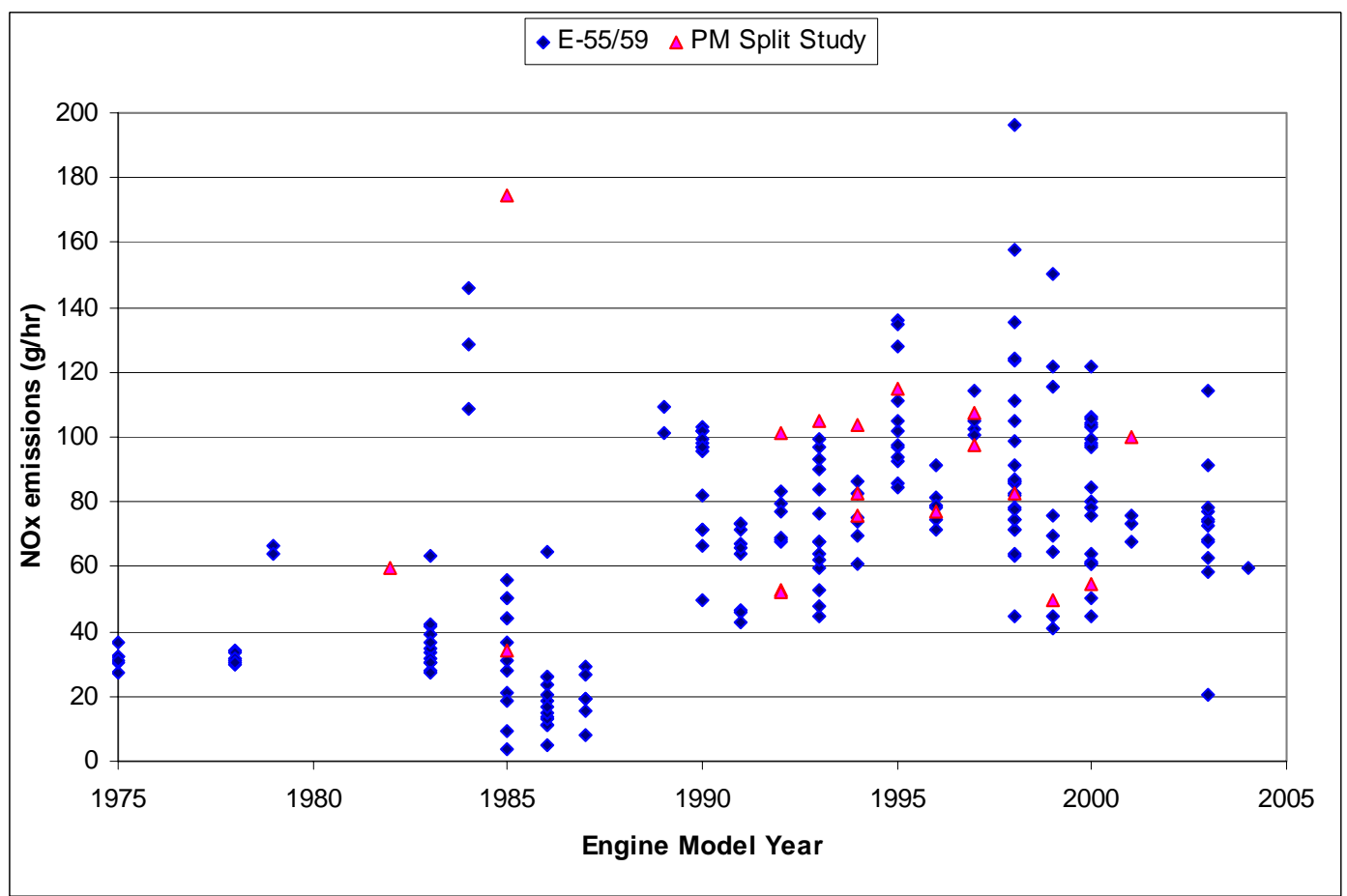

Figure 15: Idle NOx emissions excluding emissions from CRC-16, CRC-38 and CRC-45 trucks. Scale differs from Figure 14 


\section{Particulate Matter (PM)}

Idle particulate emissions are shown in Figure 16. Overall idle PM emissions from these vehicles were very low and in many cases were non-detectable. A downward trend in idle PM emissions with increasing engine MY have been observed for almost all vehicles. CRC-45 vehicle, which emitted exceptionally high idle HC emissions, also emitted exceptionally high PM. Problems associated with that vehicles have already been discussed while discussing $\mathrm{HC}$ emissions. It has also been observed that $\mathrm{CRC}-3$ and CRC-15 vehicles emitted high PM. CRC-3 truck, before repair emitted $10 \mathrm{~g} / \mathrm{hr}$ of PM on average, while after repair it dropped to approximately $5 \mathrm{~g} / \mathrm{hr}$. CRC-15, on the other hand, out of six test-runs emitted more than $10 \mathrm{~g} / \mathrm{hr}$ during three test-runs out of six testruns. No problems were experienced during the testing of these vehicles. Exclusion of PM data from CRC-3, CRC-16, CRC-38 and CRC-45 trucks provided a decreasing trend in PM emissions with increasing engine MY. Figure 17 shows the modified idle PM emissions, which did not include PM emissions from CRC-16, CRC-38, and CRC-45 trucks. MY 1975-1990 vehicles averaged approximately $4.0 \mathrm{~g} / \mathrm{hr}$ of PM whereas MY 1991-2004 averaged approximately $1.4 \mathrm{~g} / \mathrm{hr}$. PM emissions were almost negligible (0.62 $\mathrm{g} / \mathrm{hr}$ ) from vehicles with MY 2000 and beyond. It was interesting to note that some vehicles that were found to emit high NOx were, in contrast, emitted low PM, establishing the 'NOx-PM trade off', although this phenomenon has not been observed over the entire database. 


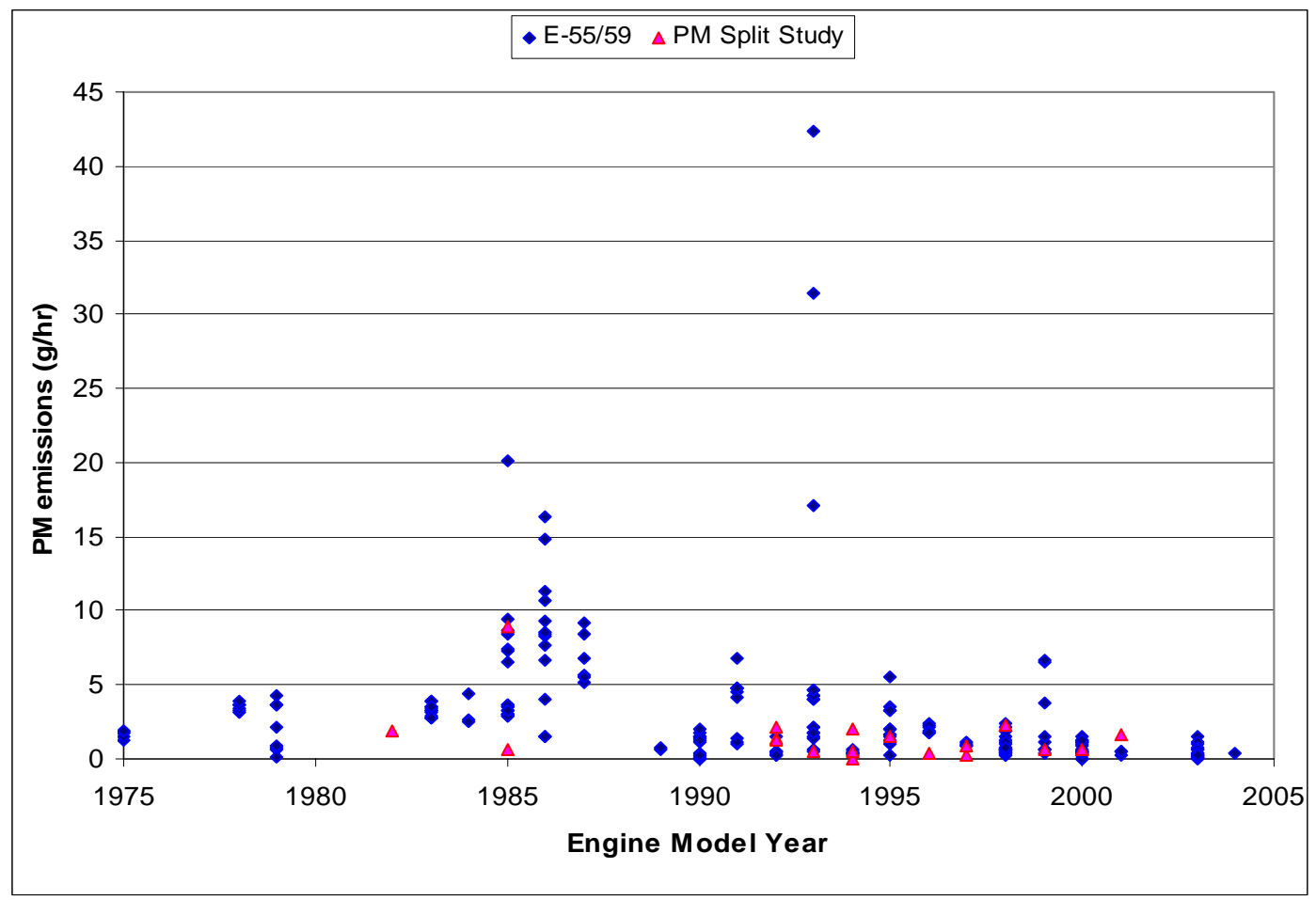

Figure 16: Idle PM emissions

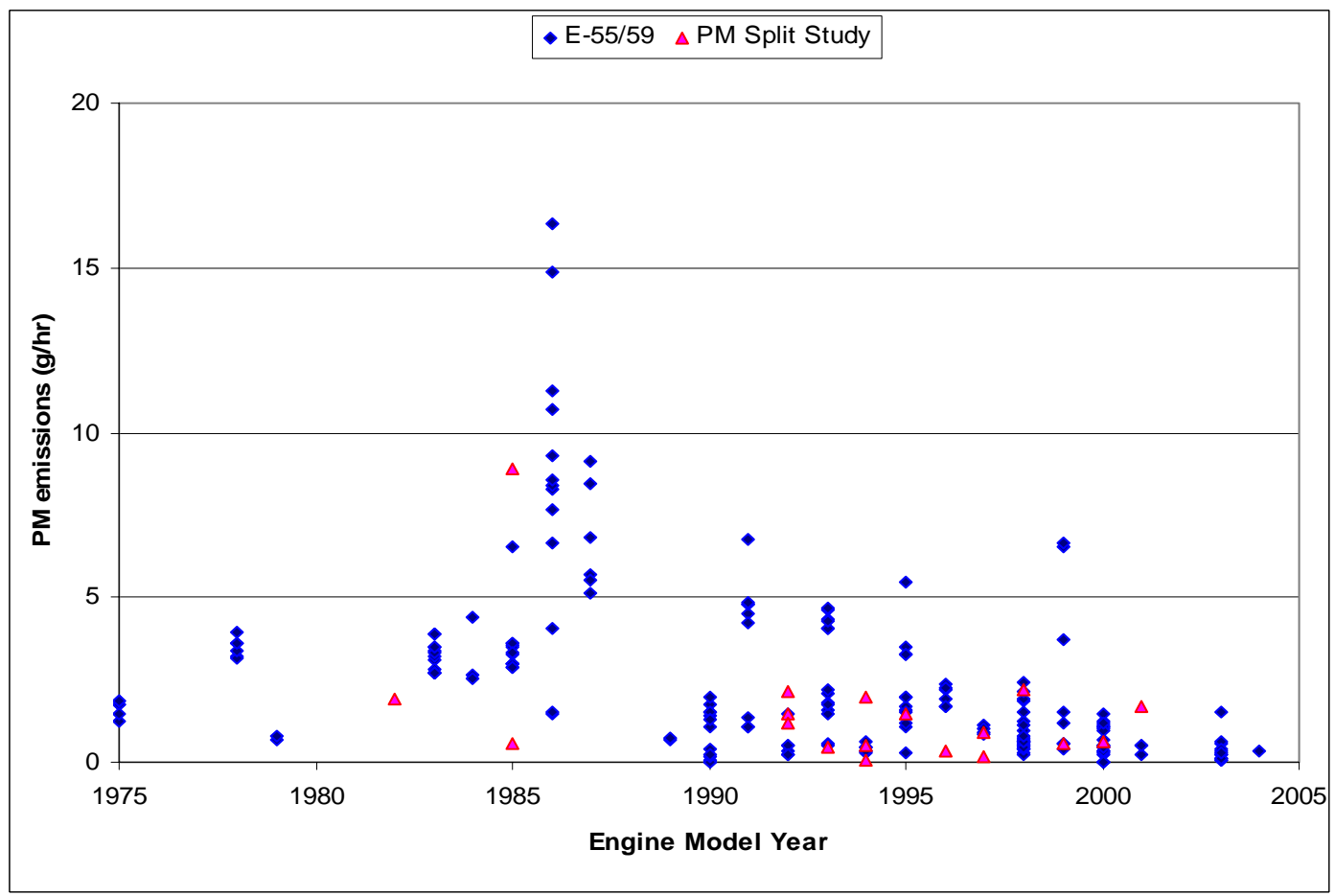

Figure 17: Modified idle PM emissions excluding emissions from CRC-16, CRC-38 and CRC-45 trucks. Scale differs from Figure 16 


\section{$\mathrm{CO}_{2}$ Emissions}

Carbon dioxide $\left(\mathrm{CO}_{2}\right)$ is a major green house gas (GHG) produced during complete or incomplete combustion. The USEPA at present does not regulate $\mathrm{CO}_{2}$ emissions. With increased focus on climate change and global warming it is expected that $\mathrm{CO}_{2}$ emissions will be regulated in future [26]. Figure 18 shows that $\mathrm{CO}_{2}$ emissions maintained a uniform trend for almost all vehicles considered in this study except CRC-4 and CRC-38 trucks of the E-55/59 Study, and PM-31 and PM-16 vehicles of the PM Split Study, which emitted more than $8,000 \mathrm{~g} / \mathrm{hr}$ of $\mathrm{CO}_{2}$ emissions. It has already been mentioned that CRC-38 was tested at high idle engine speed and with air conditioning, which in turn was responsible for high $\mathrm{CO}_{2}$ emissions. CRC-4 truck emitted approximately $9000 \mathrm{~g} / \mathrm{hr}$ of $\mathrm{CO}_{2}$ in the first test-run, in which it had equipment malfunction problem, although the average $\mathrm{CO}_{2}$ from this truck was approximately $5500 \mathrm{~g} / \mathrm{hr}$. PM-31, a 2-stroke diesel bus emitted about $11,000 \mathrm{~g} / \mathrm{hr}$ of $\mathrm{CO}_{2}$ emissions, which is natural as 2-stroke vehicles consumed more fuel because of inefficient combustion. No problems were reported for other test-runs having more than $8,000 \mathrm{~g} / \mathrm{hr}$ of $\mathrm{CO}_{2}$ emissions. Modified $\mathrm{CO}_{2}$ emissions are presented in Figure 19, which did not take into account the high $\mathrm{CO}_{2}$ emissions from CRC-16, CRC-38 and CRC-45 trucks. The modified data demonstrated a more static trend. No distinct division could be drawn for vehicle groups with MY 1975-1990 and the post $1990 \mathrm{MY}$. However, the average $\mathrm{CO}_{2}$ emissions from these two groups were approximately $4614 \mathrm{~g} / \mathrm{hr}$ and $4504 \mathrm{~g} / \mathrm{hr}$ respectively. 


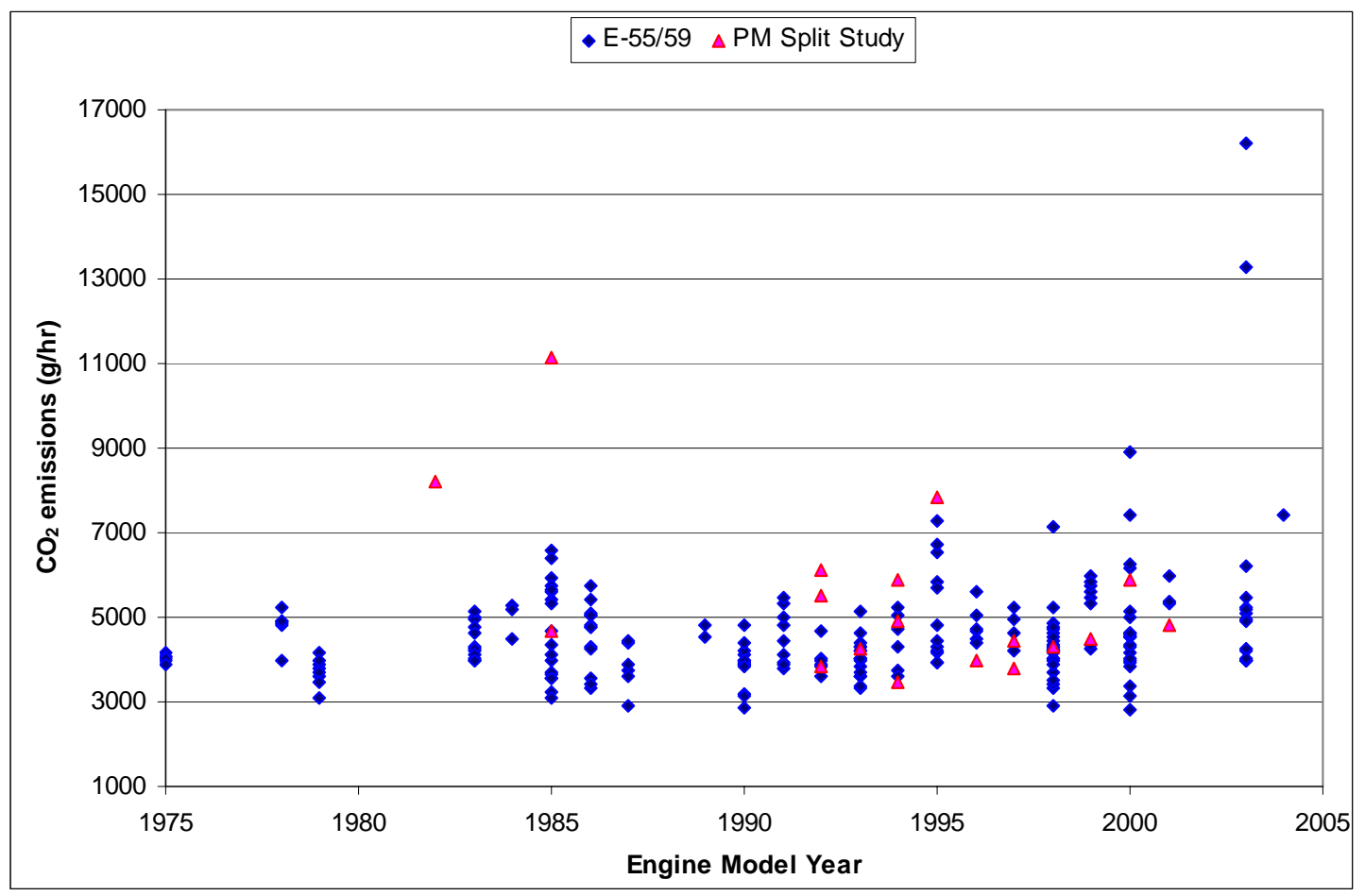

Figure 18: Idle $\mathrm{CO}_{2}$ emissions

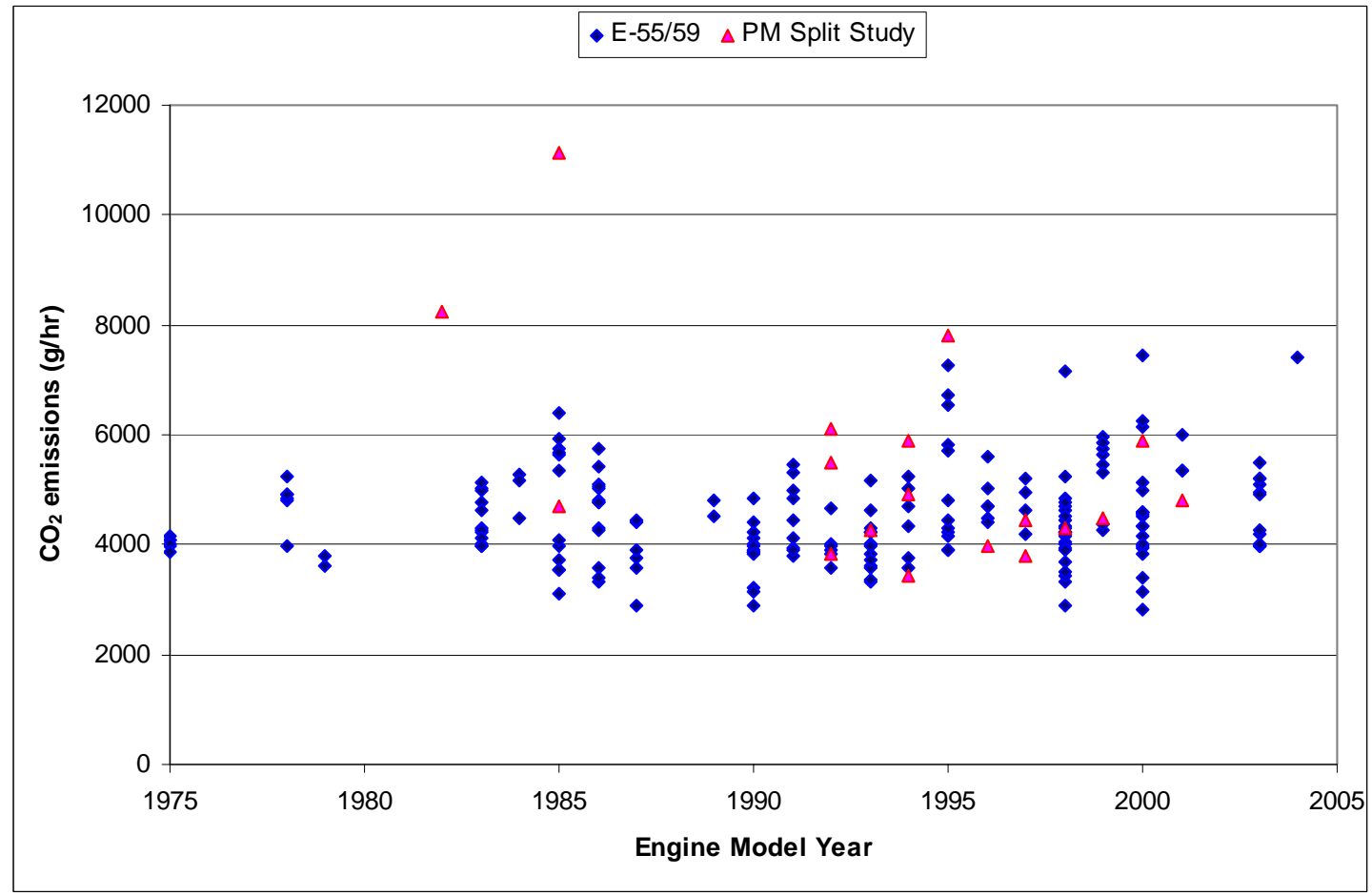

Figure 19: Idle $\mathrm{CO}_{2}$ emissions excluding emissions from CRC-16, CRC-38 and CRC-45 trucks. Scale differs from Figure 18 


\section{Idle Fuel Consumption}

Like regulated emission, no conclusive figure has been available for idle fuel consumption in literature. This value ranged from 0.3 gallons per hour (gal/hr) to $1.0 \mathrm{gal}$ per hour in the literature. In order to present a comprehensive data base, idle fuel consumption has been evaluated from all trucks from the E-55/59 Study and the PM Split Study, which are presented in Figure 20. Overall these data maintained a constant trend, which was expected as fuel consumption has been inferred from $\mathrm{CO}_{2}$ emissions by carbon balance. Fuel consumption from these vehicles varied from $0.31 \mathrm{gal} / \mathrm{hr}$ to $1.62 \mathrm{gal} / \mathrm{hr}$. On average, vehicles with MY 1975-1990 and post 1990 MY consumed fuel at an hourly rate of 0.46 and 0.47 gallons respectively. A number of vehicles were found to consume more than $1.0 \mathrm{gal} / \mathrm{hr}$ in both the E-55/59 and the PM Split Study. Out of these vehicles, fuel consumption from the CRC-16, CRC-38 and CRC-45 truck has been excluded because of the reasons mentioned in previous sections. The modified fuel consumption is shown in Figure 21. It is worth mentioning that a comprehensive database on idle fuel consumption from heavy-duty diesel buses and trucks is not available. Wider variations have also been observed in idle fuel consumption from the available literature. 


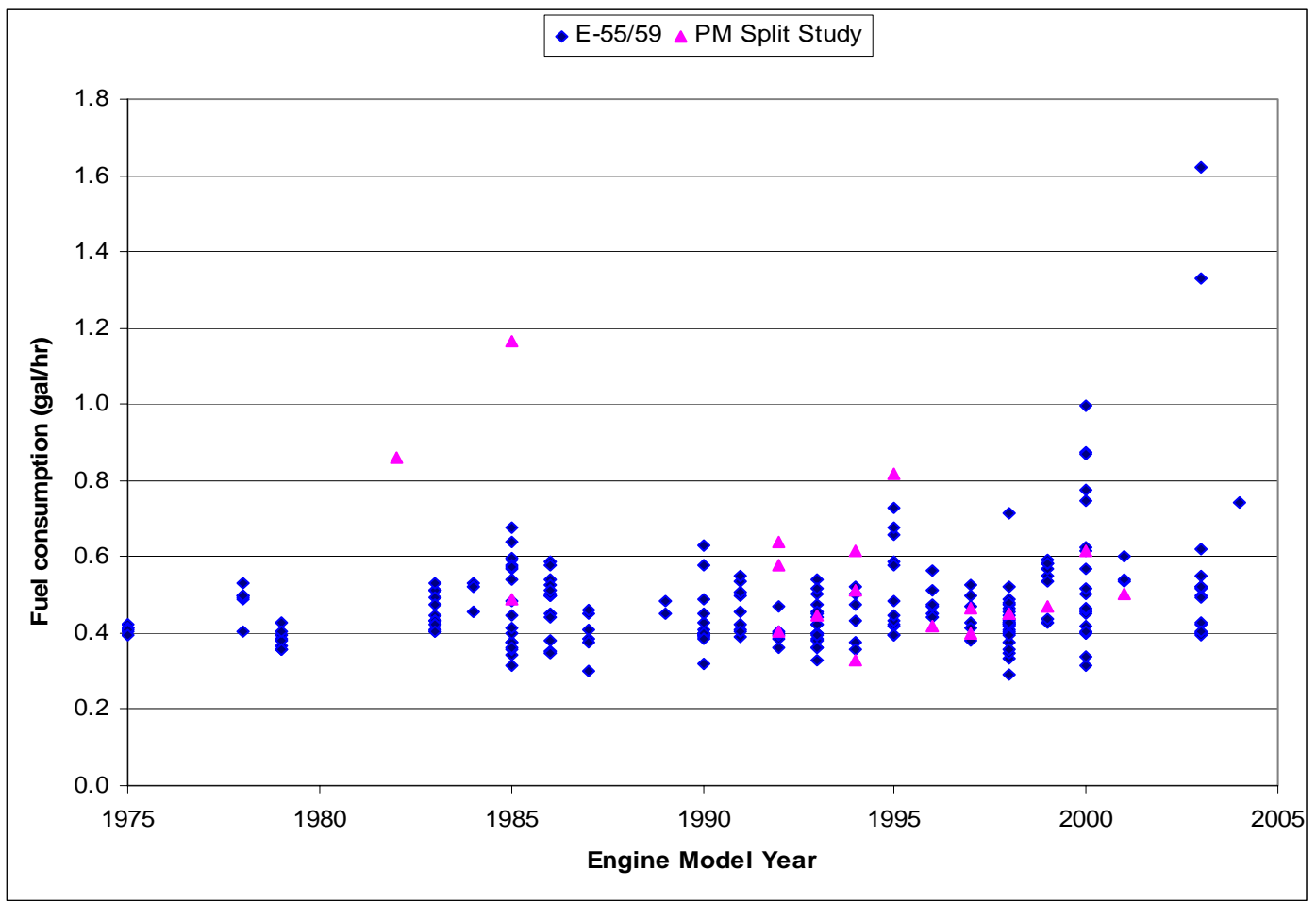

Figure 20: Idle fuel consumption in gallons per hour

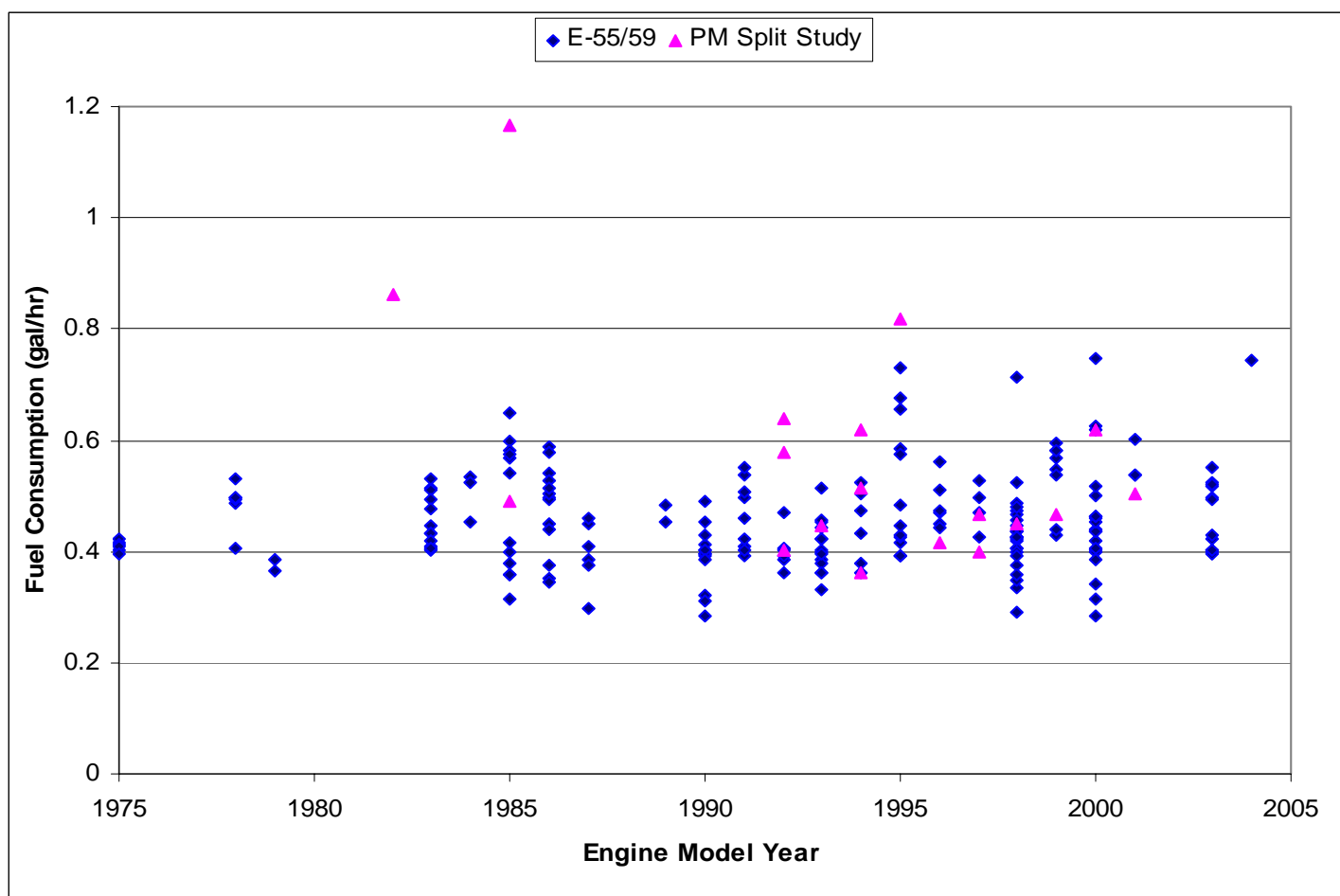

Figure 21: Modified idle fuel consumption excluding CRC-16, CRC-38 and CRC-45 trucks. Scale differs from Figure 20 


\section{Effect of Air Conditioning and Idle Speed on Idle Emissions}

To observe the effects of engine speed and A/C on idle emissions, CRC-38 (MY 2003) truck was tested on 4 different modes. They are (i) idle at $600 \mathrm{rpm}$ without A/C, (ii) idle at $600 \mathrm{rpm}$ with $\mathrm{A} / \mathrm{C}$, (iii) idle at $1100 \mathrm{rpm}$ without $\mathrm{A} / \mathrm{C}$, and (iv) idle at $1100 \mathrm{rpm}$ with A/C. Effects of these varying conditions are plotted in Figure 22. It has been observed that $\mathrm{CO}_{2}, \mathrm{NOx}, \mathrm{PM}$, and fuel consumption increased by $25 \%, 30 \%, 20 \%$, and $27 \%$ respectively with the addition of $\mathrm{A} / \mathrm{C}$ at $600 \mathrm{rpm}$ engine speed. Whereas, elevating the idle engine speed from $600 \mathrm{rpm}$ to $1100 \mathrm{rpm}$ caused an increase in $\mathrm{CO}_{2}, \mathrm{NOx}, \mathrm{PM}$, and fuel consumption by $165 \%, 225 \%, 76 \%$, and $170 \%$ respectively. Pekula et al. [11] also observed the effect of elevated speed on idle $\mathrm{NOx}$ and $\mathrm{CO}_{2}$ emissions and found that $\mathrm{NOx}$ increased by about $86 \%$ and $\mathrm{CO}_{2}$ increased by about $132 \%$ when the engine speed was elevated from $600 \mathrm{rpm}$ to $1200 \mathrm{rpm}$. Use of $\mathrm{A} / \mathrm{C}$ at elevated speed (1100 rpm) increased $\mathrm{CO}_{2}$, NOx, PM, and fuel consumption by $22 \%, 17 \%, 16 \%$, and $22 \%$ respectively. It also affected the fuel economy by almost $70 \%$. Elevating the engine speed from $600 \mathrm{rpm}$ to $1100 \mathrm{rpm}$ and keeping the $\mathrm{A} / \mathrm{C}$ on increased $\mathrm{CO}_{2}, \mathrm{NOx}$, and $\mathrm{PM}$, by $225 \%, 284 \%$ and $100 \%$ respectively. Brodrick et al. [9] also observed the effect of engine speed with $\mathrm{A} / \mathrm{C}$ on idle emissions and found that elevating the engine speed from 600 rpm to $1050 \mathrm{rpm}$ (with $\mathrm{A} / \mathrm{C}$ on in both cases) resulted corresponding increase in idle $\mathrm{CO}$, $\mathrm{NOx}$, and $\mathrm{CO}_{2}$ emissions by approximately $460 \%, 53 \%$ and $90 \%$ respectively. Point to note that air conditioning load depends on temperature, humidity, and heat load and therefore, may not be repeatable. Clark et al. [24] also examined the effect of A/C and accessory loadings on idle emissions on a Mack tractor and found that switching on all the lights and $\mathrm{A} / \mathrm{C}$ affected continuous $\mathrm{CO}_{2}$ and $\mathrm{NOx}$ emissions as shown in Figure 23 and Figure 24. $\mathrm{CO}_{2}$ and $\mathrm{NOx}$ on average increased by about $60 \%$ and $45 \%$ respectively when the lights and A/C switched on. Variation observed on the Mack Tractor was more than the variation observed in CRC-38 truck because CRC-38 truck has been experimented with only the $\mathrm{A} / \mathrm{C}$ at the same engine speed. 


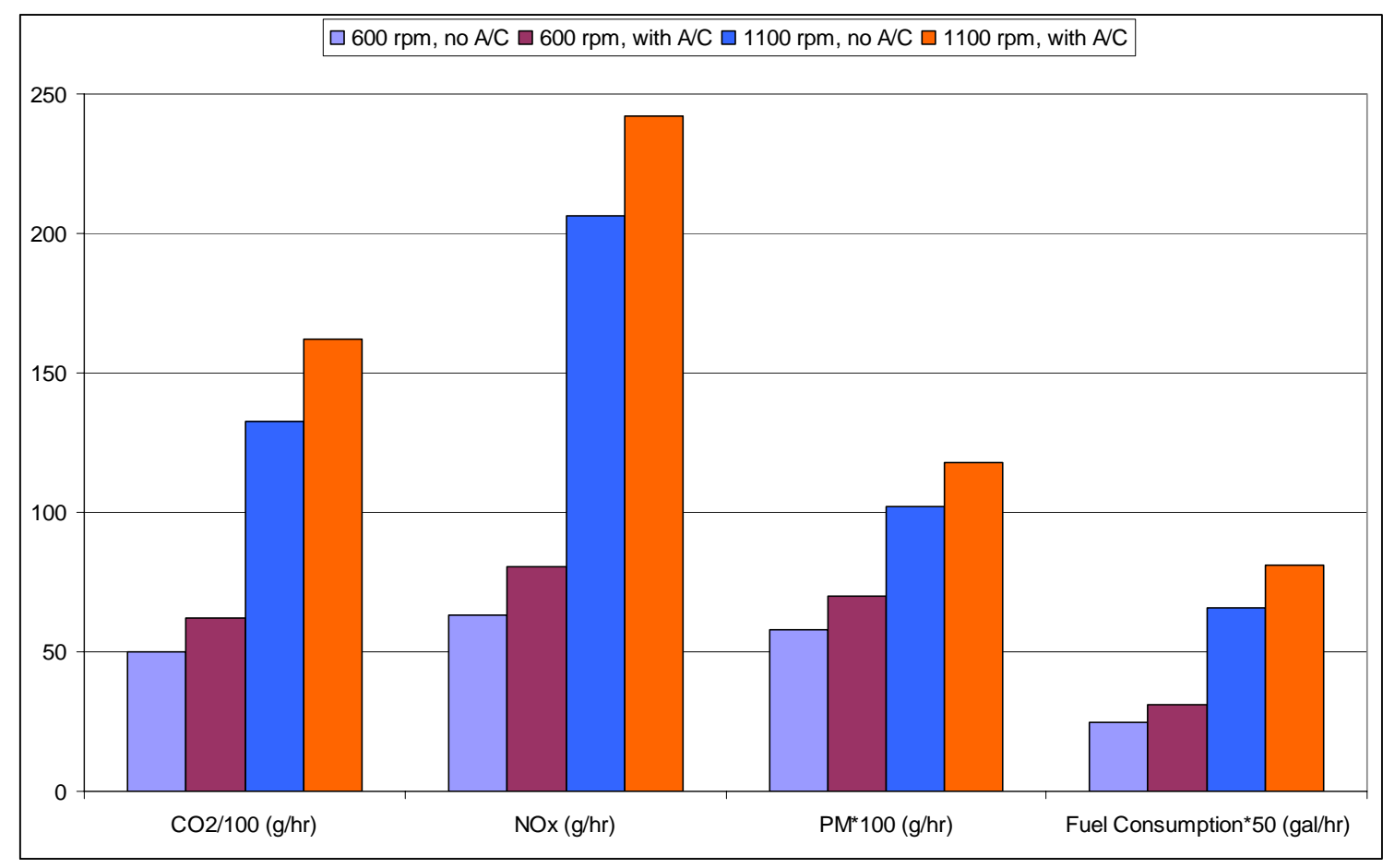

Figure 22: Effects of engine speed and air conditioning on idle emissions and fuel consumption

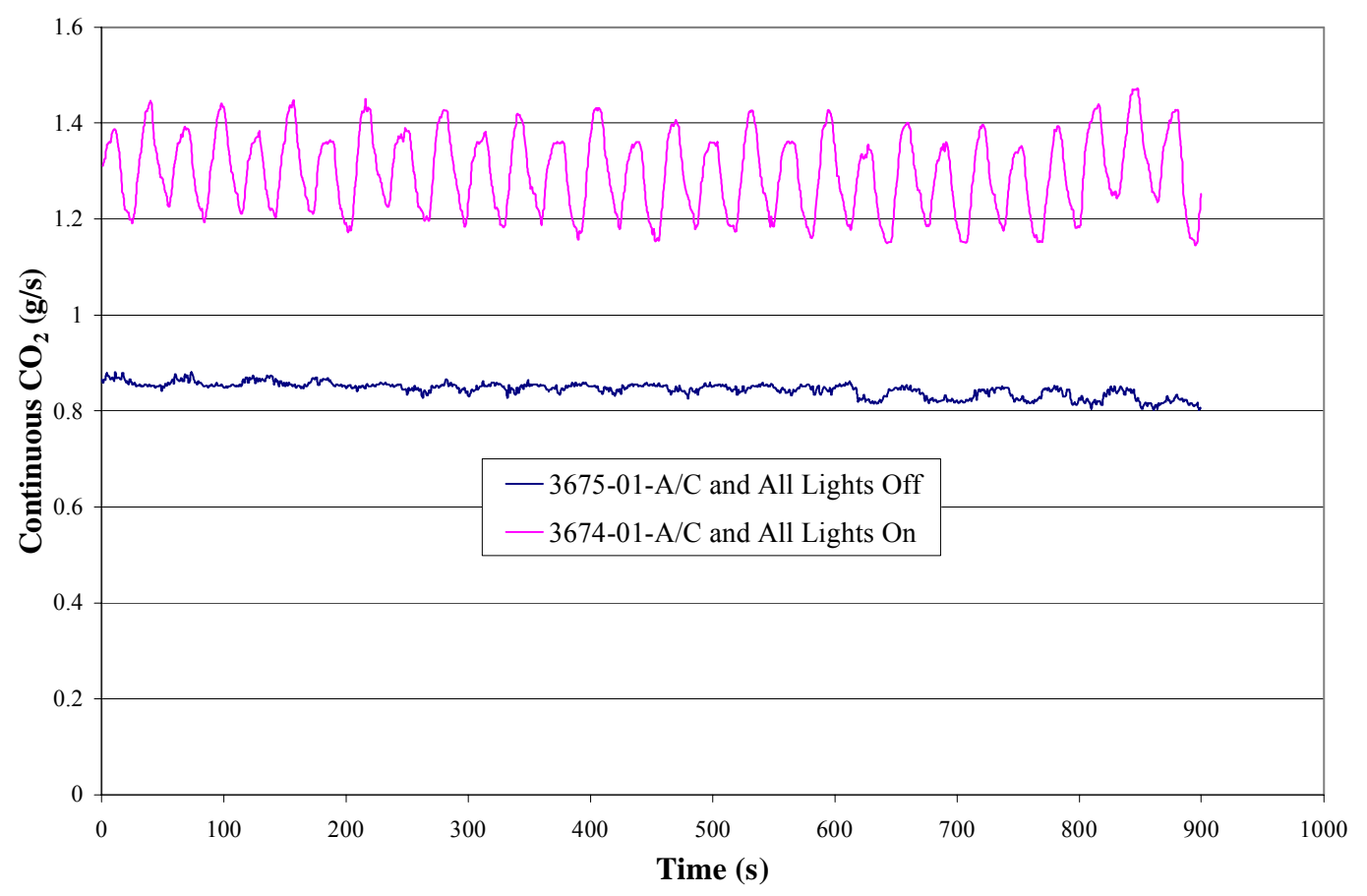

Figure 23: $\mathrm{CO}_{2}$ concentration over the idle mode with different engine accessories operating, Mack tractor 


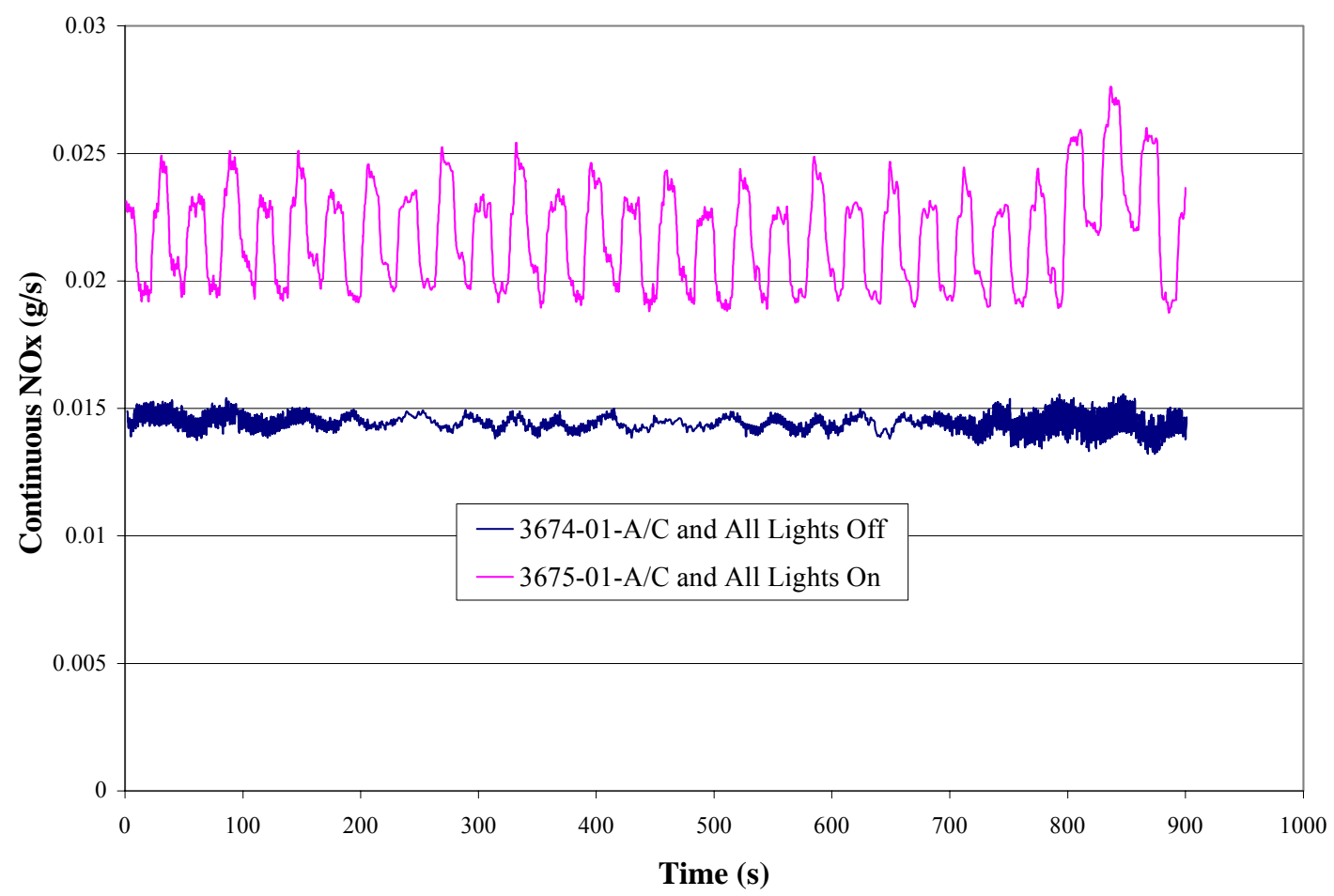

Figure 24: $\mathrm{NO}_{\mathrm{X}}$ concentration over the idle mode with different engine accessories operating, Mack tractor

\section{Idle Emissions from Transit Buses}

Idle emissions from three transit buses have been presented separately because of their continuous exposure to the people of all ages who wait at the bus depots or various bus stops. Two buses were tested during the PM Split Study and the third bus was recently tested during the Transit Vehicle Exhaust Emissions Evaluation project, which has been sponsored by the U.S. Department of Transportation (DOT), Federal Transit Administration (FTA) [27]. Bus 1 referred to as PM-31, which had a 1982 DDC 6V92/8067-3421 2-stroke diesel engine with mechanical injection system while Bus 2 referred to as PM-32, which had a 1992 DDC 6V92/8067-3 K21 2-stroke diesel engine with electronic fuel injection. Bus 3 was a 2000 MY DDC Series 50 bus with 4-stroke diesel engine equipped with electronic fuel injection. Emissions data from these buses are presented in Figure 25. All emissions except NOx from the two 2-stroke diesel buses were higher than the MY 2000 bus. PM emissions from the Bus 1 was about $600 \%$ higher than the PM emissions from Bus 3 while PM emissions from Bus 2 was 400\% more than 
PM emissions from Bus 3. Bus 1 also emitted high $\mathrm{CO}_{2}$, because the bus employed mechanical injection. However, 2-stroke diesel buses produced less NOx than Bus3 establishing the NOx-PM tradeoff.

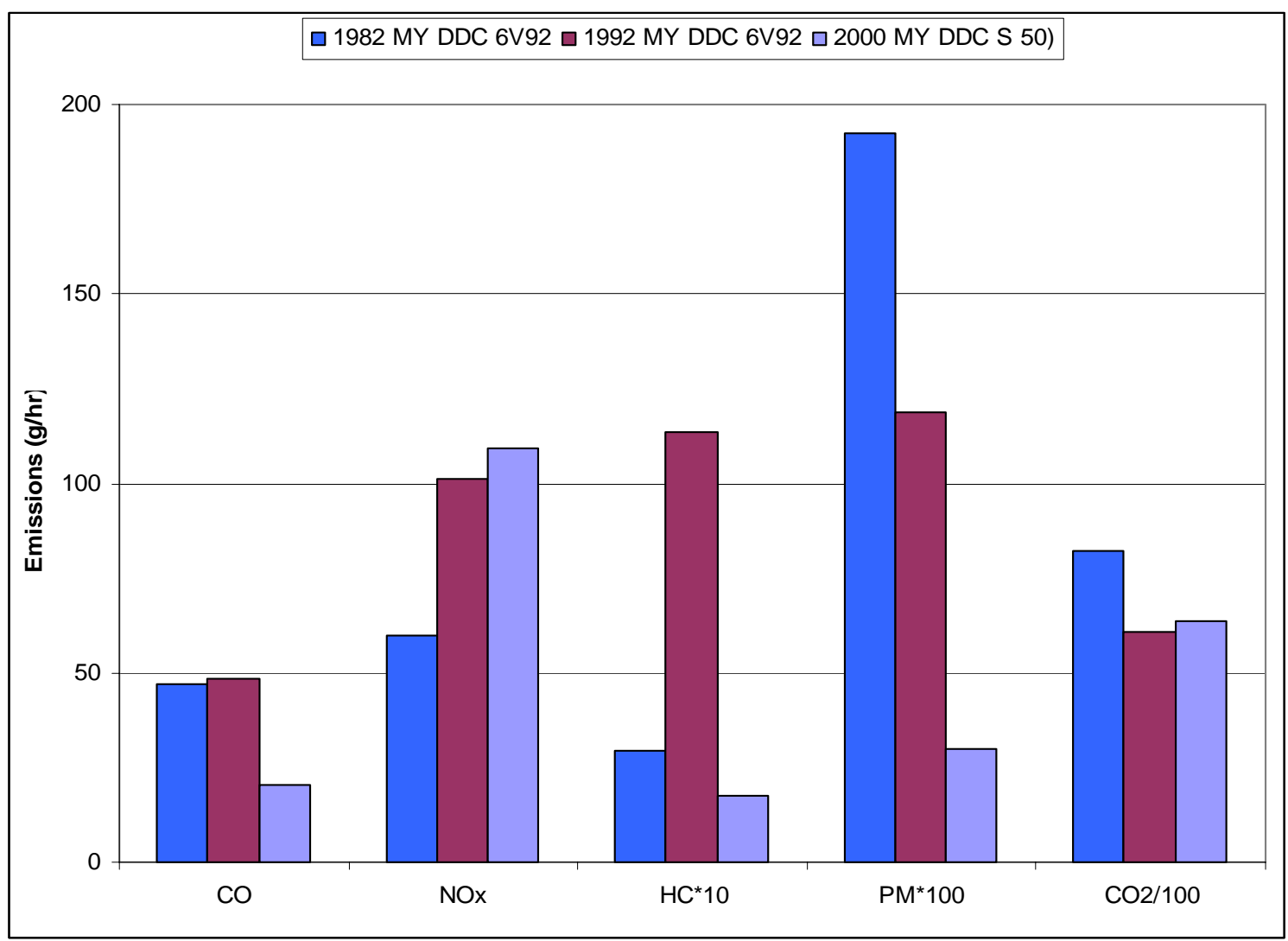

Figure 25: Idle emissions from three transit buses

\section{COMPARISON OF IDLE EMISSIONS FROM THE TRANSIENT MODE AND IDLE CYCLE}

\section{Evaluating Idle Emissions from Transient Mode of the HHDDT Schedule}

In addition to the direct measurement of emissions on idle cycles, idle emissions can also be obtained from the continuous emissions data of any test schedule, because every test schedule has a certain percentage of idle. It is both time saving and cost effective. However, the reliability of these data could be achieved by comparing these data with idle emissions data gathered from the drive cycles. Almost all heavy-duty trucks during 
the E-55/59 program, in addition to idle cycles, were tested on Transient and Creep mode of the HHDDT Schedule [28]. The HHDDT schedule consisted of four original modes, namely; Idle, Creep, Transient, and Cruise. In this evaluation, continuous emissions data of the Transient mode has been considered. Figure 26 shows the Transient mode of the HHDDT Schedule. Idle emissions of $\mathrm{CO}, \mathrm{NOx}, \mathrm{HC}$, and $\mathrm{CO}_{2}$ from the Transient mode have been obtained from the three idle segments as seen in the figure. Continuous emissions in grams per second has been averaged over the idle duration and presented in $\mathrm{g} / \mathrm{hr}$. This could be accomplished in two different ways.

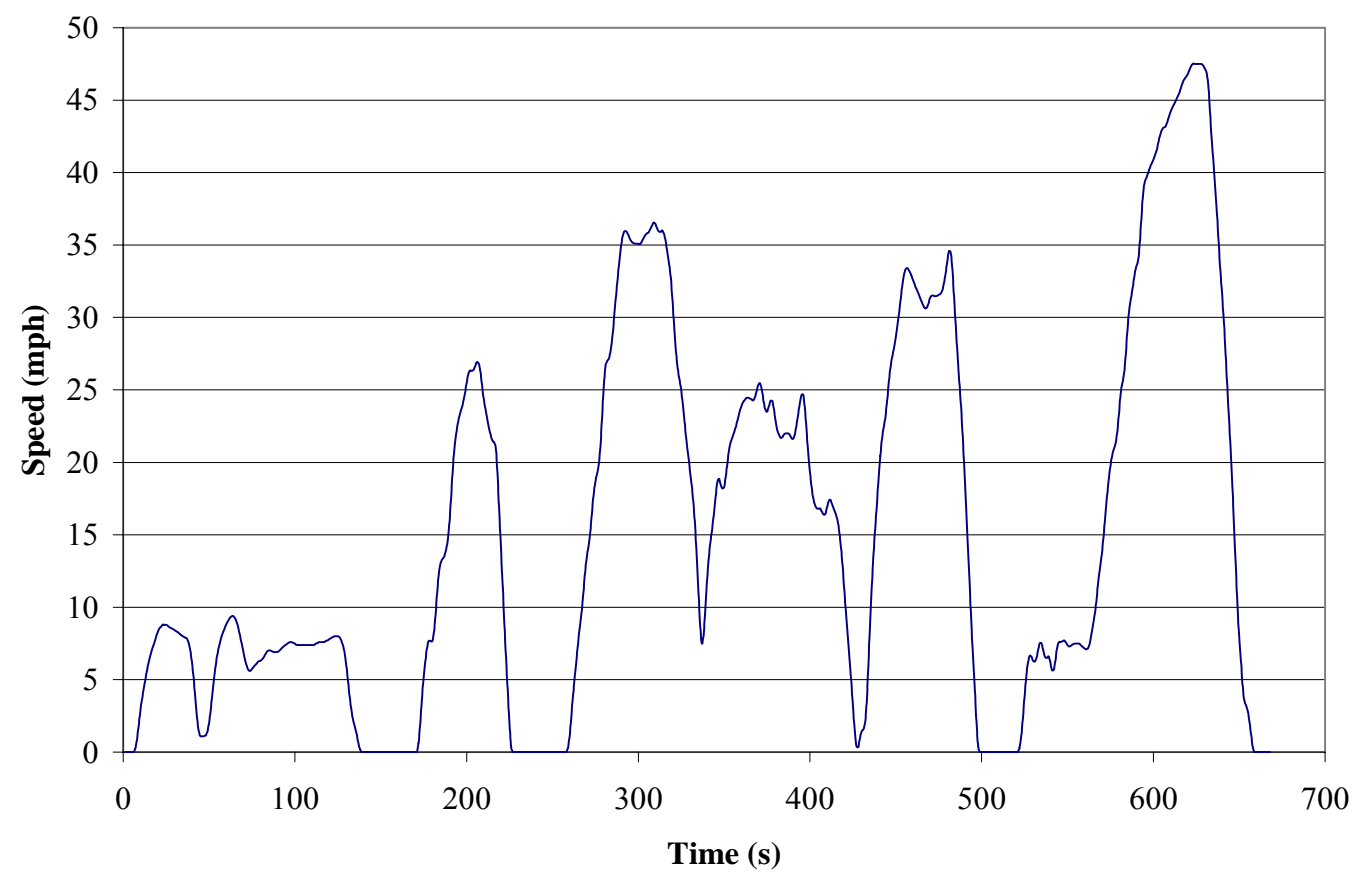

Figure 26: Transient mode of the HHDDT Schedule

For example, continuous NOx emissions trace from CRC-2 truck with respect to hub speed and power are presented in Figure 27 and Figure 28. In the simplest form, idle NOx can be obtained from the following figures considering the equations $\mathrm{y}=3 \mathrm{E}$ $06 x^{2}+0.0006 x+0.072$ and $y=4 E-07 x^{2}+0.0004 x+0.0312$ and taking $x=0$, because the hub power and speed during idle should theoretically be zero. Idle emissions obtained with this method largely depend on the $\mathrm{R}^{2}$ value. Therefore, these values could have wide variations with the values obtained from idle cycle. For example, idle NOx emissions 
obtained from Figure 27 and Figure 28 are $262.44 \mathrm{~g} / \mathrm{hr}$ and $112.32 \mathrm{~g} / \mathrm{hr}$ respectively, while this value from the idle cycle was $111.2 \mathrm{~g} / \mathrm{hr}$. Moreover, neither the hub power nor the hub speed remained absolutely zero during idle as showed in Figure 29 and Figure 30. These figures represent the continuous idle NOx emissions for the same truck with respect to hub power and hub speed respectively, from which it has been observed that hub power varied from $-0.002 \mathrm{hp}$ to $0.035 \mathrm{hp}$ and the hub speed varied from $-2.0 \mathrm{rpm}$ to $3.2 \mathrm{rpm}$. Therefore, in order to accurately obtain the idle values from the continuous emissions, continuous $\mathrm{CO}, \mathrm{HC}, \mathrm{NOx}$, and $\mathrm{CO}_{2}$ emissions with hub speed less or equal to $3.0 \mathrm{rpm}(<=3.0)$ has been regarded as idle emissions and presented in Table 5. The table also compiles the idle values from the idle cycle for respective trucks on the corresponding test run.

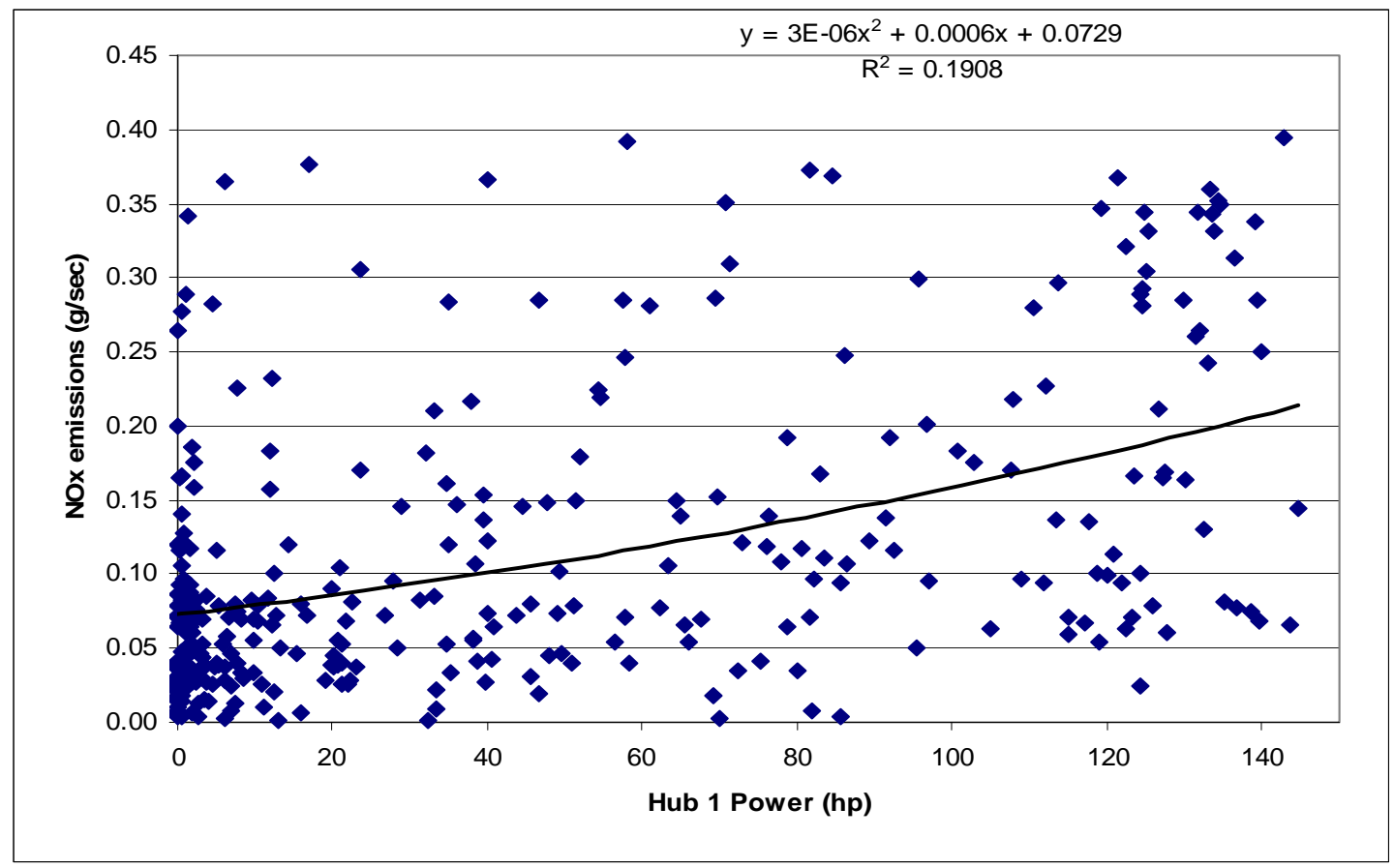

Figure 27: Continuous NOx emissions with respect to hub power (hp) for the E-55/59 CRC-2 truck 


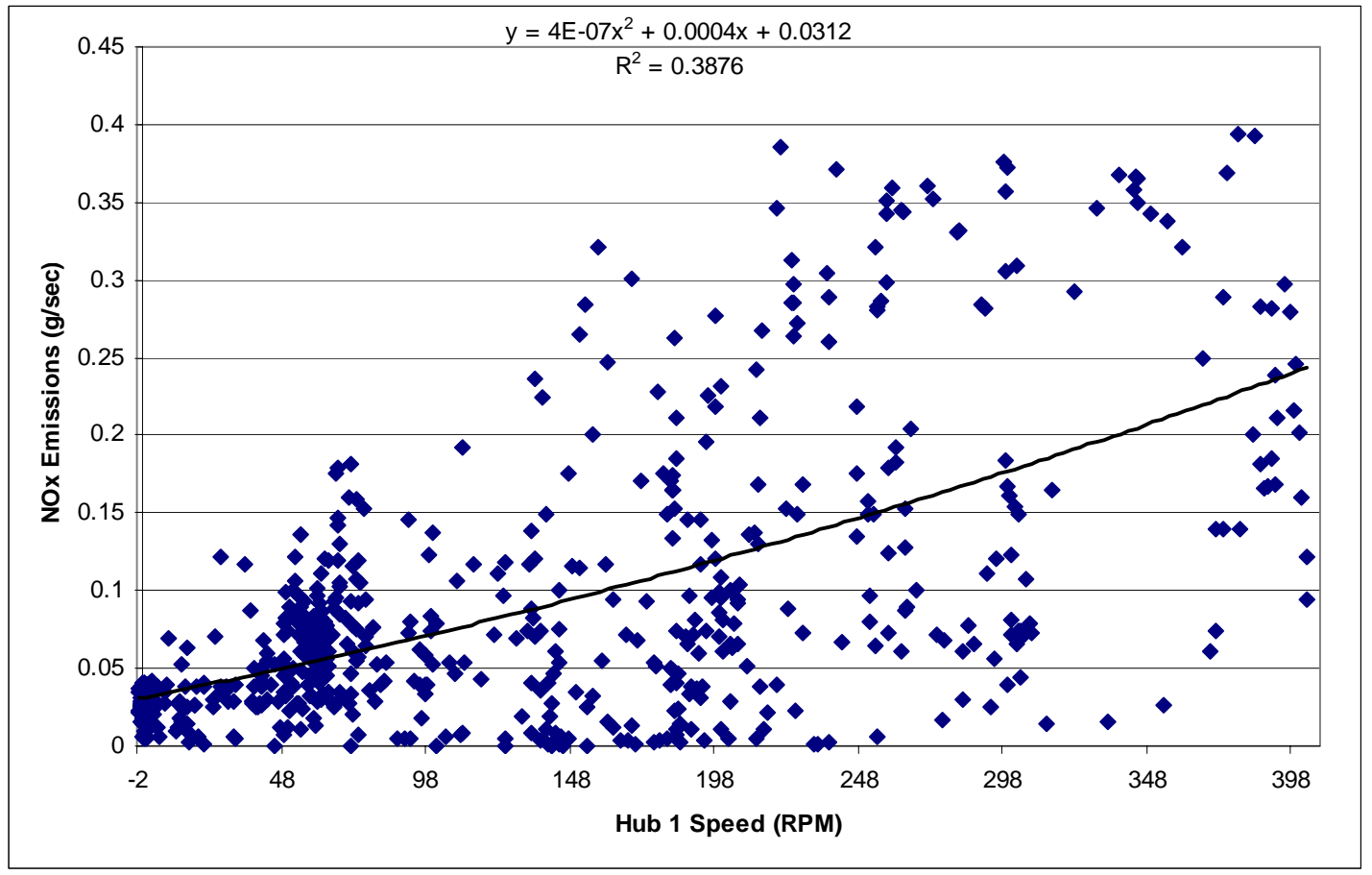

Figure 28: Continuous NOx emissions with respect to hub speed (rpm) for the E-55/59 CRC-2 truck

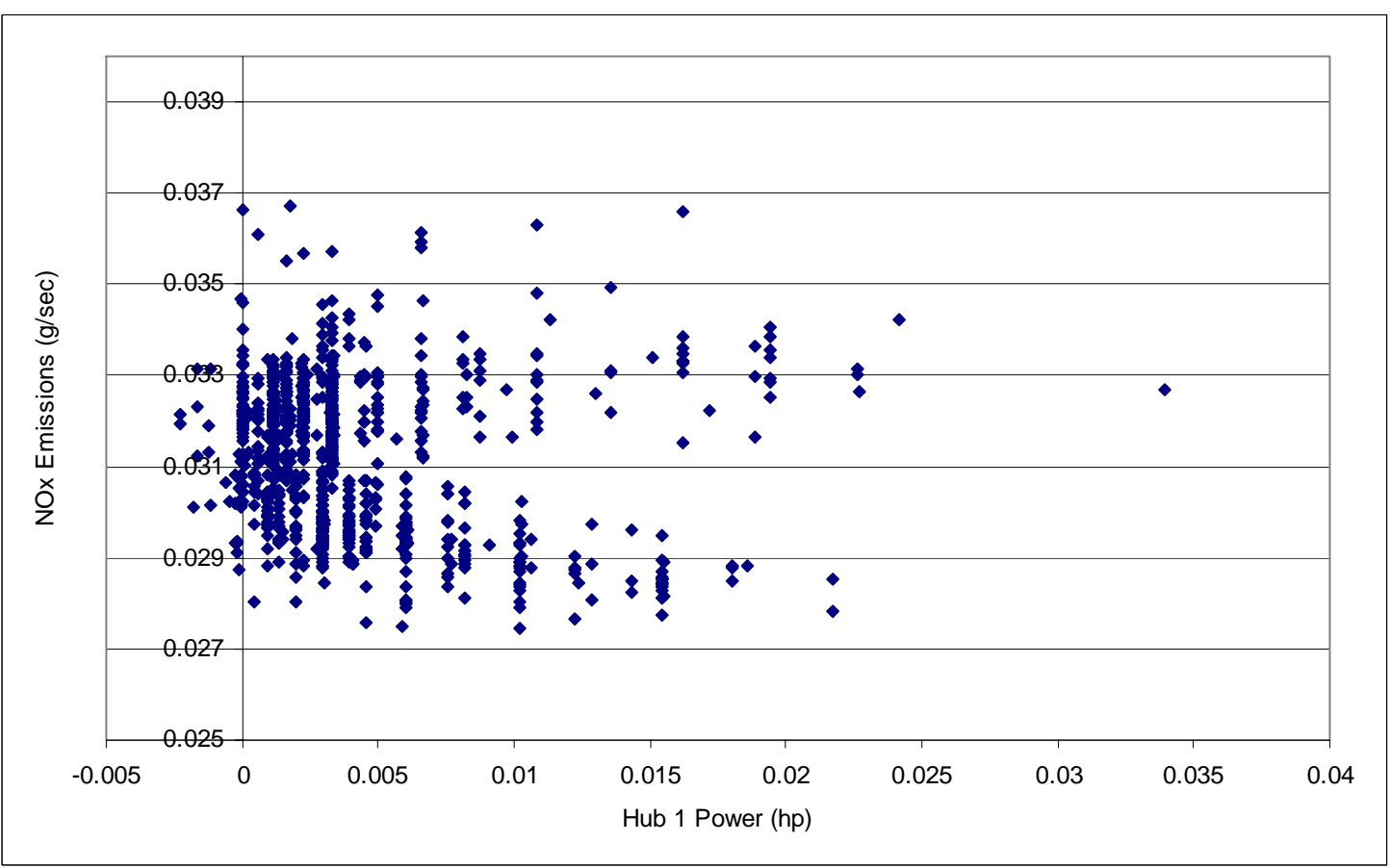

Figure 29: Continuous idle NOx emissions with respect to hub power. Hub power varied from $\mathbf{- 0 . 0 0 2} \mathrm{hp}$ to $0.035 \mathrm{hp}$ during idling 


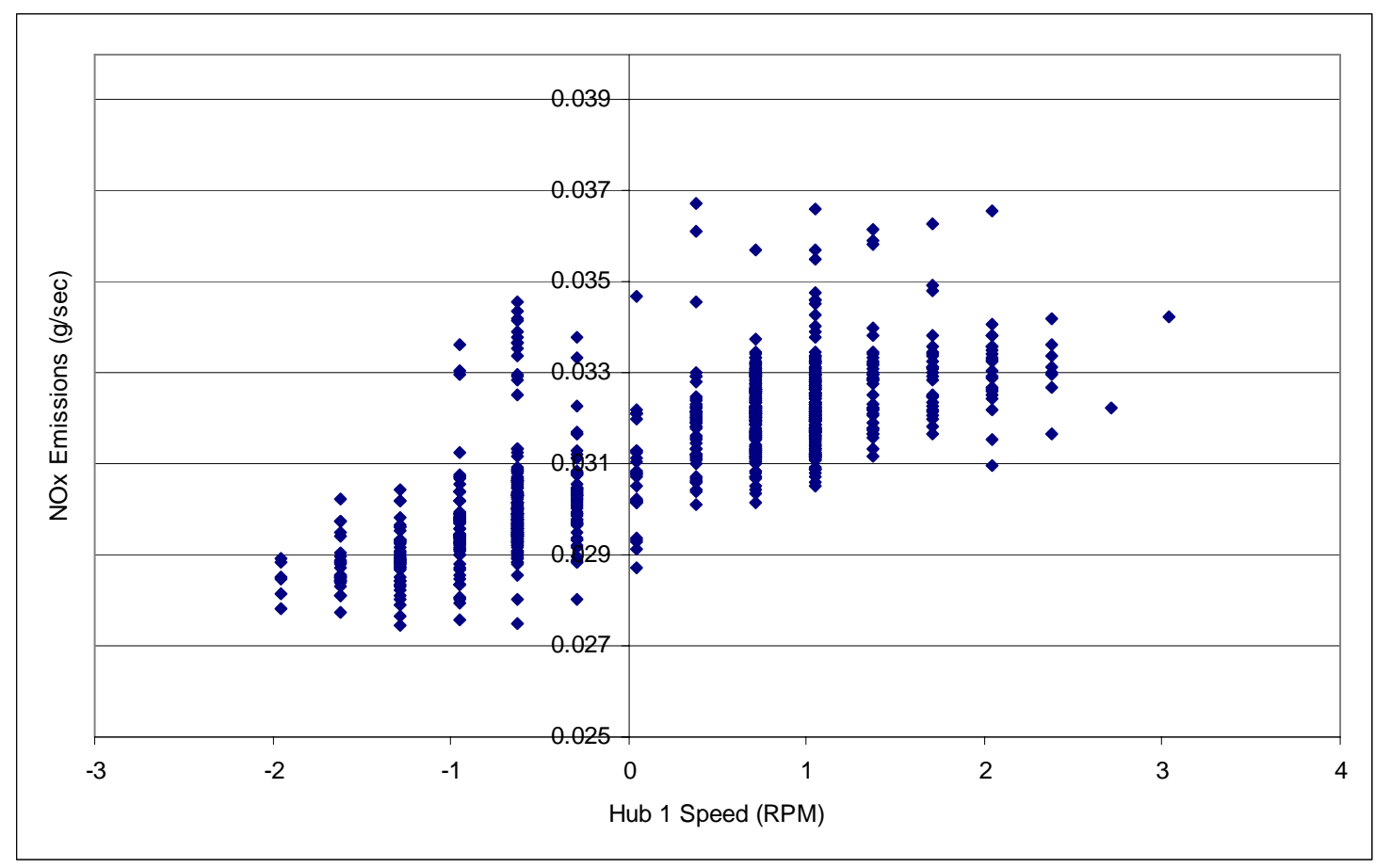

Figure 30: Continuous idle NOx emissions with respect to hub speed. Hub speed varied from -2 rpm to 3.2 rpm during idling

Table 5: Idle CO, HC, NOx, and $\mathrm{CO}_{2}$ Emissions from the Transient Mode and Idle Cycle

\begin{tabular}{|l|l|l|l|l|l|l|l|l|l|}
\hline \multirow{2}{*}{$\begin{array}{l}\text { Name of } \\
\text { truck }\end{array}$} & $\begin{array}{l}\text { Engine } \\
\text { Model } \\
\text { Year }\end{array}$ & \multicolumn{2}{|c|}{ Idle CO (g/hr) } & \multicolumn{2}{|c|}{ Idle HC (g/hr) } & \multicolumn{2}{|c|}{ Idle NOx (g/hr) } & \multicolumn{2}{|c|}{ Idle CO $\mathbf{C O}_{2}$ (g/hr) } \\
\cline { 3 - 10 } & Transient & Idle & Transient & Idle & Transient & Idle & Transient & Idle \\
\hline $\begin{array}{c}\text { E55CRC- } \\
24\end{array}$ & 1975 & 52.76 & 19.96 & 27.94 & 17.68 & 33.98 & 36.40 & 5718 & 3960 \\
\hline $\begin{array}{c}\text { E55CRC- } \\
13\end{array}$ & 1978 & 94.70 & 30.60 & 21.95 & 12.60 & 30.93 & 30.60 & 29205 & 3780 \\
\hline $\begin{array}{c}\text { E55CRC- } \\
16\end{array}$ & 1979 & 56.98 & 40.00 & 14.00 & 5.96 & 53.62 & 64.40 & 4062 & 3780 \\
\hline $\begin{array}{c}\text { E55CRC- } \\
23\end{array}$ & 1983 & 52.10 & 40.40 & 38.80 & 38.68 & 27.97 & 42.40 & 5098 & 5532 \\
\hline $\begin{array}{c}\text { E55CRC- } \\
25\end{array}$ & 1983 & 34.49 & 19.60 & 27.46 & 22.72 & 20.55 & 30.40 & 4551 & 4124 \\
\hline $\begin{array}{c}\text { E55CRC- } \\
33\end{array}$ & 1984 & 43.89 & 27.00 & 15.95 & 14.16 & 104.12 & 108.40 & 5154 & 4480 \\
\hline $\begin{array}{c}\text { E55CRC- } \\
3\end{array}$ & 1985 & 9.49 & 87.60 & 30.47 & 24.36 & 18.27 & 24.10 & 3370 & 3232 \\
\hline $\begin{array}{c}\text { E55CRC- } \\
14\end{array}$ & 1985 & 70.28 & 17.40 & 20.35 & 5.58 & 23.97 & 3.60 & 17381 & 3114 \\
\hline $\begin{array}{c}\text { E55CRC- } \\
12\end{array}$ & 1985 & 59.36 & 33.60 & 62.68 & 45.60 & 23.40 & 18.40 & 4275 & 4316 \\
\hline $\begin{array}{c}\text { E55CRC- } \\
15\end{array}$ & 1986 & 49.36 & 31.20 & 60.02 & 32.40 & 11.93 & 26.00 & 5780 & 5764 \\
\hline $\begin{array}{c}\text { E55CRC- } \\
47\end{array}$ & 1986 & 21.57 & 12.12 & 6.17 & 29.10 & 55.76 & 64.80 & 5779 & 5052 \\
\hline $\begin{array}{c}\text { E55CRC- } \\
19\end{array}$ & 1987 & 56.90 & 40.40 & 60.71 & 34.40 & 12.53 & 26.80 & 3913 & 4440 \\
\hline E55CRC- & 1990 & 15.26 & 9.16 & 2.53 & 3.64 & 62.93 & 82.00 & 4248 & 4000 \\
\hline
\end{tabular}




\begin{tabular}{|c|c|c|c|c|c|c|c|c|c|}
\hline 7 & & & & & & & & & \\
\hline $\begin{array}{c}\text { E55CRC- } \\
21\end{array}$ & 1990 & 44.49 & 38.40 & 8.83 & 4.08 & 100.00 & 101.00 & 4656 & 3884 \\
\hline $\begin{array}{c}\text { E55CRC- } \\
18\end{array}$ & 1991 & 47.86 & 42.80 & 26.57 & 31.28 & 68.50 & 73.60 & 5302 & 4436 \\
\hline $\begin{array}{c}\text { E55CRC- } \\
32\end{array}$ & 1991 & 25.16 & 22.16 & 10.71 & 12.10 & 48.58 & 46.60 & 4786 & 5314 \\
\hline $\begin{array}{c}\text { E55CRC- } \\
20\end{array}$ & 1992 & 32.69 & 17.20 & 3.06 & 5.28 & 69.86 & 79.20 & 4455 & 4024 \\
\hline $\begin{array}{c}\text { E55CRC- } \\
17\end{array}$ & 1993 & 12.85 & 4.08 & 5.50 & 7.20 & 75.71 & 48.00 & 4310 & 4212 \\
\hline $\begin{array}{c}\text { E55CRC- } \\
22\end{array}$ & 1993 & 66.23 & 14.18 & 66.08 & 32.60 & 59.11 & 38.00 & 5201 & 2144 \\
\hline $\begin{array}{c}\text { E55CRC- } \\
45\end{array}$ & 1993 & 44.83 & 57.20 & 310.00 & 311.60 & 57.15 & 48.60 & 5323 & 4362 \\
\hline $\begin{array}{c}\text { E55CRC- } \\
49\end{array}$ & 1993 & 21.23 & 12.16 & 5.49 & 2.40 & 54.41 & 62.40 & 5386 & 5152 \\
\hline $\begin{array}{c}\text { E55CRC- } \\
1 \\
\end{array}$ & 1994 & 44.20 & 29.58 & 5.62 & 4.32 & 76.53 & 113.40 & 6962 & 5622 \\
\hline $\begin{array}{c}\text { E55CRC- } \\
43\end{array}$ & 1994 & 13.10 & 27.73 & 2.36 & 4.27 & 49.00 & 69.20 & 3774 & 4291 \\
\hline $\begin{array}{l}\text { E55CRC- } \\
2\end{array}$ & 1995 & 21.94 & 18.16 & 14.03 & 9.44 & 76.53 & 111.20 & 9837 & 5829 \\
\hline $\begin{array}{c}\text { E55CRC- } \\
6\end{array}$ & 1995 & 13.36 & 12.40 & 10.05 & 5.60 & 69.84 & 92.80 & 5994 & 4144 \\
\hline $\begin{array}{c}\text { E55CRC- } \\
8\end{array}$ & 1996 & 21.81 & 17.24 & 8.08 & 7.48 & 57.56 & 81.60 & 5734 & 5604 \\
\hline $\begin{array}{c}\text { E55CRC- } \\
31\end{array}$ & 1997 & 19.83 & 17.92 & 22.74 & 20.28 & 66.50 & 114.00 & 5373 & 4634 \\
\hline $\begin{array}{c}\text { E55CRC- } \\
9\end{array}$ & 1998 & 23.39 & 18.00 & 9.80 & 4.68 & 75.99 & 63.00 & 4788 & 3319 \\
\hline $\begin{array}{c}\text { E55CRC- } \\
10\end{array}$ & 1998 & 50.97 & 25.60 & 4.49 & 5.96 & 73.57 & 85.60 & 4684 & 4704 \\
\hline $\begin{array}{c}\text { E55CRC- } \\
26 \\
\end{array}$ & 1998 & 27.92 & 17.60 & 6.70 & 3.96 & 38.64 & 60.60 & 4341 & 4242 \\
\hline $\begin{array}{c}\text { E55CRC- } \\
28\end{array}$ & 1998 & 0.00 & 35.40 & 11.03 & 2.42 & 44.27 & 82.00 & 4938 & 3522 \\
\hline $\begin{array}{c}\text { E55CRC- } \\
30\end{array}$ & 1998 & 35.44 & 44.40 & 0.00 & 0.00 & 103.86 & 124.20 & 6251 & 5254 \\
\hline $\begin{array}{c}\text { E55CRC- } \\
48\end{array}$ & 1998 & 13.14 & 13.84 & 17.55 & 0.66 & 137.58 & 196.20 & 7957 & 7152 \\
\hline $\begin{array}{c}\text { E55CRC- } \\
27\end{array}$ & 1999 & 44.29 & 27.80 & 3.59 & 2.90 & 66.70 & 150.40 & 5517 & 5450 \\
\hline $\begin{array}{c}\text { E55CRC- } \\
29 \\
\end{array}$ & 1999 & 31.33 & 17.16 & 19.93 & 13.36 & 44.63 & 40.80 & 7041 & 5322 \\
\hline $\begin{array}{c}\text { E55CRC- } \\
4 \\
\end{array}$ & 2000 & 12.47 & 19.20 & 5.10 & 4.20 & 116.66 & 97.80 & 4573 & 4993 \\
\hline $\begin{array}{c}\text { E55CRC- } \\
5 \\
\end{array}$ & 2000 & 13.80 & 13.72 & 13.75 & 11.12 & 63.88 & 103.20 & 4903 & 6240 \\
\hline $\begin{array}{c}\text { E55CRC- } \\
11\end{array}$ & 2000 & 14.42 & 13.92 & 7.86 & 6.04 & 43.47 & 50.60 & 3387 & 3128 \\
\hline $\begin{array}{c}\text { E55CRC- } \\
35\end{array}$ & 2000 & 22.96 & 25.60 & 9.24 & 7.64 & 68.12 & 80.00 & 4763 & 5124 \\
\hline $\begin{array}{c}\text { E55CRC- } \\
36\end{array}$ & 2001 & 23.42 & 17.94 & 5.57 & 5.90 & 55.71 & 76.00 & 5332 & 5984 \\
\hline $\begin{array}{c}\text { E55CRC- } \\
34 \\
\end{array}$ & 2003 & 23.76 & 21.60 & 4.80 & 2.50 & 26.89 & 91.00 & 3952 & 4198 \\
\hline $\begin{array}{c}\text { E55CRC- } \\
38\end{array}$ & 2003 & 26.89 & 37.54 & 9.34 & 9.36 & 24.37 & 20.40 & 5566 & 5110 \\
\hline $\begin{array}{c}\text { E55CRC- } \\
39 \\
\end{array}$ & 2003 & 10.57 & 7.72 & 6.40 & 6.68 & 21.31 & 67.60 & 5712 & 5220 \\
\hline $\begin{array}{c}\text { E55CRC- } \\
40 \\
\end{array}$ & 2003 & 6.33 & 8.28 & 2.73 & 2.81 & 33.98 & 77.87 & 5010 & 4027 \\
\hline
\end{tabular}




\section{Comparing Idle Emissions Calculated from the Transient Mode with Measured Idle Emissions}

Idle $\mathrm{CO}, \mathrm{HC}, \mathrm{NOx}$, and $\mathrm{CO}_{2}$ emissions obtained from the continuous emissions of the Transient mode as mentioned above and the idle $\mathrm{CO}, \mathrm{HC}, \mathrm{NOx}$, and $\mathrm{CO}_{2}$ emissions obtained from the idle cycles are graphically presented in Figure 31, Figure 32, Figure 33, and Figure 34 respectively. Emissions values are presented according to the engine MY in order to observe the effect of MY on variations on idle emissions from the Transient mode and idle cycles.

Overall, the idle CO obtained from the Transient mode was higher than the $\mathrm{CO}$ emissions from the idle cycle (58\% on average). Variations between the two sets of values were higher for the MY 1975-1990 vehicles than the variation observed for the post 1990 MY vehicles. Average increase in idle CO from the Transient mode for the MY 1975-1990 vehicles was about $86 \%$, while this value dropped to $44 \%$ for the post 1990 MY vehicles. A similar observation has been found for the $\mathrm{CO}_{2}$ emissions, where, average variation for the MY 1975-1990 vehicles was about 88\% but dropped to $16 \%$ for the post $1990 \mathrm{MY}$ vehicles. Overall idle $\mathrm{CO}_{2}$ obtained from the Transient mode has been higher than the values obtained from the idle cycles (39\% on average). High values during the Transient mode could be attributed to some accessory loadings such as fans and compressors and possible inclusion of emissions at the initial acceleration while evaluating emissions from the Transient mode. CRC-13 and CRC-14 trucks showed very high variation between the two values for both the $\mathrm{CO}$ and $\mathrm{CO}_{2}$ emissions. Idle $\mathrm{CO}_{2}$ and $\mathrm{CO}$ emissions from the Transient mode for the CRC-13 truck varied by about $670 \%$ and $190 \%$ respectively while this variation was about $460 \%$ and $290 \%$ respectively for CRC-14 truck. A significant variation has been observed on idle $\mathrm{CO}$ emissions from the $\mathrm{CRC}-12$ truck, which were found to emit $403 \%$ more idle $\mathrm{CO}$ in the Transient mode.

Idle $\mathrm{HC}$, like $\mathrm{CO}$ and $\mathrm{CO}_{2}$ from the Transient mode was higher than the values obtained from the idle cycles. However, variations in the 1975-1990 MY vehicles were less than the variations in the post 1990 MY vehicles. Extremely high variation has been observed 
for the CRC-48 truck. Idle HC from the Transient mode was $17.55 \mathrm{~g} / \mathrm{hr}$ while it was 0.66 $\mathrm{g} / \mathrm{hr}$ from the idle cycle. Idle NOx, obtained from the Transient mode, in contrast to CO, $\mathrm{HC}$, and $\mathrm{CO}_{2}$ emissions were less than the NOx emissions obtained from the idle cycles. Idle NOx obtained from the Transient mode was less than the NOx from the idle cycles for almost all trucks with 1975-1990 MY except CRC-12, CRC-13, and CRC-14 trucks. Out of these three trucks, idle NOx obtained from the Transient mode was 565\% higher than the NOx from the idle cycles for CRC-4 truck. NOx obtained from the Transient mode for the post 1990 MY trucks, on average, was less than the NOx obtained from the idle cycles. High values of NOx from the idle cycles could be attributed to the advance injection timing employed at idle.

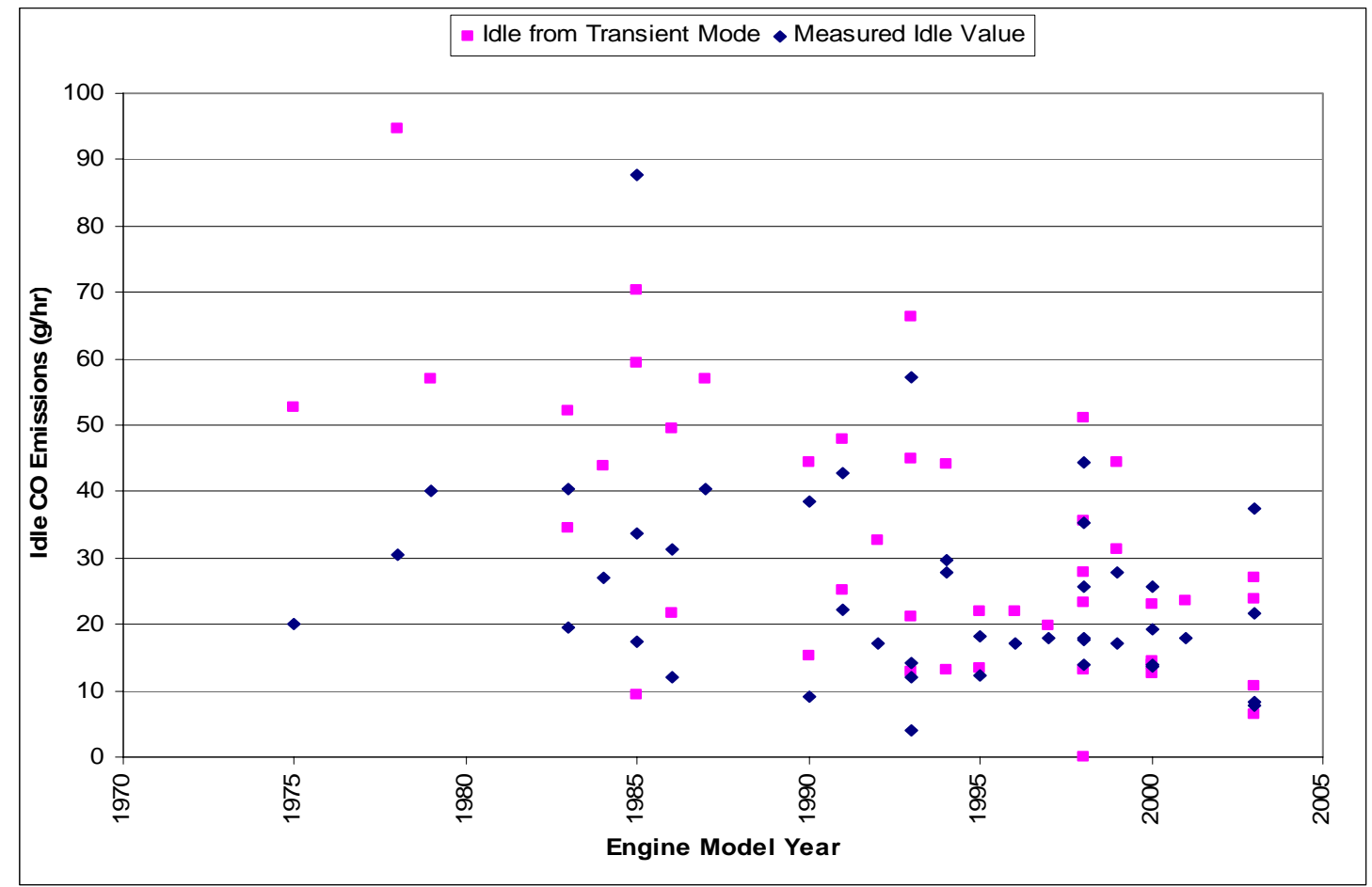

Figure 31: Variation of idle CO obtained from the Transient mode and values from the idle cycles with Engine MY 


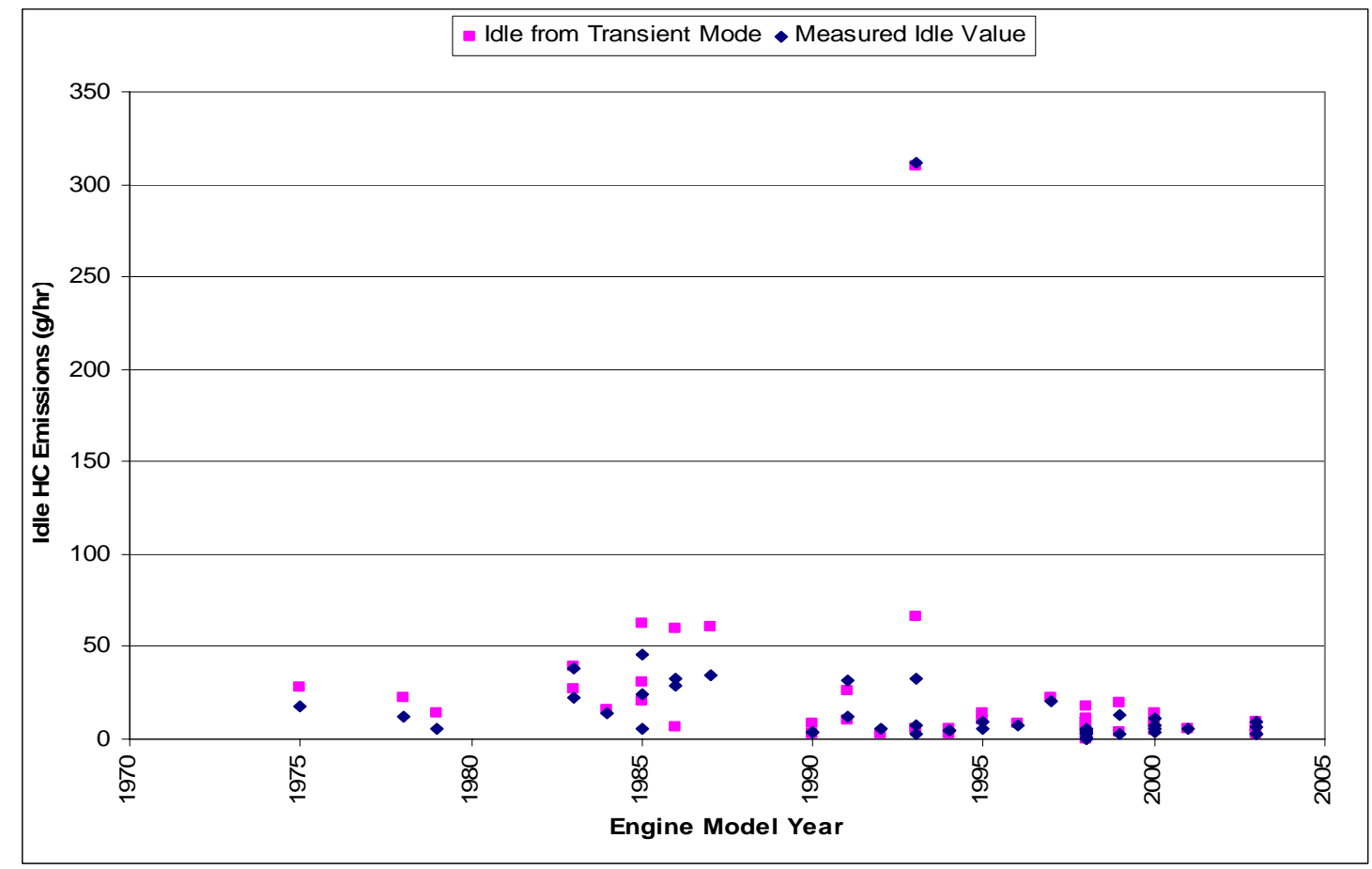

Figure 32: Variation of idle HC obtained from the Transient mode and values from the idle cycles with Engine MY

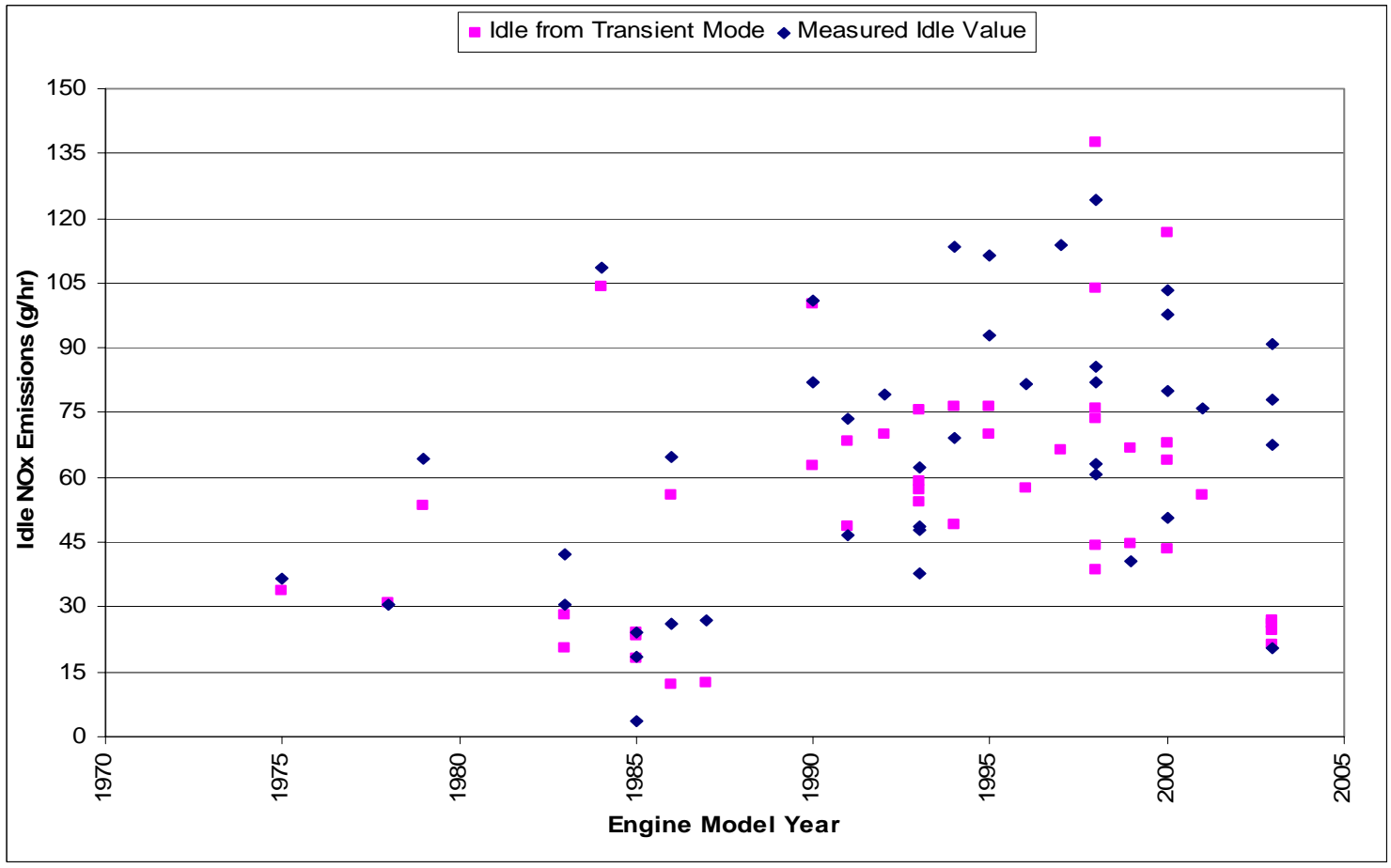

Figure 33: Variation of idle NOx obtained from the Transient mode and values from the idle cycles with Engine MY 


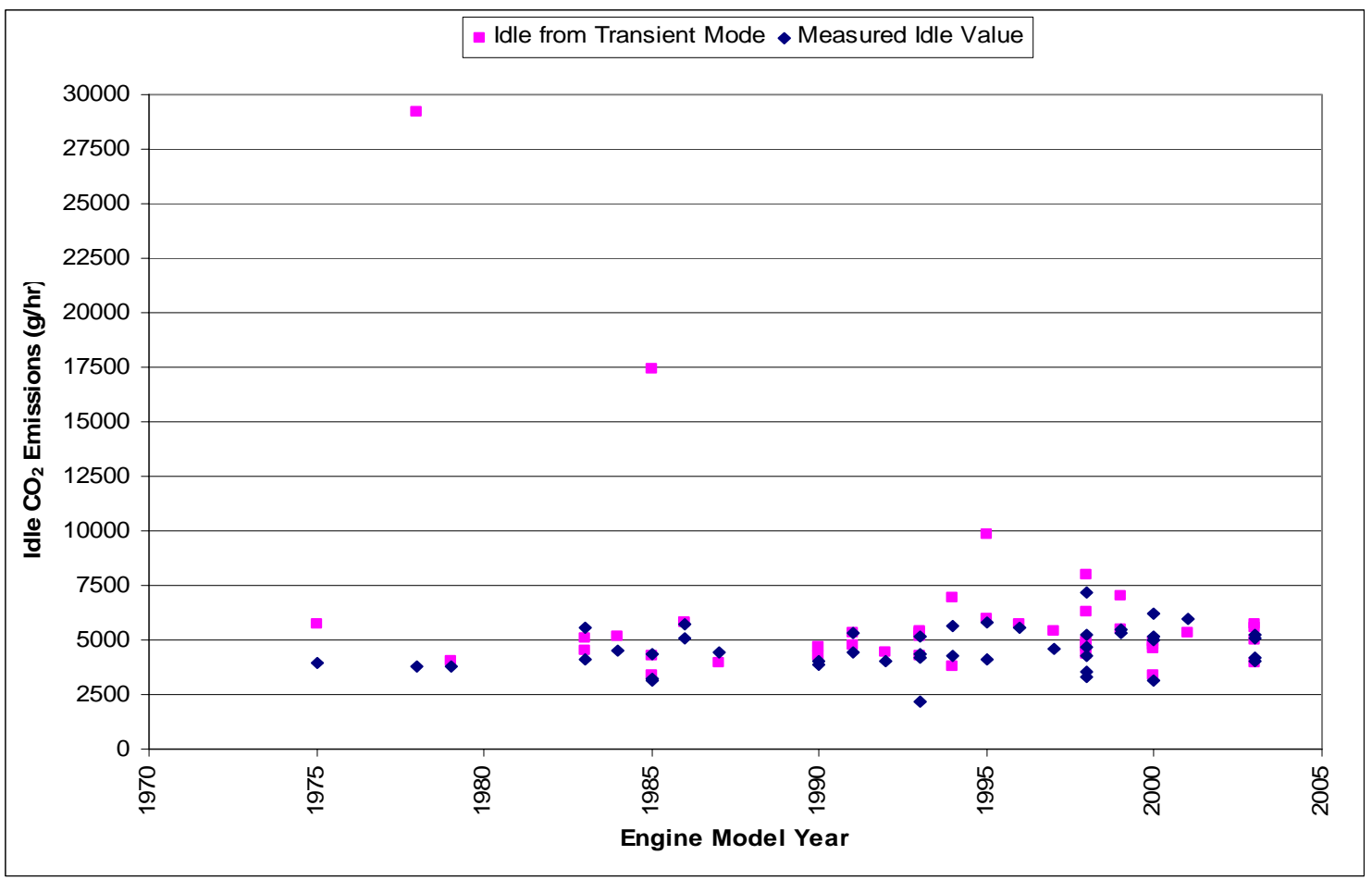

Figure 34: Variation of idle $\mathrm{CO}_{2}$ obtained from the Transient mode and values from the idle cycles with Engine MY

\section{ENGINE IDLE EMISSIONS}

Perhaps this study would not have achieved completeness unless idle emissions obtained from chassis dynamometer testing had been compared and contrasted with idle data obtained from engine certification testing. Engines have been tested in the test cell of WVU Center for Alternative Fuels, Engines, and Emissions (CAFEE). This test cell is equipped with the state-of-the-art engine test equipment and was capable of measuring heavy-duty engines exhaust emissions in accordance with the Code of Federal Regulations (CFR) [20].

Two sets of data were procured from two different engine certification tests. In the first set, idle emissions from six engines tested on the FTP cycle has been compiled. Details of the tested engines are presented in Table 6. 
Table 6: Type, Model Year, and Displacement of the Tested Engines

\begin{tabular}{|l|l|l|l|}
\hline Engine Name & Model Year (MY) & Engine Type & $\begin{array}{l}\text { Displacement } \\
(\text { Liter })\end{array}$ \\
\hline Engine 1 & 1992 & DDC Series 60 & 12.7 \\
\hline Engine 2 & Engine 1 with rebuilt head and new set of injectors \\
\hline Engine 3 & 1991 & DDC Series 60 & 11.1 \\
\hline Engine 4 & 1991 & DDC Series 60 & 12.7 \\
\hline Engine 5 & 2000 & DDC Series 60 & 12.7 \\
\hline Engine 6 & 1995 & DDC Series 60 & 12.7 \\
\hline
\end{tabular}

Idle emissions were extracted from three idle segments of the FTP cycle, at the beginning (0-20 seconds), from 280-300 seconds, and 905-925 seconds of the FTP cycle. Engine 1 was tested with Type 2-D diesel, Engine 2, Engine 4, Engine 5, and Engine 6 were tested with CARB specified diesel, whereas, Engine 3 was tested with Shell diesel. First four engines were tested for hot idle while Engine 5 and Engine 6 were tested for warm idle. Average idle emissions of $\mathrm{CO}, \mathrm{NOx}, \mathrm{HC}$, and $\mathrm{CO}_{2}$ from each engine are presented in Figure 35. Error bars represent \pm 1 standard deviations between idle emissions measured in three different idle segments of the FTP test. PM emissions could not be evaluated from these sets of engines. CO emissions ranged from $12 \mathrm{~g} / \mathrm{hr}$ to $68 \mathrm{~g} / \mathrm{hr}$ when tested for hot idle, averaging $29 \mathrm{~g} / \mathrm{hr}$ from all engines. Hot idle $\mathrm{HC}$ emissions varied from $1.7 \mathrm{~g} / \mathrm{hr}$ to $8.3 \mathrm{~g} / \mathrm{hr}$. The average $\mathrm{HC}$ emissions from first four engines were found to be $4.8 \mathrm{~g} / \mathrm{hr}$. Idle $\mathrm{NOx}$ and $\mathrm{CO}_{2}$ emissions from the engines for hot idle varied from $49.3 \mathrm{~g} / \mathrm{hr}$ to 95.5 $\mathrm{g} / \mathrm{hr}$ and $2680 \mathrm{~g} / \mathrm{hr}$ to $3426 \mathrm{~g} / \mathrm{hr}$ respectively and the average $\mathrm{NOx}$ and $\mathrm{CO}_{2}$ were found to be $72.5 \mathrm{~g} / \mathrm{hr}$ and $3095 \mathrm{~g} / \mathrm{hr}$ respectively. Engine 5 and Engine 6 emitted high NOx (90 $\mathrm{g} / \mathrm{hr}$ and $126 \mathrm{~g} / \mathrm{hr}$ respectively) and $\mathrm{CO}_{2}(4896 \mathrm{~g} / \mathrm{hr}$ and $8100 \mathrm{~g} / \mathrm{hr}$ respectively) at the start of the FTP cycle. These values sharply reduced during the 280-300 seconds segment but increased during the 905-925 seconds segment. This pattern has not been observed for the first four engines, which were tested for hot idle. Therefore, emissions data from 
Engine 5 and Engine 6 have been excluded when average engine idle emissions are presented.

In the second set, Engine 2 of the first test set was tested on the FTP cycle and idle emissions data of $\mathrm{CO}, \mathrm{HC}, \mathrm{NOx}, \mathrm{PM}$ and $\mathrm{CO}_{2}$ for the first 240 seconds were collected and reported in $\mathrm{g} / \mathrm{hr}$. This engine was tested with CARB specified diesel. Average emissions of $\mathrm{CO}$, NOx, $\mathrm{HC}, \mathrm{PM}$, and $\mathrm{CO}_{2}$ were found to be $31.13 \mathrm{~g} / \mathrm{hr}, 84.27 \mathrm{~g} / \mathrm{hr}, 4.92$ $\mathrm{g} / \mathrm{hr}, 0.84 \mathrm{~g} / \mathrm{hr}$, and $4117.9 \mathrm{~g} / \mathrm{hr}$ respectively. Figure 36 shows the idle emissions from Engine 2.

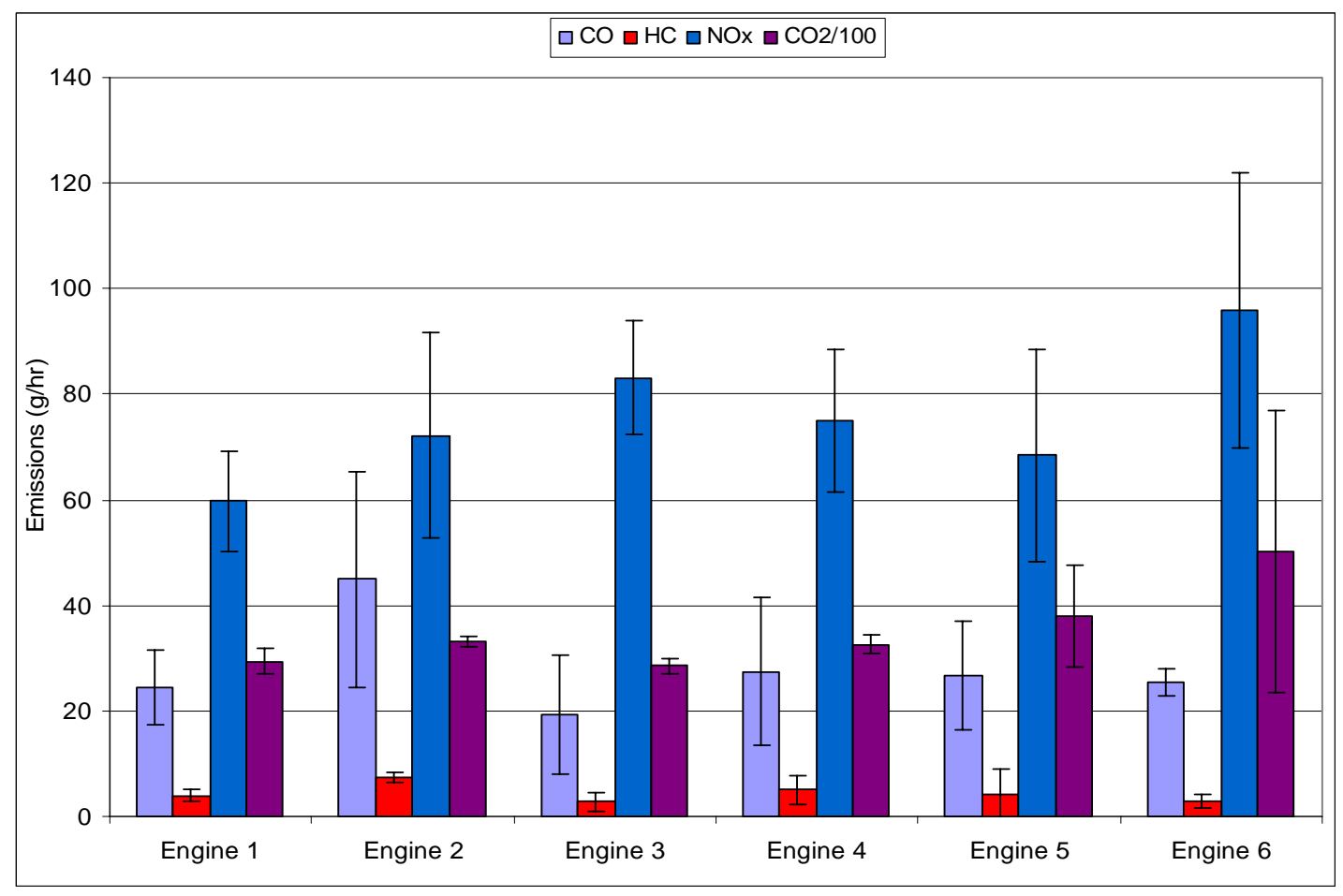

Figure 35: Engine idle emissions from six DDC Series 60 Engines 


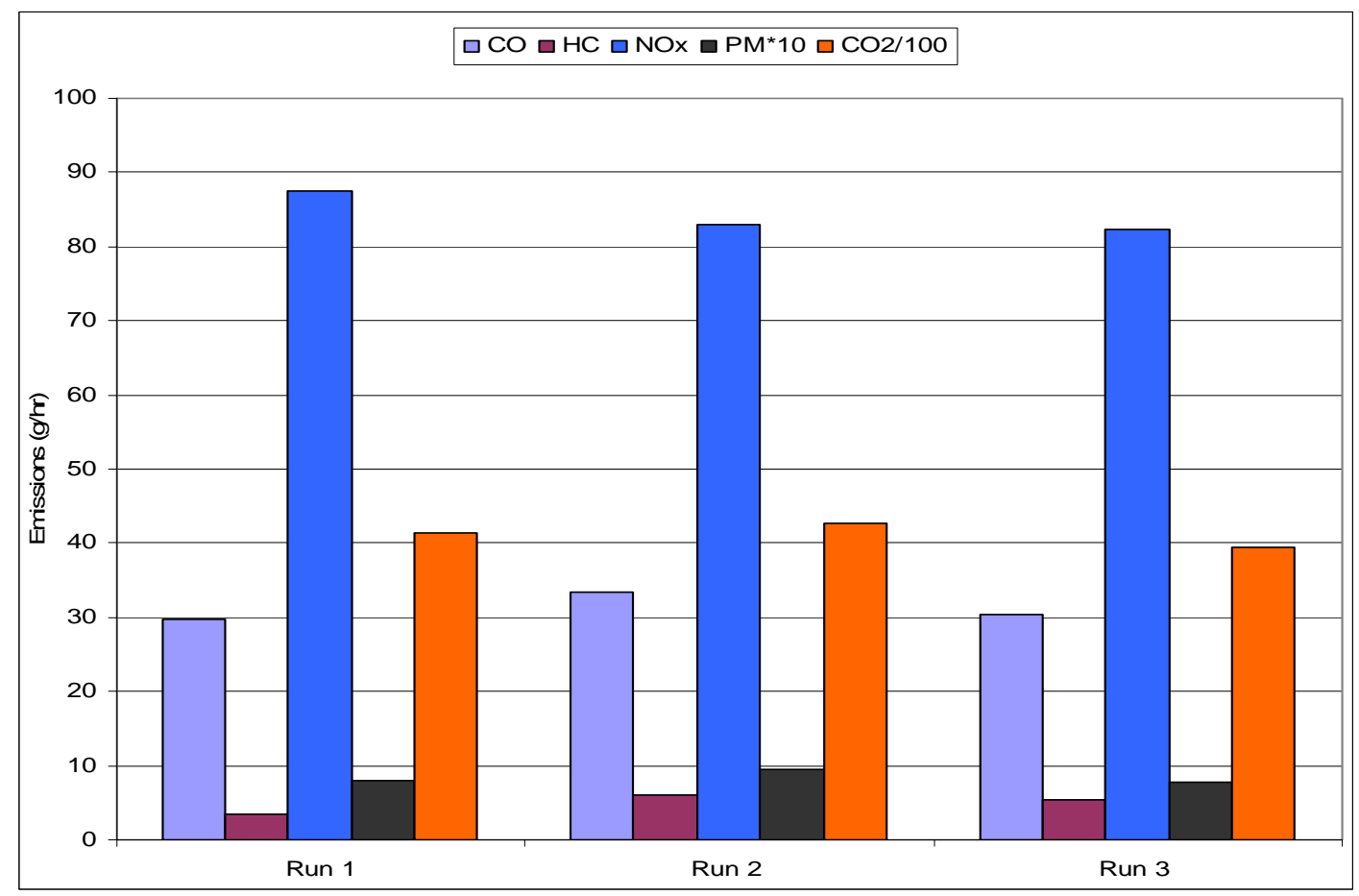

Figure 36: Engine idle emissions including PM from Engine 2

\section{COMPARISON OF IDLE EMISSIONS MEASURED BY WVU WITH OTHER IDLE EMISSIONS DATA}

Idle emissions data procured from the vehicles and engines idle emissions test program conducted by the WVU Translab and CAFEE are compared and contrasted with idle emissions available in literature. Comparison of idle emissions from various types of vehicle groups with different fuel types is neither simple nor conclusive because of the differences in vehicle pattern, MY, vehicle miles traveled (VMT) and ambient conditions on which the vehicles were tested. The comparison has been presented in Table 7, which takes into consideration the idle data from EMFAC 2000 (Both the summer and the winter data) [7], EMFAC 2002, version 2.2 [29], WVU vehicle idle data for MY 1975-1990 and post 1990 MY, WVU engine idle data, and other idle data available in literature [2, 4, 7-11]. 
EMFAC 2002 (version 2.2) has been developed from the E-55/59 Study conducted by WVU. Therefore, a strong similarity could be observed between these data. A similar pattern has been observed between the idle emissions reported by the ANL [4] and that presented on the EMFAC 2000 model for the summer and the winter condition [7]. ANL data included the effect of heating/cooling and elevated engine speed. Therefore, emissions data from the ANL Study was likely to differ from the other studies, which might not have included the heating or cooling load effects on idle emissions. Idle CO emissions from all studies were found to have similarity except from the ANL study and data obtained by McCormick et al [8]. Idle HC emissions varied from minimum $4.0 \mathrm{~g} / \mathrm{hr}$ to maximum $25 \mathrm{~g} / \mathrm{hr}$ for HDDV. Idle $\mathrm{HC}$ emissions from CNG buses were very high (86.1 $\mathrm{g} / \mathrm{hr})$, although $\mathrm{HC}$ from the $\mathrm{CNG}$ engines are primarily methane [30]. NOx and PM emissions were found be coherent amongst all studies with later MY engines emitting comparatively higher NOx but very low PM. $\mathrm{CO}_{2}$ emissions and fuel consumption from the literature had limited variation except the ANL data, in which the $\mathrm{CO}_{2}$ emissions and fuel consumption were approximately twice than the $\mathrm{CO}_{2}$ emissions and fuel consumption in other studies. Idle emissions in the literature might include cooling fan, air compressor, air conditioner, and alternator loads, which can cause substantial variability in data collection.

Table 7: Comparison of Engine and Tailpipe Idle Emissions, and Fuel Consumption from WVU and Available Data

\begin{tabular}{|l|c|c|c|c|c|l|l|}
\hline Source & $\begin{array}{l}\text { CO } \\
(\mathbf{g} / \mathbf{h r})\end{array}$ & $\begin{array}{l}\mathbf{H C} \\
(\mathbf{g} / \mathbf{h r})\end{array}$ & $\begin{array}{l}\mathbf{N O x} \\
\mathbf{( g / h r})\end{array}$ & $\begin{array}{l}\mathbf{P M} \\
\mathbf{( g / h r})\end{array}$ & $\begin{array}{l}\mathbf{C O}_{2} \\
(\mathbf{g} / \mathbf{h r})\end{array}$ & $\begin{array}{l}\text { Fuel } \\
(\mathbf{g a l} / \mathbf{h r})\end{array}$ & Comments \\
\hline $\begin{array}{l}\text { EMFAC 2000 } \\
\text { Model }\end{array}$ & 94 & 12.5 & 55 & 2.57 & N/A & N/A & Summer $\left(75^{\circ} \mathrm{F}\right)$ \\
\hline $\begin{array}{l}\text { EMFAC 2000 } \\
\text { Model }\end{array}$ & 94.6 & 12.6 & 56.7 & 2.57 & N/A & N/A & Winter $\left(30^{\circ} \mathrm{F}\right)$ \\
\hline $\begin{array}{l}\text { EMFAC 2002 } \\
\text { Model }\end{array}$ & 26.3 & 3.48 & 80.7 & $1.004^{*}$ & 4098 & N/A & $* 1994+$ \\
\hline $\begin{array}{l}\text { WVU Vehicle } \\
\text { Idle data }\end{array}$ & $\mathbf{2 3 . 3 2}$ & $\mathbf{9 . 5}$ & $\mathbf{8 3 . 3 1}$ & $\mathbf{1 . 4 1}$ & $\mathbf{4 6 1 4}$ & $\mathbf{0 . 4 7}$ & $\mathbf{M Y ~ 1 9 9 1 - 2 0 0 4}$ \\
\hline $\begin{array}{l}\text { WVU Vehicle } \\
\text { Idle data }\end{array}$ & $\mathbf{3 1 . 3 1}$ & $\mathbf{2 1 . 0 6}$ & $\mathbf{4 7 . 7 6}$ & $\mathbf{3 . 8 0}$ & $\mathbf{4 5 0 4}$ & $\mathbf{0 . 4 6}$ & $\mathbf{M Y ~ 1 9 7 5 - 1 9 9 0}$ \\
\hline
\end{tabular}




\begin{tabular}{|c|c|c|c|c|c|c|c|}
\hline $\begin{array}{l}\text { WVU Engine } \\
\text { Idle data }\end{array}$ & 29.46 & 4.84 & 74.88 & 0.84 & 3300 & 0.36 & Post 1990 Model \\
\hline ANL [4] & 94.6 & 12.6 & 56.7 & 2.57 & 10397 & $1.0^{*}$ & $\begin{array}{l}* \text { With Heating/Air } \\
\text { condition }\end{array}$ \\
\hline $\begin{array}{l}\text { Brodrick et al. } \\
\text { [9] }\end{array}$ & 14.6 & 1.8 & 103 & $\mathrm{n} / \mathrm{a}$ & 4034 & 0.36 & Idling after cruise \\
\hline $\begin{array}{l}\text { Brodrick et al. } \\
{[9]}\end{array}$ & 15.9 & 2.9 & 105 & $\mathrm{n} / \mathrm{a}$ & 4472 & 0.39 & Idling after transient \\
\hline Han Lim [2] & $\mathrm{n} / \mathrm{a}$ & $\mathrm{n} / \mathrm{a}$ & 84.54 & $\mathrm{n} / \mathrm{a}$ & 4256 & 0.42 & 1995 International \\
\hline Pekula et al. [11] & $\mathrm{n} / \mathrm{a}$ & $\mathrm{n} / \mathrm{a}$ & 97 & & 5170 & 0.46 & $600 \mathrm{RPM}, 65^{\circ} \mathrm{F}$ \\
\hline Storey et al. [10] & 29.8 & 25.2 & 78.6 & 0.85 & 4720 & 0.4 & $\begin{array}{l}600 \mathrm{RPM}, 65^{\circ} \mathrm{F}, \\
2001 \text { Freightliner }\end{array}$ \\
\hline $\begin{array}{l}\text { McCormick et } \\
\text { al. [8] }\end{array}$ & 79.56 & 8.22 & 120.9 & 2.8 & N/A & N/A & Diesel bus average \\
\hline $\begin{array}{l}\text { McCormick et } \\
\text { al. [8] }\end{array}$ & 67.14 & 86.1 & 16.02 & 0.18 & N/A & N/A & $\mathrm{CNG}$ bus average \\
\hline
\end{tabular}

\section{CONCLUSIONS}

Idle emissions from the heavy-duty diesel buses and trucks are not desirable because of their effects on economy, environment, and human health. Long haul trucks are found to idle at truck stops for an extended period primarily for the heating and air conditioning of the drivers' cabin, which cannot simply be proscribed because of the annual temperature profile in the USA. These trucks, in addition to adding criteria pollutants to the ambient environment, consumed millions of gallons of diesel fuel during idling. Idling also reduces engine life, and increases maintenance cost. A comprehensive database on idling emissions and fuel consumption is not available at present, although some studies were conducted to quantify idle emissions on a limited scale. Therefore, in order to create a comprehensive idle database, WVU tested over sixty heavy-duty diesel buses and trucks during the E-55/59 Study sponsored by the U.S. Department of Energy (DOE) Office of FreedomCAR and Vehicle Technologies through the National Renewable Energy Laboratory (NREL), the Coordinating Research Council Inc. (CRC), California Air 
Resources Board (CARB), U.S. Environmental Protection Agency (USEPA), and the South Coast Air Quality Management District, and the Engine Manufacturers Association and the Gasoline-Diesel PM Split Study, sponsored by the US Department of Energy (DOE) Office of FreedomCAR and Vehicle Technologies through the NREL.

Idle emissions data for regulated pollutants like $\mathrm{CO}, \mathrm{HC}$, NOx, and $\mathrm{PM}$ have been collected, compiled, and reported in $\mathrm{g} / \mathrm{hr}$ form a total of sixty six heavy-duty diesel vehicles consisted of sixty four trucks having $30,000 \mathrm{lbs}$ or more GVW and two heavyduty 2-stroke diesel buses. Out of these sixty-six HDDV, forty-eight trucks were tested during the E-55/59 Study and sixteen trucks and two buses were tested during the PM Split Study. Idle $\mathrm{CO}_{2}$ emissions and fuel consumption for all these buses and trucks were also evaluated and reported in $\mathrm{g} / \mathrm{hr}$ and $\mathrm{gal} / \mathrm{hr}$ respectively. All these data were compared and contrasted with engine MY in order to observe their trend and identify possible effects on idle emissions from the remarkable advancement in automotive industry during the 90s. In addition, effect of elevated engine speed and accessory loadings such as $\mathrm{A} / \mathrm{C}$ was observed. Idle emissions were also obtained from the continuous data of the Transient mode of the HHDDT Schedule. To give a sense of completeness vehicle idle emissions data were than compared with engine idle emissions data. This comparison provided the opportunity to compare and contrast engine idle emissions and real-world emissions from the vehicles. Finally, these data were compared with idle data available in literature, which is expected to provide a common platform in assessing idle emissions from old and new generation heavy-duty diesel buses and trucks.

It has been observed that ambient temperature and humidity along with difference in engine technologies were responsible for higher test-to-test variations. $\mathrm{NOx} / \mathrm{CO}_{2}$ ratio for the post $1990 \mathrm{MY}$ vehicles was found to be high than the $\mathrm{NOx} / \mathrm{CO}_{2}$ ratio of the MY 1975-1990 vehicles. It indicated that manufacturer of these vehicles had advanced the timing of injection in order to ensure stability in idle and to avoid white smoking at light load or low temperature. It has also been observed that idle emissions varied with engine $\mathrm{MY}$. Idle $\mathrm{CO}, \mathrm{HC}$ and PM emissions were found to decrease with increasing engine MY in contrast to the idle NOx emissions, which increased with increasing engine MY 
because the modern electronic diesel engines control strategy provides for the advanced injection timing that increases NOx. Idle $\mathrm{CO}_{2}$ emissions and fuel consumption from the tested vehicles were found to remain almost constant over the period. For one truck of MY 2003, the effect of air conditioning and elevated engine speed was observed and it was found that $\mathrm{CO}_{2}, \mathrm{NOx}, \mathrm{PM}$, and fuel consumption increased by $25 \%, 30 \%, 20 \%$, and $27 \%$ respectively with the use of $\mathrm{A} / \mathrm{C}$ at $600 \mathrm{rpm}$ engine speed and elevating the idle engine speed from $600 \mathrm{rpm}$ to $1100 \mathrm{rpm}$ caused an increase in $\mathrm{CO}_{2}, \mathrm{NOx}, \mathrm{PM}$, and fuel consumption by $165 \%, 225 \%, 76 \%$, and $170 \%$ respectively. Two 2 -stroke diesel buses of MY 1982 and MY 1992 were tested during the PM Split Study and the third bus (MY 2000) was recently tested during the Transit Vehicle Exhaust Emissions Evaluation project, which has been sponsored by the US Department of Transportation, Federal Transit Administration. All emissions from the two 2-stroke diesel buses were higher than the MY 2000 bus except NOx, which was high for the MY 2000 bus.

Idle emissions were also obtained from the Transient mode of the HHDDT Schedule. These values were obtained from the continuous data of the Transient mode at hub horsepower close to zero. Overall, idle emissions obtained from the Transient mode of the HHDDT Schedule were higher than emissions from the idle cycles except NOx, which was less than NOx emissions from the idle cycles. The high idle values of CO, $\mathrm{HC}$, and $\mathrm{CO}_{2}$ from the Transient mode has been partly due to the effect of some accessory loadings such as fan and the compressors and partly due to the possible inclusion of emissions at initial acceleration while evaluating emissions from the continuous data. NOx emissions from the Transient mode were less than the NOx emissions obtained from the idle cycles, which is due to the advance injection timing during idle.

In addition to the vehicles' idle emissions, engine idle emissions and fuel consumption were also obtained from six DDC Series 60 engines of MY 1991, 1992, 1995, and 2000 in two separate sets, which were tested for fuel certification. These data showed a substantial variation in $\mathrm{NOx}$ and $\mathrm{CO}_{2}$ when tested for warm idle than the variation observed when tested for hot idle. Engines in a test cell were found to consume fuel at 
only $70 \%$ of the level found in the PM Split Study and the E-55/59 data. This is because fan and compressor loads were absent in the test cell. The test cell engines did exhibit CO and NOx emissions similar to the post-1990 vehicles, but emitted PM at about half of the level from the post-1990 vehicles. While comparing these data with other idle data available in literatures, it has been observed that for similar engine and test conditions, they were in close relationship with each other except idle $\mathrm{CO}, \mathrm{NOx}$, and $\mathrm{CO}_{2}$ emissions and idle fuel consumption. Idle emissions in the literature might include cooling fan, air compressor, air conditioner, and alternator loads, which can cause substantial variability in data collection. Variations in the $\mathrm{CO}_{2} /$ fuel consumption ratios might be partly due to correction for engine intake $\mathrm{CO}_{2}$ mass.

This thesis has excellent potential both in terms of emissions inventory and economic implications. These data would provide 'the database' that the market was looking for. It is likely to give an insight into the idle emissions and the effects of engine MY on them. Projecting the effect of accessory loadings would provide an understanding of the increased idle emissions when heating or cooling is used. The thesis would also help in projecting the true potentials of the idle reduction technologies in reducing emissions and fuel consumption during idling.

\section{REFERENCES}

1. Summary of Recommendations, "National Energy Policy - Report of the National Energy Policy Development Group," ISBN 0-16-050814-2, May 2001.

2. Lim, H., "Study of Exhaust Emissions from Idling Heavy Duty Diesel Trucks and Commercially Available Idle-Reducing Devices," SAE Paper 2003-010288 .

3. Brodrick, C.J., Lutsey, N.P., Keen, Q.A., Rubins, D.I., Wallace, J.P., Dwyer, H.A., and Gouse, S.W.III, “Truck Idling Trends: Results of Pilot Survey in Northern California,” SAE Paper 2001-01-2828. 
4. Stodolsky, F., Gaines, L., and Vyas A., "Analysis of Technology Options to Reduce the Fuel Consumption of Idling Trucks," ANL/ESD-43, Argonne National Laboratory, Argonne, Illinois, June 2000.

5. American Transportation Research Institute, "Compendium of Idling Regulations," September 2004.

6. California Air Resources Board, "Heavy-Duty Diesel Idling Control Measure," July 2004.

7. The United States Environmental Protection Agency, "Emission Facts-Idling Vehicle Emissions," EPA 420-F-98-014, April 1998.

8. McCormick, R.L., Graboski, M.S., Alleman, T.L., and Yanowitz, J., "Idling Emissions from Heavy-Duty Diesel and Natural Gas Vehicles at High Altitude," Journal of the Air \& Waste Management Association, Vol. 50, pp.1992-1998, November 2000.

9. Brodrick, C.J., Dwyer, H.A., Farshchi, M., Harris, D.B., and King, F.G. Jr., "Effects of Engine Speed and Accessory Load on Idling Emissions from Heavy-Duty Diesel Truck Engines," Journal of the Air \& Waste Management Association, Vol. 52, pp. 1026-1031, September 2002.

10. Storey, J.M.E., Thomas, J.F., Lewis, S.A. Sr., Dam, T.Q., Edwards, K.D., DeVault, G.L., and Retrossa, D.J., "Particulate Matter and Aldehyde Emissions from Idling Heavy-Duty Diesel Trucks," SAE Paper 2003-01-0289.

11. Pekula, N., Kuritz, B., Hearne, J., Marchese, A.J., and Hesketh, R.P., "The Effect of Ambient Temperature, Humidity and Engine Speed on Idling Emissions from Heavy-Duty Diesel Trucks," SAE Paper 2003-01-0290.

12. Lutsey, N., Brodrick, C.J., Sperling, D., and Lipman, T. "Market Potential of Fuel Cell Auxiliary Power Units in Long-Haul Trucks," $84^{\text {th }}$ Annual Conference, Transportation Research Board (TRB), Washington D.C., 9-13 January 2005.

13. U.S. Environmental Protection Agency, "Idling Reduction Technologies," www.epa.gov/otaq/smartway/idlingtechnologies.htm. Dated April 26, 2005. 
14. Sharke, P., "Idle Hour, Truckers are the Next Target of the Clean Air Force," Mechanical Engineering (ISSN 0025-6501), Vol. 127/No.1, pp. 32-34, January 2005.

15. Clark, N.N., Gautam, M., Wayne, W.S., Lyons, D.W., and Thompson, G., "California Heavy Heavy-Duty Diesel Truck Emissions Characterization for Project E-55/59-1.5," Final Report to the Coordinating Research Council, 2004.

16. Clark, N.N., Wayne, W.S., Lyons, D.W., and Thompson, G., "Gasoline-Diesel PM Split Study: Heavy-Duty Vehicle Exhaust Collection Phase," Final Report submitted to the National Renewable Energy Laboratory (NREL), September 23, 2002.

17. Clark, N.N., Wayne, W.S., Nine, R.D., Lyons, D.W., and Thompson, G.J., "Heavy-Duty Vehicle Exhaust Emissions from the PM Split Study," Draft paper submitted to the Journal of the Air \& Waste Management Association.

18. www.weather.com -Monthly Climatology, "Monthly Averages for Riverside, California," http://www.weather.com/activities/other/other/weather/climomonthly-graph.html?locid=USCA0949\&from=search, Dated May 12, 2005.

19. Riverside, California Detailed Profile - Travel and Real Estate, http://www.city-data.com/city/Riverside-California, Dated May 12, 2005.

20. Code of Federal Regulations, Title 40, Part 86, Sub-part N, "Protection of Environment," U.S. Government Printing Office, 2004.

21. Gautam, M., Clark, N., Lyons, D., Long, T. Jr., Howell, A., Loth, J., Palmer, G.M., Wang, W.G., and Bata, R., "Design Overview of a Heavy Duty Mobile Vehicle Emissions Testing Laboratory," ASME DE - Vol. 40, Advanced Automotive Technologies, pp. 199-207, ASME Winter Annual Meeting, Atlanta, GA, Dec. 1-6, 1991.

22. Lyons, D., Bata, R., Wang, W.G., Clark, N., Palmer, G.M., Gautam, M., Howell, A., Loth, J., and Long, T. Jr., "Design and Construction of a Transportable Heavy Duty Vehicle Emission Test Laboratory," ISATA Paper No. 920450, 25th International Symposium on Automotive Technology and Automation (ISATA), Florence, Italy, June 1-5, 1992. 
23. Automotive diesel fuel regulations, United States 2006 specification, http://www.dieselnet.com/tech/fuels/us auto.html\#y2006, Dated May 12, 2005.

24. Clark, N.N., Gautam, M., Wayne, W.S., Riddle, W., Nine, R.D., Lyons, D.W., and Xu, S., "Examination of Heavy Heavy-Duty Diesel Truck Chassis Dynamometer Schedule," SAE Paper 2004-01-2904.

25. Pulkrabek, W.W., "Engineering Fundamentals of the Internal Combustion Engine," Second Edition, Pearson Prentice-Hall, New Jersey, 2004, Page 340.

26. Wayne, W.S., Clark, N.N., Gautam, M., Thompson, G., and Lyons, D.W., "Natural Gas Heavy-Duty Transit Bus Emissions Testing - Washington Metropolitan Area Transit Authority," Final Report to the National Renewable Energy Laboratory (NREL), 2004.

27. Wayne, W.S., Clark, N.N., Gautam, M., Lyons, D.W., "Transit Bus Emissions Survey: Working Draft," to be submitted to U.S. Department of Transportation, Federal Transit Authority, August 2005.

28. Gautam, M., Clark, N.,N., Riddle, W., Nine, R., Wayne, W.S., Maldonado, H., Agrawal, A., and Carlock, M., "Development and Initial Use of a HeavyDuty Diesel Truck Test Schedule for Emissions Characterization," 2002 SAE Transactions: Journal of Fuels \& Lubricants, Vol. 111, pp. 812-825, SAE 2002-01-1753.

29. California Environmental Protection Agency, Air Resources Board, "Proposal to Reduce Idling from New 2007+ Heavy-Duty Diesel Trucks," Agenda for Public Workshop, June 4, 2003.

30. Clark, N.N., Lyons, D.W., Rapp, B.L., Gautam, M., Wang, W., Norton, P., White, C., and Chandler, K., "Emissions from Trucks and Buses Powered by Cummins L-10 Natural Gas Engines,” SAE Paper 981393. 